$$
\text { UNIVERSIDADE DE SÃO PAULO }
$$

ESCOLA DE ENFERMAGEM

\title{
EXPERIÊNCIA DE TORNAR-SE MÃE NA UNIDADE DE CUIDADOS INTENSIVOS NEONATAL
}

MONIKA WERNET

São Paulo

2007 
MONIKA WERNET

\section{EXPERIÊNCIA DE TORNAR-SE MÃE NA UNIDADE DE CUIDADOS INTENSIVOS NEONATAL}

Tese apresentada à Escola de Enfermagem da Universidade de São Paulo, para a obtenção do título de Doutor em Enfermagem.

Orientadora: Profa. Dra. Margareth Angelo

São Paulo

2007 
Pelo amor ao meu filho Gabriel. 


\section{Agradecimentos}

À Deus por oportunizar-me vivências ímpares e fortalecer-me nos momentos mais difíceis. Só ele sabe o contexto adverso que enfrentei para concluir. Obrigado por manifestar-se fazendo do sofrimento uma força propulsora...

Rogério, Klaus e Mãe, vocês são pessoas muito especiais da minha vida. Dentro do possível e impossível eu tenho vocês sempre ao meu lado. Obrigada.

Pai, ainda estou aprendendo a estar contigo de forma diferente... Vou sentir saudades da sua torcida, do seu beijo, do seu abraço, do seu parabéns... ... sei que fará tudo isso mas, sinto falta.

Aline, você foi uma nova amiga conquistada durante os anos de doutoramento. Nossa amizade extrapolou a sala de aula. Hoje Ihe considero uma das minhas melhores amigas. Obrigada por tudo que fez e faz por mim. Divido com você a alegria desta conquista.

A Escola de Enfermagem da Universidade de São Paulo pela oportunidade de concluir o estudo.

Aos vários docentes da Escola de Enfermagem da Universidade de São Paulo com os quais tive a oportunidade de ser aluna e ampliar meus saberes.

Aos funcionários da Escola de Enfermagem da Universidade de São Paulo, em especial aos da Secretaria de Pós-Graduação pela pronta disponibilidade e apoio. 
Ao Centro Universitário São Camilo por apoiar-me nesta caminhada, em especial na pessoa da Profa. Dra. Luciane Lúcio pela prontidão ao meu apelo.

Aos colegas de docência do Centro Universitário São Camilo pela torcida e incentivo para eu continuar. Obrigada Marlise, Raquel, Gabriela e Márcia Romero por oferecerem, com muito carinho, um pronto apoio.

Aos hospitais que concederam o espaço para a realização da pesquisa.

Às mães pela confiança em compartilharem suas experiências comigo, tornando possível a realização deste estudo

Sou muito grata a todos. 


\section{Agradecimento especial}

Professora Dra. Margareth Angelo, talvez não tenha sentido o quanto confio e acredito na sua pessoa. Posso Ihe afirmar que sempre estive próxima de você, em função de constantemente retomar em minhas reflexões de vida suas observações, seus textos, suas aulas, seus comentários, seus ensinamentos de vida... ...aprendi muito por toda a seriedade e compromisso com que conduz o que se propõe a fazer. Sua presença na minha história foi muito importante. Obrigada pela oportunidade. 


\section{SUMÁRIO}

\section{RESUMO}

ABSTRACT

RESUMÉN

APRESENTAÇÃO

Motivação para o tema

PARTE I - PROBLEMÁTICA E LOCALIZAÇÕES TEÓRICO

METODOLÓGICAS

1.1 A parentalidade do prematuro na UCIN: funcionamento

familiar e representações simbólicas

1.1.1 Família, prematuridade e hospitalização

1.1.2 Funcionamento familiar e representação da parentalidade

1.2 O Interacionismo Simbólico e a pesquisa de narrativas

1.2.1 O Interacionismo Simbólico: referencial teórico

1.2.2 A pesquisa de narrativas: referencial metodógico

1.3 Fatores constitutivos de pesquisa

1.3.1 Local da pesquisa

1.3.2 Os sujeitos da pesquisa - um olhar sobre a representação identitária

1.3.3 Aspectos éticos

1.3.4 Coleta de dados: a entrevista em seu meio estruturante

1.3.5 Análise dos dados: a análise das narrativas com

55 abordagem holística temática

\section{PARTE II - APRESENTACÃO DOS RESULTADOS}

2.1 Tema: Sentir responsável pelo filho

2.2 Tema: Proteger o filho

2.3 Tema: Aprender

2.4 Tema: Sentir-se mãe

PARTE III DISCUSSÃO DOS RESULTADOS

Discussão dos resultados

REFERÊNCIAS 
Wernet M. Experiência de tornar-se mãe na Unidade de Cuidados Intensivos Neonatal. [Tese]. São Paulo (SP): Escola de Enfermagem da Universidade de São Paulo; 2007. 134p.

\section{RESUMO}

O nascimento prematuro e a hospitalização do filho na Unidade de Cuidados Intensivos Neonatal (UCIN) determina à mulher vivenciar a experiência de tornar-se mãe em um contexto adverso. A maioria dos estudos de enfermagem explora a experiência da mãe na UCIN, e poucos são os que focam a parentalidade. A presente pesquisa visa contribuir nesse âmbito a partir da descrição da experiência da mulher de tornar-se mãe quando vive a estada de seu filho prematuro na UCIN. A pesquisa de narrativa foi estratégia metodológica selecionada em função de possibilitar a extração, análise e compreensão de histórias pessoais vividas. Este estudo analisou a narrativa de doze mulheres e, pautou o processo analítico no referencial teórico do Interacionismo Simbólico. Foi possível estabelecer uma narrativa tradutora da experiência a partir de três grandes núcleos temáticos vividos na UCIN: PROTEGER O FILHO, APRENDER E SENTIR-SE MÃE. Os mesmos traduzem intenções, sentimentos, ações e estratégias integrantes da experiência e, são influenciados pelo núcleo temático SENTE-SE RESPONSÁVEL PELO FILHO, relativo ao período gestacional. Os aprendizados são elementos fundamentais do processo por apoiarem a mulher na determinação do como fazer para se inserir e ser presente junto do filho. Os conceitos desvelados pelo estudo permitem a revisão de práticas clínicas de enfermagem e sinalizam para a necessidade de pesquisas de enfermagem neste âmbito.

Palavras-chave: Prematuro; Relações mãe-filho; Enfermagem neonatal; Terapia intensiva neonatal. 
Wernet $M$. The experience of becoming a mother in the Neonatal Intensive Care Unit. [Tese]. São Paulo (SP): Escola de Enfermagem da Universidade de São Paulo; 2007. 134p.

\section{ABSTRACT}

The premature birth and the sun's hospitalization in the Neonatal Intensive Care Unit (NICU), impose women to experience becoming a mother in an adverse context. The majority of nursing studies explore the mother experience in the NICU, only some studies focus on parenthood. The present study aim to collaborate in this aspect, describing the experience of women in becoming a mother when their premature sun is hospitalized in the NICU. Narrative research was the methodological strategy option as it provides the opportunity to extract, to analyze and to comprehend personal lived stories. This study explored the narratives of twelve women, and structured the analytic process on the theoretical reference of Symbolic Interactionism. It was possible to establish an integrative narrative of the experience of becoming a mother through three core themes: TO PROTECT THE SUN; TO LEARN and TO FEEL AS A MOTHER. The themes represent intensions, actions, feelings and strategies adopted by mothers and are influenced by the theme FEELING RESPONSIBLE FOR THE SUN, which is related to the pregnancy period. The knowledge gained through out the process are fundamental aspects as they support women to manage their way of how to be present and how to do things for their sun. The concepts revealed in the study allowed the review of clinical practices in Nursing and point out the necessity of nursing research in this area.

Key words: premature; mother-child relationships; Neonatal Nursing; Intensive Care, Neonatal. 
Wernet M. Experiencia de ser madre en la Unidad de Terapia Intensiva Neonatal. [Tese]. São Paulo (SP): Escola de Enfermagem da Universidade de São Paulo; 2007. 134p.

\section{RESUMEN}

El nascimiento prematuro y la hospitalización del hijo en la Unidad de Terapia Intensiva Neonatal (UTIN) lleva a la mujer a vivenciar la experiencia de convertirse em madre en un contexto adverso. La mayoría de los estudios de enfermería explora la experiencia de la madre en la UTIN, y pocos son los que enfocan la maternidad. Esta investigación busca contribuir en este ámbito a partir de la descripción de la experiencia de la mujer al convertirse en madre viviendo la estadía de su hijo prematuro en la UTIN. El análisis de la narrativa fué la estratégia metodológica seleccionada por permitir la extracción, análisis y compreensión de las histórias personales vividas. Este estudio analisó la narrativa de doce mujeres y describió el proceso analítico en el referencial teórico del Interaccionismo Simbólico. Fué posible establecer una narrativa traductora de la experiencia a partir de tres grandes núcleos temáticos vividos en la UTIN: PROTEGER SU HIJO, APRENDE Y SE SIENTE MADRE. Los mismos traducen intenciones, sentimientos, acciones y estratégias integrantes de la experiencia y son influenciados por el núcleo temático SE SIENTE RESPONSABLE POR EL HIJO, relativo al período de gestación. Los aprendizajes son elementos fundamentales del proceso por apoyar a la mujer en la determinación de como hacer para inserirse y estar presente junto al hijo. Los conceptos descubiertos por el estudio permiten revisar prácticas clínicas de enfermería y señalan para la necesidad de investigación de enfermería en este tema.

Palabras clave: Premature; Relaciones madre-hijo; Enfermería neonatal, Cuidado intensivo neonatal. 
APRESENTAÇÃO 


\title{
MOTIVAÇÃO PARA O TEMA
}

\begin{abstract}
" O assunto família envolve a todos, uma vez que vivemos nela e estamos em contato com suas mudanças e com as dificuldades que estas nos trazem." (Coelho, 2006)
\end{abstract}

Nos anos dedicados ao Mestrado, fui formalmente apresentada aos pressupostos da filosofia de cuidado centrado na família, na qual esta é concebida como unidade de cuidado, com o reconhecimento do impacto exercido pelas vivências de cada membro na unidade como um todo.

Reconhecer a família como unidade de cuidado, e, conseqüentemente, de responsabilidades do enfermeiro foi um processo construído ao longo de minha trajetória profissional como enfermeira. Inicialmente, o fiz de forma não consciente, por meio de reflexões e desconfortos frente ao não reconhecimento, por parte de outros profissionais, da experiência da família na situação de doença da criança. Posteriormente, percebi na prática clínica, uma atenção de minha parte às preocupações familiares, estimulando sua verbalização, ainda que eu não soubesse, nesse momento, como direcionar essa ação de ouvir para um fazer que contribuísse para o enfrentamento das situações por parte da família.

O interesse em aprender a compreender e ajudar as famílias estava presente, desencadeado por um sentimento de compromisso, compaixão e solidariedade. Relacionava-me com elas e fazia diferença em suas vivências. Faltava-me, no entanto, respaldo de conhecimentos teóricos para intervir de forma mais elaborada e centrada nas demandas manifestas. Ainda assim, pude perceber nas diferenças de significações e expectativas entre mães, pais, família e enfermeiros, a existência de um descompasso. O descuidado é o resultado derivado deste descompasso, 
onde nem a família sente-se cuidada e nem o enfermeiro sente que cuidou desta.

Interessei-me em ampliar minhas competências e, nos anos do Mestrado, tive a oportunidade de adquirir, ampliar e aprofundar conhecimentos para o cuidado de famílias. Fui apresentada pela primeira vez à especialidade de Enfermagem da Família, seus pressupostos e suas preocupações, identificando-me com suas questões essenciais. Entendi o processo por mim vivido como enfermeiro, que culminaria, por meio do desenvolvimento de minha dissertação de mestrado ${ }^{1}$, na consciência de que a família constitui unidade a ser cuidada pelo enfermeiro. Nesta pesquisa, evidenciei a transformação dos conceitos de cuidar e de família à medida que o enfermeiro aproxima-se das pessoas no cenário de assistência, pois, ao reconhecer a criança como pessoas e, por meio dela, a importância de sua família, passa, de um cuidado focalizado no indivíduo, para um cuidar no qual a família é integrada como unidade a ser cuidada, com o desenvolvimento de ações individualizadas para as necessidades emergentes. Hoje percebo o quão amplo e complexo é o cuidado às famílias por englobar, dentre outros elementos, habilidades e conhecimentos, por parte dos enfermeiros, específicos a esse âmbito de atuação; compreensão dos aspectos interacionais entre os membros familiares expressos no seu funcionamento, derivados da história da família e de suas famílias de origem; acurácia na escuta, etc. Elementos que são desvelados aos poucos e apenas em interações profissionais promotoras e capazes de capturar tais manifestações.

Os conceitos e reflexões derivados desta contínua sensibilização e busca de elementos teóricos para questões envolvendo experiências familiares só foi aguçando o processo de pensar família, seja frente a minha própria vivência familiar, seja na partilha das vivências de famílias em situação de hospitalização infantil e neonatal, contexto esse presente

\footnotetext{
${ }^{1}$ WERNET M. Mobilizando-se para a família: dando um novo sentido ao cuidar e à família. 2001. São Paulo: Dissertação (Mestrado) Escola de Enfermagem da Universidade de São Paulo, 105p.
} 
nas minhas práticas profissionais como docente. Pensar família foi mediada pelo partilhar de aulas teóricas, leituras e comentários partilhados pela Profa. Margareth Angelo.

Ampliava-se continuamente meu interesse em compreender a família e seus processos organizatórios, bem como o desejo de ter conhecimentos e habilidades para auxiliá-las na busca dos seus ideais, do seu bem-estar.

Na época do Mestrado, fui também apresentada ao Interacionismo Simbólico e aos pressupostos para o cuidar de Milton Mayeroff, quando reconheci a importância da interação nas situações de cuidado, com destaque para a presença de aspectos que favoreçam aproximação, reciprocidade, confiança e respeito. Esta forma de estar conecta-se a elementos emergentes do interior de cada indivíduo, os quais exercem impacto na relação apenas na real existência do desejo de expressá-los. Trata-se de uma forma de estar que tem na opção de importar-se com o outro, com as famílias, a força promotora de uma relação com maior probabilidade de ser concebida como de cuidado, ou seja, de ocorrer oferta de ações e atitudes congruentes com as necessidades manifestas.

Ao direcionar olhares e reflexões para o cenário da prática clínica de enfermagem, identifico o descaso dado à abordagem centrada na família, o que é, na minha concepção, reflexo da pouca valorização, pelos enfermeiros, dos pressupostos que a sustentam. Dentre outros fatores responsáveis por influênciá-la, essa situação vincula-se sobretudo aos processos de formação do enfermeiro, tanto no âmbito de graduação quanto no de pós-graduação lato sensu, em que se trabalham, de forma incipiente, crenças, valores e conteúdos promotores de mudanças de paradigmas relacionados ao cuidado reconhecedor da família como unidade.

Nas especialidades da Enfermagem Pediátrica e Neonatal, conceitos vinculados à família e sua importância para a criança prevalecem com 
uma tônica voltada à sua participação no cuidado da criança, com transferência de responsabilidades da Enfermagem às famílias. No entanto, a experiência da família, a repercussão da situação de doença e de hospitalização da criança sobre o sistema e os papéis familiares, são pouco valorizados, de modo que a família, apesar de fazer-se presente nos cenários de cuidado pediátricos, com interação, participação e atribuição de significado à situação vivida, é pouco acessada, compreendida e acolhida nas suas demandas. As intervenções, norteadas por uma abordagem centrada na doença ou na criança, limitam-se, na maior parte das vezes, a reconhecer o espaço do hospital como cenário de atuação junto das famílias, e, a ter no preparo para a alta hospitalar, com ênfase para o cuidado da criança, por meio de treinamentos de como manipular dispositivos tecnológicos ou lidar com limitações da criança, o grande eixo colaborativo entre enfermeiros e famílias.

A assistência à família requer a integração do conhecimento de seu funcionamento como unidade familiar, com peculiar atenção às suas crenças, processos de comunicação, facilidades, dificuldades e esforços para o manejo da situação adversa vivida. A representação dos papéis assumidos pelos representantes familiares deve ser objeto de atenção do enfermeiro, uma vez que podem estar neste âmbito entraves para o funcionamento familiar. Estes saberes tendem a propiciar uma presença profissional promotora de um cuidado colaborativo entre enfermeiros e famílias.

Cabe ressaltar que as contribuições das pesquisas de Enfermagem exploradoras da experiência da família na Unidade de Cuidados Intensivos Neonatal (UCIN) ocorrem de forma a caracterizar o impacto da prematuridade e hospitalização na UCIN, exploradas na perspectiva de um membro da família (predominantemente a mãe), e sinalizam o sofrimento e esforço familiar para adequar-se à situação e sentir-se conectada à criança que se encontra na UCIN. 
Compreender as repercussões da prematuridade e hospitalização do filho em uma UCIN sobre o processo da parentalidade na UCIN é pouco abordado e constitui-se o objeto da presente pesquisa, que visa a ampliar os saberes disponíveis relacionados à questão e contribuir para a mudança de paradigmas envolvendo as qualidades atribuídas a ser pai/ ser mãe..

Estudo desenvolvido na Austrália( ${ }^{(1)}$ abordando esta temática afirma serem as expectativas relacionadas ao o que congrega a qualidade de "boa mãe" divergentes entre enfermeiros e mães, residindo neste aspecto implicações para o bem-estar materno e para o cuidado do recém-nascido (RN) na UCIN. Adiciona existir uma maior facilidade no processo de tornar-se mãe nas mulheres que estabeleceram junto aos enfermeiros um relacionamento positivo, o que mostra que a mulher se torna mãe em um contexto público, sob o crivo do olhar da família e de profissionais.

Outro estudo(2) aponta estarem, as interações entre mãe e profissionais da UCIN, pautada na oferta de informações às mães, com escassos momentos de diálogo, ou seja, de momentos onde o processo da comunicação é vivenciado com trocas bilaterais.

Como se vive a experiência de maternar neste contexto?

Com o compromisso de favorecer a transição e o exercício pleno do papel de mãe na estada da mulher com seu filho prematuro na UCIN, surgiram-me várias inquietações: é possível sentir-se plenamente mãe no contexto da UCIN? Se sim, o que está atrelado a esse sentimento? A conexão com o filho tem características diferentes quando vividas na UCIN? Que elementos fazem-se necessário para a expressão da maternagem neste ambiente? Em que momento ela começa a ser sentida?

Com estas inquietações, realizei a leitura de artigos relativos à experiência da mulher/ mãe na UCIN e fui ficando sensibilizada para os momentos iniciais de sua trajetória neste contexto, entendendo ser ele muito crítico e de grande esforço físico, mental, emocional e espiritual 
para a mulher garantir-se como pessoa e expressar-se em suas necessidades. Decidi por restringir minha pesquisa a este momento e estabeleci como pergunta norteadora "como se processa a experiência de tornar-se mãe de um prematuro com necessidade de estada na UCIN nos momentos iniciais da experiência". Concebi como momentos iniciais da experiência aqueles nos quais a mulher ainda não consegue sentir-se calma e com certo controle diante do processo da prematuridade com necessidade de cuidados intensivos neonatais. Focalizo a atenção, portanto, aos momentos nos quais o desespero, a inquietação, o grande sofrimento ainda são os condutores do enfrentamento. É um período ao qual se dá pouca atenção e por mim entendido como delicado em função da possibilidade de um maior descompasso na interação entre mães e profissionais.

Corrobora com minhas preocupações e compromisso com famílias vivendo a prematuridade com necessidade de estada em uma UCIN o fato de eu ter experienciado, no último ano do doutorado, ser mãe de um prematuro com necessidade de UCIN por 30 dias. Dentre diversas reflexões e aprendizados, identifico o quão complexo é integrar um novo papel ao cotidiano familiar. Em outras palavras, tornar-se mãe, pai e outros papéis oriundos do nascimento de uma criança repercutem intensamente na dinâmica familiar e são vividos com pouco diálogo sobre as expectativas, sobre os rearranjos necessários nas relações e as prioridades familiares. Essa ausência pode culminar em divergências importantes que são, no momento inicial, acobertadas pela tolerância entre os membros, com a crença de se poder estar privilegiando o bemestar do companheiro(a) para a expressão do seu papel junto à criança. Percebi o quanto há a necessidade de se compreender a integração de novos papéis, os quais precisam ser dialogados enquanto expectativas e ações no coletivo da família. Ao dividir com outras mães momentos de grande sofrimento na UCIN e a necessidade de controlar-me na luta pela maternagem, quantas vezes não fui acolhida por mães que me 
mantiveram sentindo-me mãe? Vivenciar essas experiências ampliou minha sensibilização ao tema: o tornar-se mãe na UCIN é uma experiência desafiadora e precisa encontrar um contexto mais propício, para que o equilíbrio seja restabelecido.

A par da pouca literatura a respeito da temática na Enfermagem, principalmente com um enfoque no momento do início desta trajetória, a presente pesquisa, além de anteriormente apontado, tem por objetivo contribuir com fundamentações que propiciem uma prática de Enfermagem Neonatal reconhecedora da família como unidade de cuidado, bem como colaborar com as diversas famílias que venham a viver esta experiência.

Para tanto, o referencial teórico selecionado foi o Interacionismo Simbólico, cujo enfoque encontra-se nas interações e nos processos de construção de significados e ações. Como referencial metodológico adotou a narrativa temática, por compreender estar no contar das histórias o desvelar dos aspectos envolvidos com a experiência de tornar-se mãe. 
Parte I

\section{Problemática e}

Localizações teórico metodológicas 


\subsection{A PARENTALIDADE DO PREMATURO NA UCIN: FUNCIONAMENTO FAMILIAR E REPRESENTAÇÕES SIMBÓLICAS}

\subsubsection{Família, prematuridade e hospitalização}

Na Enfermagem Neonatal identificam-se, principalmente a partir da década de 90, pesquisas que buscaram compreender a experiência da família frente à internação de um filho na UCIN, com ênfase na perspectiva materna. Os resultados dessas pesquisas apontam para o fato de, inicialmente, a família deparar-se com as repercussões de significações resultantes, de um lado, do impacto do ambiente da UCIN, de outro, do aspecto do filho prematuro, relacionando-se preocupações ao risco de seqüelas e morte do bebê e ao receio e concepção de despreparo para assumir os cuidados peculiares que esse filho exige. Processos interacionais vividos na UCIN podem auxiliar na familiarização e integração entre o ambiente e criança, bem como na aquisição de conhecimentos e habilidades para negociar uma crescente participação no contexto cujo objetivo é tornar-se mãe/ família do prematuro.

Gomes $^{(3)}$, ao estudar as repercussões da hospitalização do recémnascido na família, verificou que a mulher pode não conseguir viver seus diferentes papéis sociais, o que repercute em conflitos e desagregação entre os membros da família. Lamy ${ }^{(4)}$ enfatiza ser o cuidado da mãe uma tecnologia que deve ser incorporada nos contextos neonatais. Por fim Scocchi ${ }^{(5)}$, também sinaliza para uma prática em unidades neonatais que está sendo substituída por um modelo fundamentado no processo saúde- 
doença-cuidado, cujo objetivo seria uma assistência integral, humanizada e preventiva.

Os resultados das pesquisas exploradoras da experiência da família na UCIN podem ser organizados em três grandes eixos de atenção: o impacto da prematuridade, o comportamento familiar e núcleos colaborativos.

\section{O IMPACTO DA PREMATURIDADE}

Esta temática aborda as conseqüências iniciais da prematuridade sobre os planos familiares, em que se destaca o confronto entre o idealizado e o vivido.

Os estudos são unânimes em apontar que a chegada prematura do bebê rompe com os anseios familiares em relação ao filho, primeiramente por impor a sua separação. Essa precoce separação constitui-se na primeira crise familiar, restringido o contato pais/ filho ansiosamente esperado ao longo da gestação. Não poder pegar o filho no colo impõe uma interação, marcada pela ausência ou pela minimização do contato físico, à qual soma-se a mediação de aparatos tecnológicos (3,6-7-8-9-10-11-1213-14-15-16-17-18-19). Reflexo desse contexto interacional são os seguintes conceitos: os prematuros são crianças frágeis e com risco de vida iminente ${ }^{(3,6-7-8-9-10,13,15-16,18)}$ que podem ficar com seqüelas após saírem da $\operatorname{UCIN}^{(8,13)}$; a UCIN é um local de risco de vida com grande probabilidade de morte, onde as crianças lutam entre o viver e o $\operatorname{morrer}^{(3,}$ 7-8-9-10, 15).

Observa-se assim que, não sendo inicialmente as perspectivas boas, vivem-se repercussões desses significados no comportamento materno e familiar, visto que se evita o apego em função da concepção de uma probabilidade antecipada de perda do bebêt $\hat{e}^{(3,7-8-9-10,15)}$. 


\section{O COMPORTAMENTO FAMILIAR}

Frente às concepções de prematuro e UCIN, a família encontra-se, em um primeiro momento, na incerteza de que o prematuro sobreviverá, principalmente pelas observações que desenvolve ao longo de sua permanência na UCIN e visitas feitas. O ambiente repleto de aparelhos, a pequeneza dos bebês, a agitação das pessoas, impactam a família de forma a inibi-la olhar e tocar em seu bebê $\hat{e}^{(6-7-8,10-11-12-13-14-15-16-17,19-20-21)}$.

Neste momento, prevalece observar e centrar-se nos aspectos negativos do ambiente, aqueles reforçadores da possibilidade de perda e gravidade do bebê, o que repercute em uma pequena abertura para a vinculação com o filho e com outras pessoas. Por meio da observação atenta do ambiente (lugar, equipamentos e pessoas) a mulher volta-se para a obtenção de evidências de que a sobrevivência de seu bebê é uma probabilidade real $\left.{ }^{6}, 9-10-11-12,15-16,21\right)$. A sensação de impotência e angústia diante desse ambiente corrobora para a prorrogação do processo de estreitamento dos vínculos da mãe com seu bebê(8-9-10, 13, 15-16, 21-22-23).

O processo de vinculação está diretamente relacionado aos sentimentos em relação ao bebê e à situação( ${ }^{(8-9,17,22-23)}$. Apenas com a estabilidade progressiva da criança e a identificação de que a sobrevida é possível, a alegria e a sensação de superação passam a ser sentimentos presentes, com favorecimento e sedimentação da esperança. A esperança é o sentimento que mobilizará todo o processo de maternagem e de vínculo $^{(8-9,15)}$ a ocorrer. Acreditar na sobrevivência do bebê mobiliza a procura da fé para vencer sentimentos de medo e insegurança, para encontrar a esperança e a força que, auxiliando nos momentos difíceis, conduzem à busca de estratégias que favoreçam a participar e acreditar na recuperação e na sobrevivência do filho ${ }^{(9,15)}$. 
" A primeira estratégia, ou a estratégia possível, para os pais é dar prioridade à criança, deixando tudo e fazendo o sacrifício necessário para garantir a vida... O amor pelo filho leva os pais a dar prioridade à vida e ao bem-estar dele (14, $^{(14)}$ p.94)."

No exercício da maternagem, ocorre o desejo de exercer ações cuidativas junto do filho ${ }^{(7-8,15,17)}$, a fim de garantir o atendimento de suas necessidades para que o crescer e desenvolver-se bem se concretizem $^{(15-16-17)}$.

Os pais colocam-se disponíveis e dispostos a agir e ficar perto do filho ${ }^{(14,17)}$. A segurança emocional para o exercício pleno do cuidado, por parte da mãe, é alcançada por meio de perguntas e observações nas interações vivenciadas com a equipe de assistência, principalmente com a da enfermagem ${ }^{(2,11,16-17)}$.

Uma das manifestações mais presentes de ser mãe são as ações de proteção ao filho ${ }^{(15-16-17)}$, o que resulta sempre em uma sobreposição da necessidade do filho sobre a da mãe. Estudos revelam, justamente, que algumas mães deixam de estar presentes na UCIN ao identificarem que a equipe de assistência a julga como impertinente e chata, e ao perceberem que na sua ausência o filho é melhor cuidado(15-16-17). Ser impedida de realizar os cuidados do filho e ter que permitir que outros o façam é um sofrimento para os pais ${ }^{(16-17)}$. Outro aspecto que deixam os pais apreensivos é a identificação da inadequação na relação enfermeiro/crianças, o que intensifica ações de vigilância ${ }^{(17,23)}$.

A atitude de vigilância é manifestação da maternagem. A mulher busca a compreensão das intervenções e ações profissionais desenvolvidas junto ao filho, bem como os pontos de divergências na condução das mesmas. Observar, comparar e questionar constituem-se em manifestações comportamentais dessa vigilância ${ }^{(17,23)}$. 
Portanto, nos comportamentos maternos, podemos identificar por meio dos estudos dois núcleos de intenção: inicialmente a busca de evidências de que o filho sobreviverá e, posteriormente, a busca pelo espaço para prover cuidado ao filho, visando ao atendimento de suas necessidades. Em ambas as situações, observações, comparações e questionamentos são ações por meio das quais a mulher estabelece a busca dos fins almejados. Tentam sempre serem vistas pelos enfermeiros como adequadas $(14,17,23)$.

\section{NÚCLEOS COLABORATIVOS}

Estudos identificam que a natureza das necessidades maternas em uma UCIN está centrada em dois grandes processos: o da comunicação/ informação(14, 16-17-18-19) e o de apoio/suporte ${ }^{(14,17-18)}$.

O primeiro aponta a necessidade de obtenção de informações para a compreensão da situação vivida pelo filho, ao longo de toda a trajetória de permanência na UCIN.

O segundo traz a necessidade de uma rede de apoio (pai, outras mães, profissionais da saúde, suporte social, espaço para ser ouvida) para transpor as demandas de tornarem-se mães de bebês que estão na UCIN.

A comunicação efetiva é um recurso primordial para o alcance destas demandas maternas ${ }^{(18)}$. A equipe de assistência, sendo o elemento que está na vivência da mãe, recém-nascido e famílias na UCIN, deve atentar-se para a forma de agir, buscando oferecer uma presença que facilite os processos vividos pelos pais/ família. Muitos estudos que exploraram o processo de enfrentamento destacaram as interações com os profissionais da saúde, principalmente a enfermagem, como promotoras da resiliência dos pais ${ }^{(6,8-9-10,15-16-17-18-19-20-21,23)}$. 
O apoio intergeracional, com destaque para os avós e amigos, são

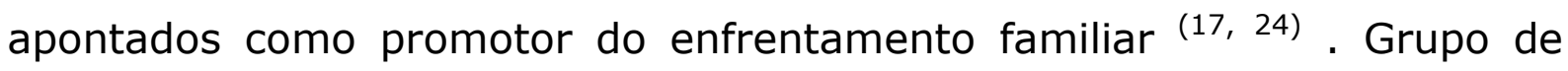
pais é apresentado como pouco efetivo(24).

A incongruência de significados e expectativas na interação dos pais com os profissionais que atuam nas UCIN resulta na falta ou reconhecimento tardio das necessidades familiares $(9,14,16-17-18,23)$, o que ocasiona o surgimento de conflitos de informações e orientações ${ }^{(16-17,23-24)}$ e, conseqüentemente, o favorecimento da ansiedade, tensão e estresse.

A confiança dos pais na equipe de profissionais está atrelada a alguns fatores: esclarecimentos e informações ofertadas, linguagem adotada, atenção dispensada, acolhimento e convívio. Os profissionais, muitas vezes, não vêem a necessidade de os pais tocarem no bebê, dão pouca atenção à ansiedade observada, faltando-lhes o conhecimento referente ao apego mãe-filho, à importância das relações interpessoais, ao conhecimento disponibilizado pela especialidade Enfermagem da $\operatorname{Família}^{(9}$, $14,17,21-22-23)$

A atitude do enfermeiro de compartilhar decisões reconhece a diferença de interpretações por parte das mães e profissionais, não se restrigindo, no entanto, a julgamentos. O foco concentra-se no processo de conhecer e entender como as mães percebem a situação vivida ${ }^{(11,16,}$ 22), retratar interesse, ter paciência ${ }^{(23)}$, modo de ação para os quais o escutar é primordial (22-23). As mães querem ser escutadas, querem identificar na escuta a disposição e interesse para serem ouvidas ${ }^{(9,22-23)}$.

Sentir o carinho dos profissionais proporciona sensações de bemestar e facilita as adaptações necessárias ${ }^{(10-11,16)}$, enquanto que posturas de mando/ordem inibem a abertura para a relação ${ }^{(23-24)}$. Estas últimas instigam na mãe atitudes de proteção, em que emoções são contidas e reflexões acerca das conseqüências de suas ações passam a ser continuamente ponderadas, causando a auto-repreensão, por vezes, a retirada física do espaço ${ }^{(17,23)}$. 
A mãe percebe-se partilhando com o filho a atenção e as ações do mesmo profissional e, por isto, sente-se competindo com ele pelo cuidado $^{(14,16-17)}$, o que resulta em cautela na expressão de suas necessidades $^{(16-17,21)}$, chegando, por vezes, a não manifestá-las ${ }^{(17)}$.

É importante salientar que a resposta materna frente à experiência de ter um filho na UCIN tem diferenças em relação à experiência paterna $^{(9,22)}$, sendo, provavelmente também diferente da experiência da família como unidade. Estes últimos objetos de pesquisa podem vir a colaborar com a consolidação de um corpo de evidências científicas para a prática clínica junto às pessoas e famílias, sujeitos que vivenciam o evento de ter um prematuro na UCIN.

Concordo que um dos grandes desafios dos enfermeiros neonatologistas consiste no conhecimento de como prover cuidados que atendam as necessidades da mãe e crianças $^{(12)}$ e identifico que as pesquisas disponíveis já se encontram relativamente estruturadas nesse âmbito.

Precisamos colocá-las em prática e reconhecer a família como capaz de enfrentar seus momentos de dificuldade, como capaz de encontrar soluções próprias, necessitando ter suas forças reconhecidas.

As forças familiares são suas competências e seu potencial em buscar estratégias para aumentar sua capacidade em superar as dificuldades e em transpor ou resistir ao estresse presente em crises ao longo de seu existir. Traduz o encontro de recursos para lidar com os desafios atuais e futuros ${ }^{(25)}$, direcionando-se para reflexões sobre o modo pelo qual a mulher/mãe, inserida no contexto familiar, estrutura e vive a construção de seu papel de mãe na situação de hospitalização de um filho na UCIN.

O significado da adversidade depende de transações familiares. As famílias são mais capazes de enfrentar a adversidade quando a 
mutualidade faz-se presente, com o reconhecimento de que todos os membros familiares estão fazendo o melhor que podem dentro de seus limites particulares ${ }^{(25-26)}$. Será que no processo de tornarem-se mães na UCIN as mulheres encontram isto?

\subsubsection{Funcionamento familiar e representação da paternidade}

"... não existe nenhum estágio que provoque mudança mais profunda ou que signifique desafio maior para a família nuclear e ampliada do que a adição de uma nova criança ao sistema familiar" (Bradt, 1995)

Os estágios do ciclo vital familiar são descritos por vários autores. Adotamos a proposta descrita por Carter e McGoldrick ${ }^{(27)}$, que propõem e descrevem seis estágios de ciclo de vida das famílias americanas de classe média.

No estágio famílias com filhos pequenos, uma das tarefas a ser incorporada ao funcionamento da família é cuidar dos filhos, quando responsabilidades e papéis necessitam ser revistos e acordados.

O evento da prematuridade e hospitalização na UCIN causa impacto no sistema familiar e exige a revisão dos processos interacionais e de funcionamento da família, a fim de viabilizar a sua administração. Identificar e definir como é co-construído e o que é concebido como problema/ necessidade para a família nesse contexto, compreender a participação dos profissionais e a da instituição pode estabelecer princípios e pressupostos que conduzem a um cuidado mais efetivo. Trata-se de uma contextualização do evento junto às famílias e cenários que o 
contêm, com a intenção de promover processos relacionais que propiciem a auto-organização familiar para a situação vivida.

O sistema familiar, a partir de seu contexto social, econômico e cultural, adota um processo contínuo de seleção, supervisão, avaliação, decisão e acompanhamento da saúde e eventos de doença e hospitalização de seus membros ${ }^{(28)}$.

Nesta manifestação do modo de viver, cada família constituiu seu ambiente, que nas palavras de Scabini apud Althoff ${ }^{(29)}$ é o espaço das relações internas e externas da família. A família é um espaço de vida(30) que, em sua definição e existência, ostenta o contínuo caráter interativo.

Estudando o ambiente familiar, Althoff ${ }^{(29)}$ afirma ser a convivência o fenômeno central que exprime o dinamismo e a singularidade características do processo vivido no mundo interno da família. A autora aponta que a concretização da família com sua própria identidade ocorre com a criação de um espaço para a unidade familiar que, fisicamente, é normalmente representado pela moradia. A moradia delimita o mundo interno e externo, sendo o espaço da construção da história de cada família. Este espaço é dinamizado por meio de interações intra e extra familiares, que retratam o espaço relacional familiar.

" O grau de abertura do espaço da moradia para receber amigos, parentes, vizinhos e outras pessoas indica o quanto os limites são permeáveis e o quanto a família se coloca à disposição para a troca e a ajuda. (29, p. 32)"

O espaço relacional está articulado com outro conceito apresentado por Althoff( $^{(29)}$, o tempo familiar. O tempo familiar não acompanha a trajetória linear dos eventos que caracterizam o ciclo vital, mas é reflexo 
dos processos envolvidos no viver família, relacionando-se e sendo dimensionado pelas mudanças e eventos que, dependentes de estratégias cotidianas e de resolução de problemas, causam impactos.

"A família precisa organizar a vida diária e ordenar as atividades do dia-a-dia de acordo com as condições de que

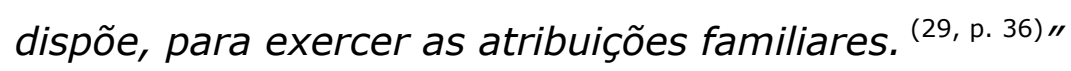

O conceito de tempo familiar embasado nos processos de estabelecimento e fortificação das relações familiares traduz a organização do tempo pela família como recurso para o seu funcionamento. O foco está na identificação da qualidade dos processos familiares ao longo do seu tempo de existência ${ }^{(29)}$.

Este conceito tem sido alvo de pesquisas desde meados de 1990, inicialmente com um enfoque no uso do tempo por cada membro da família e, posteriormente, considerando a família como unidade.

O reconhecimento da importância do tempo para cuidar de relações familiares é primordial, uma vez que, por meio dele, ocorre a construção de estratégias familiares passíveis de aferir resiliência. São características de famílias resilientes: confiança, valorização e afeto entre os membros, processos comunicativos efetivos, bem-estar espiritual, existência de tempo em conjunto e habilidade de lidar com o estresse. O tempo familiar é um elemento importante na construção dos processos familiares de funcionamento.

A família é uma unidade social que constrói um modo de viver que Ihe é próprio, estruturado em crenças e valores que são derivados da história de vida de cada pessoa que a compõe, da história de vida das 
famílias de origem, da história de vida da própria família. Ela tem sua própria cultura que estrutura e fundamenta seu funcionamento.

Os sistemas de crenças familiares proporcionam coerência e organizam a vida, o cotidiano familiar. Nem todas as crenças familiares são partilhadas explicitamente, mas aquelas que são dominantes influenciam intensamente a maneira como a família funciona, principalmente na adversidade. Em contrapartida, as crenças, ao serem partilhadas e desveladas, podem fortalecer a família no enfrentamento do desafio por prover compreensão aos processos familiares adotados para 0 enfrentamento da adversidade ${ }^{(25)}$.

O funcionamento das partes depende do todo e das partes em si. As finalidades e os aspectos do meio envolvente determinam auto-regulação e auto-organização do sistema familiar ${ }^{(25-26)}$. Os processos de informação e comunicação são fundamentais para a coesão(30). A confiança e a comunicação aberta na família são aspectos fundamentais para a resolução de problemas e entendimento mútuo.

Para Angelo ${ }^{(31)}$, a família deve ser entendida como um espaço social e relacional, onde cada evento é vivido a partir dos significados construídos simbolicamente, o que significa que o profissional cuidador necessita de informações decorrentes da dimensão da ação coletiva simbólica e da dimensão de cooperação na solução de problemas. A primeira dimensão acessa dados sobre a interação dos indivíduos entre si e com a situação vivida para identificar os significados que the são atribuídos e as ações individuais presentes. Na segunda dimensão, o foco é a compreensão do processo de interação familiar em direção à solução dos problemas. Assim, os processos interacionais familiares são o fundamento de seu funcionamento, o que valida a afirmação de que o funcionamento das partes depende do todo e das partes em si.

Como observamos, as finalidades e os aspectos do meio envolvente determinam auto-regulação e auto-organização do sistema familiar, sendo 
os processos de informação e comunicação fundamentais para a coesão por proporcionar ajustamento das diferentes partes. Esses processos são atos intencionais com finalidade específica ao sistema familiar e, simultaneamente, representam um mecanismo de regulação social básico ${ }^{(30)}$. Assim, o componente funcional da família se apresenta quando ela se organiza para atender às várias necessidades socioeconômicas: reflete idéias, valores e representações próprias.

"...o processo de comunicação no sistema familiar permite aos seus elementos partilhar o que têm em comum, reduzindo desta forma a incerteza e a ambigüidade, mas também evidenciar as diferenças que os caracterizam. $E$, tanto as semelhanças quanto as diferenças constituem $O$ meio ambiente a partir do qual os indivíduos encontrarão as suas finalidades para se auto-organizarem pessoal $e$ socialmente. ${ }^{(30, p .4) \prime \prime}$

Marcon (32) destaca que a maneira como as famílias encaram seus problemas e opções por elas feitas interferem diretamente sobre o domínio e o enfrentamento da situação adversa. Assim, identificar o processo como uma família lida com situações da vida necessita abarcar, além de informações acerca de quem ela é, também sua rede de relacionamentos, os processos de comunicação presentes, experiências marcantes em sua história, sistema de crenças, padrões organizatórios. Esses dados ampliam a possibilidade de aproximação da realidade familiar, podendo propiciar compreensão de suas escolhas e funcionamento.

$\mathrm{Na}$ vigência de um nascimento prematuro com necessidade de internação junto à UCIN, novas práticas e negociações familiares vão ser incorporadas ao cotidiano das famílias, frente aos significados que aferem 
à sua vivência, fruto de pré-concepções trazidas, e, frente aos novos significados que vão sendo construídos ao longo dela. Um sistema simbólico de representações culturais (mitos, crenças, símbolos culturais) vão determinando regras familiares expressas no seu funcionamento, no exercício dos papéis familiares frente à vivência da parentalidade do prematuro na UCIN.

Assim, tornar-se mãe na UCIN é dependente do funcionamento familiar e dos processos vividos nessa unidade. O conceito mãe e pai e demais papéis advindos do nascimento de uma criança, são trazidos ao cotidiano familiar e retratam o dinamismo do tornar-se cada papel (mãe, pai, avó, dentre outros). O intercâmbio das expectativas e significações construídas ao longo da história de vida pessoal e familiar pode sofrer interferências, de modo que cada membro da família venha a agir e cobrar ações a partir de sua própria perspectiva. Centrando-se no foco da presente pesquisa, a maternagem provavelmente será reflexo do significado de papel de mãe. Em adição, ele certamente é um desdobramento da intersecção do funcionamento da família e da mulher em sua individualidade.

\subsubsection{Construção da maternidade}

A transição para a maternidade é um dos eventos de vida de maior magnitude. A mulher move-se de uma realidade conhecida para uma não conhecida até alcançar a sua identidade materna. ${ }^{(33)}$

Para Rubin (1967) apud Mercer ${ }^{(33)}$, a identidade materna é alcançada quando a mulher se conceitua como estando no seu papel de mãe e integra de forma interdependente o processo de apego ao filho e a formação de sua identidade como mãe. A autora apresenta como outras características do alcance da identidade materna a antecipação de 
comportamentos do filho, conhecendo como, o que, quando e por que ela fará algo por ou com ele como mãe, momento em que ocorre "um situar operacional da criança como 'você', do 'eu' na relação com o 'você', e do 'você' em relação ao 'mim'.

Ao longo do processo de aquisição do papel de mãe, a mulher enfrenta mudanças profundas e fica em situação de vulnerabilidade. Características maternas, do recém-nascido e da família, crenças culturais, preparo e conhecimentos, bem como aspectos do contexto sócioeconômico são as variáveis que influem profundamente nesse processo $^{(33-34)}$.

Segundo estudos de Mercer ${ }^{(33-34)}$, há quatro estágios na transição para a maternidade: (1) antecipatório, momento onde ocorre, em variados graus de intensidade, o preparo antecipado para o papel, com o atitudes de compromisso, vinculação e preparação para a chegada do filho; ele é vivido ao longo da gestação ou até mesmo antes dela; (2) aquisição formal da maternidade, ocorrida com o nascimento, quando a mulher depara-se com a unicidade de seu filho e inicia ações cuidativas seguindo orientações e conselhos de expertise de seu círculo de convivência; há um crescente incremento em seus conhecimentos e habilidades ao longo da interação com o filho; (3) aquisição informal, quando a mulher abandona paulatinamente a rigidez do seguir as orientações e conselhos de expertise e passa a refletir criticamente sobre esses; estabelece-se ao longo dos primeiros quatro meses; (4) neste mesmo período há o alcance da identidade materna, caracterizado pelo senso materno de harmonia, confiança, satisfação no desempenho do papel com laços de vinculação fortemente concretizados; ela sente uma congruência entre seu eu mãe com a performance na maternidade concebida de forma mais coletiva. Tais estágios não são delimitados na experiência da mãe, e sim sobrepostos. Esta mesma autora apresenta algumas observações em relação a cada estágio por nós reorganizadas: 
- Uma boa parcela de mulheres vive o primeiro estágio descrito acima anteriormente à gestação, quando agem para melhorar a situação familiar e garantir boas condições de saúde para si. Assim, há um compromisso com o gestar um bebê saudável, com ações que nutrem o vínculo ao longo da gestação. Os movimentos fetais intensificam o processo entre mãe e filho, sendo comum a existência de projeções sobre a criança;

- Em relação ao segundo estágio, a grande tarefa é a intensificação de contato entre mãe e filho, acarretando aprendizado materno em relação às particularidades de seu filho. O cansaço e repercussões físicas do trabalho de parto e parto à mãe são apontados como um dos eventos que pode interferir no adequado desenvolvimento neste estágio. Esta autora já enfatiza que o tempo necessário para a mãe compreender e aprender a cuidar do seu filho é consideravelmente maior quando a criança é prematura;

- É ao longo do terceiro estágio que a mãe aumenta sua confiança no cuidado do filho e já consolida rotinas familiares que refletem responsabilidades e limites decididos entre os envolvidos;

- Por fim, o prazer proporcionado pela troca e amor estabelecidos entre mãe e filho determinam sentimentos de competência para a mãe, o que culmina no alcance de sua identidade materna no quarto estágio.

Progredir ao longo dos estágios mencionados está sob a influência das experiências de vida abarcadas pela mulher, de características do filho e da criatividade no manejo dos diversos desafios (33-34). As especificidades das características da mulher e do recém-nascido interagem entre si e influenciam-se mutuamente.

Dentre as características maternas influenciadoras do processo são mencionadas a empatia, o autoconceito, a parentalidade concebida, 
flexibilidade, atitudes, experiências de nascimentos, condições de saúde, conflito e força de papéis. Outros aspectos importantes na construção da identidade materna e promotores de seu senso de confiança são o suporte social e o feedback do companheiro em relação a seu desempenho como mãe ${ }^{(35)}$.

No que concerne o recém-nascido, destaca-se o temperamento, a responsividade e comunicação emitida pela criança, bem como as condições de saúde da mesma.

Família e amigos próximos constituem-se no ambiente onde se dão o aprendizado da maternagem e grande parte das influências no processo de tornar-se mãe ${ }^{(34-35)}$.

Em estudo(36) que focou como as mães de prematuros extremos experienciaram emocionalmente o processo de amamentação e a relação com o processo de tornar-se mãe, desde antes do nascimento até a alta da unidade neonatal, identificou-se que os laços sociais modificam-se ao longo do tempo em que a mulher permanece na UCIN. A qualidade desses laços e as alterações emocionais vividas foram apresentadas sob três grandes temas: a "perda" do filho e um caos emocional, colocando "a vida na espera"; a separação que pode conter um sentimento de insignificância como pessoa e mãe; e a tentativa de ultrapassar a limitação de sentir-se uma mãe apenas fisicamente presente.

As mães descrevem igualmente suas experiências de "perder" o seu filho a partir de três aspectos: perda do filho que estava por nascer ("unborn"), acompanhado do sentimento de culpa por não terem experienciado o ultimo período da gestação, não sentir o filho crescer dentro de si e não ter o tempo normal para uma preparação como numa gestação completa, definida como "sendo jogada dentro da paternidade"; "perda" do "filho normal" e perda das "conexões naturais" que as mães de recém-nascidos a termo experienciam; e preparação emocional, por parte de algumas mães, para uma perda possível, por acreditar que o filho pode 
morrer. O seu neonato é colocado em incubadoras, rodeado por equipamentos e profissionais, alertas de bips e monitores. O ambiente sinaliza vida e morte, e o tempo estabelecido pela mães é como se fosse uma ficção travada entre presente e futuro. ${ }^{(36)}$

O parto inesperado e a possibilidade de morte do neonato levam ao caos emocional em que a mãe se sente amedrontada, triste, desapontada, sem valor ou fracassada. Além disso, ela sente que se tornou mãe fisicamente, mas não socialmente ou emocionalmente, algumas por não acreditar na sobrevivência do neonato, outras por não confiar nelas mesmas, não podendo definir seu papel como mãe. Nesse "caos emocional", as mães "colocam a vida na espera", estratégia pela qual elas emocionalmente bloqueiam suas emoções e suportam a situação com uma atitude estóica ("desesperada"). Isto resulta em uma emocional alienação, em relação às suas próprias necessidades pessoais, de seu neonato e de suas necessidades como mãe. ${ }^{(36)}$

A separação entre mãe e neonato é um mediador de insegurança no self e papel materno por duas razões maiores: primeiro porque a separação resulta em sentimentos de sentir-se insignificante para o neonato, sendo vivenciado a conceber-se como apenas uma visita, e segundo porque as necessidades emocionais da mãe de ser íntima para seu filho podem não ser desempenhadas de forma plena ${ }^{(36)}$.

Aspectos críticos do processo de tornar-se mãe, mais que uma "mãe física" incluem: a iniciação da amamentação e do contato pele-a-pele, ações intensificadoras do contato mãe filho; assumir o cuidado, envolvendo negociação com os profissionais e o desempenho do papel maternal; o estado critico de saúde do neonato, que altera as relações sociais $^{(36)}$.

Dessas colocações de corre o questionamento sobre o impacto da prematuridade e hospitalização na UCIN sobre o tornar-se mãe, a partir do qual pretendemos refletir sobre o funcionamento materno nessa 
situação adversa, com atenção para os processos interacionais envolvidos e focalizando aos momentos iniciais da estada da mãe/família neste espaço.

1.2 O INTERACIONISMO SIMBÓLICO E A PESQUISA DE NARRATIVAS

\title{
1.2.1 Interacionismo simbólico: referencial teórico
}

\author{
"Ao tentarmos compreender as \\ interações no processo familiar em direção à \\ solução de problemas, buscamos identificar \\ o processo mental realizado, pois a tentativa \\ de compreender o outro demanda \\ capacidade para ver o significado das \\ palavras e ações dos outros" (Angelo, 1997)
}

Em virtude da necessidade de conhecimento e compreensão dos significados presentes na construção da maternidade quando a mulher vive a prematuridade e hospitalização de seu filho na UCIN, o Interacionismo Simbólico constituiu-se em um referencial teórico condizente. Enfocando o comportamento humano individual e grupal, tem como princípio a compreensão do processo vivido. Ao buscar conhecer os fundamentos e causas das ações humanas. Nesse referencial, o ser humano define e age na situação de acordo com significações ali construídas, significações que emergem na interação social e influem nas atitudes, formas organizatórias e relações intra e interpessoais estabelecidas. O significado atribuído é diretamente relacionado à ação, tanto na sua emergência quanto na influência no contexto interacional ${ }^{(38)}$.

O Interacionismo Simbólico, segundo a concepção de Herbert Blumer $^{(37)}$, tem como premissas: 
- Os seres humanos agem em relação às coisas em função do significado que estas possuem para eles;

- O significado emerge na interação social;

- Os significados são manipulados e alterados pelo processo interpretativo da própria pessoa.

O significado emerge, portanto, na interação e é nela que ocorre a definição da situação, do contexto e dos demais elementos determinantes do comportamento humano. Esse tem sua descrição pautada no ato social por meio do comportamento externado (dimensão da atividade manifesta) e do processo interiorizado (dimensão da atividade interna à pessoa) ${ }^{(37)}$.

O ser humano é ativo na sua experiência, quando, à medida que interage (integração do processo vivido interna e externamente à pessoa), age no presente influenciado pelo o que está passando, aplicando aspectos de um passado vivido(38).

Sendo um ser que interage, interpreta, define e age no contexto de acordo com o significado atribuído às situações vivenciadas ${ }^{(37)}$, pode-se afirmar que é com base na definição gerada no presente da vivência que a pessoa decide suas ações, com influência dos processos significativos do passado e do futuro. Ela cria o significado na experiência. É no presente de cada vivência que ela define ativamente a perspectiva, e, por meio dessa definição da realidade pessoal, desencadeiam-se as ações. As ações são consideradas decisões feitas pelo indivíduo envolvendo definição, interpretação e escolha que estão influenciadas pela relação com o contexto e com o self.

O self é um elemento frente ao qual agimos. É uma entidade social, gerada e mantida no processo de interação, auto-reflexiva, conectada à resolução de problemas, com uma realidade fenomenológica sem localização física ou biológica, composta da fase "eu" e da fase "mim" (38). A fase "eu" tem o próprio indivíduo como sujeito, é a parte mais 
espontânea e impulsiva que reage às atitudes dos outros, não integrando as regras socialmente postas. A fase "mim" é a fase mais social, surge na auto-interação ao pensar, analisar, conversar privativamente consigo próprio, ou seja, tem a pessoa como objeto. Assim, percebemos ser o "eu" o propulsor do indivíduo e o "mim" a fase que permite a incorporação do outro no próprio "eu", direcionando o ato social.

O processo de significação, desencadeado na interação com o self, é comunicado por meio de símbolos às outras pessoas. Os símbolos visam a representação de algo no processo comunicativo. Os objetos ganham sua significação na interação, sendo o que as pessoas indicam $\operatorname{ser}^{(37)}$. Na utilização de símbolos, há a intencionalidade de comunicar algo e seu simbolismo só é atingido efetivamente se este significado intencionado é compreendido por aquele que o produz e por aquele que o recebe ${ }^{(38)}$.

Para entender os significados e as ações dos outros, necessitamos da atividade da mente. A mente, ligada ao self e aos símbolos, emerge no ser humano no mesmo momento em que emerge o self e os símbolos ${ }^{(38)}$. A percepção e a definição ocorrem por meio da atividade da mente e, em resposta à atividade de interpretação aí formada é que agimos.

É por meio da atividade da mente que ocorre a elaboração de significação com posterior ação. É a mente que torna possível o ensaio e a prévia dos atos, definindo-os e redefinindo-os. Toda vez que um objeto chama a atenção do indivíduo, a atividade da mente inicia-se, tentando integrar os símbolos comunicados, a perspectiva do outro e o self, para gerar ações. As ações são desencadeadas por um processo ativo de tomada de decisões pelo sujeito, envolvendo a definição da situação.

Os símbolos têm dinamismo conforme os processos interativos vão acontecendo, e possuem como finalidade representação e comunicação na interação humana ${ }^{(38)}$. 
Outros conceitos importantes neste referencial teórico são o 'assumir o papel do outro', 'ação humana' e 'interação social'.

O assumir o papel do outro é a atividade mental pela qual o indivíduo confere explicação ao que observa, o que the permite alinhar sua ação. Ela inclui um processo que desenvolve o self e que estabelece condição para a interação social e para a comunicação(3).

A ação humana é a capacidade adquirida pelo indivíduo de fazer indicações para si, determinando o como a ação ocorrerá. A ação humana é um reflexo da interação com outros, consigo, e envolve o assumir o papel do outro e o próprio processo interpretativo. Ela é definida no presente, integra experiências passadas, futuras, sentimentos e motivos. Tem nas tomadas de decisão na situação sua grande manifestação ${ }^{(38)}$.

Interação social contém todos os conceitos do Interacionismo Simbólico e inclui o reconhecimento de que, na interação, tornamo-nos objetos sociais para nós e para os outros, usamos símbolos, direcionamos o self através de atividade mental, tomamos decisões na medida em que definimos a situação e assumimos papéis ${ }^{(38)}$.

A interação cria e define o self, ela cria e influencia a habilidade da mente e do assumir o papel do outro. À medida que se vive o processo contínuo da interação social, as pessoas intercambiam coisas entre si e consigo, aferem significações, apreciam e estabelecem perspectivas, realizam tomadas de ação. Cada qual envolvido na interação, enquanto age em relação ao(s) outro(s), intencionalmente comunica-se e passa a ser o que o outro está sendo para si: objeto de interação e propulsor da interação do outro consigo próprio. Assim, a interação social é uma ação social mútua, dialógica, com transmissão de significações simbólicas, instigando o papel do outro, a ação da mente e a interpretação de atos entre si, o que reflete em um processo contínuo de construir a ação ${ }^{(38)}$. 
Retomando a motivação para o presente estudo, a mulher com um filho na UCIN, interage com a "prematuridade", com os elementos da UCIN, com seu contexto, com seus recursos, com a família, com as crenças que detém, significando e determinando ações que repercutem em como ela organiza e age frente às demandas do momento vivido que contém o processo de construção do papel materno, a ação de tornar-se mãe.

Podemos, feitas essas considerações, afirmar que:

- Todo o contexto da UCIN (ambiente físico, pessoas, outras mães, as interações,etc) desencadeia processos interativos e de significação que influem nas tomadas de decisão da mulher no estabelecimento da identidade materna e da maternagem;

- O significado que a família e a comunidade hospitalar aferem ao prematuro, ao papel de mãe manifesto na UCIN, determinam processos mentais na mulher, comportamentos e decisões quanto a sua forma de agir;

- Os significados construídos pela mulher são alterados e revisados nos contínuos processos interativos tecidos na UCIN, no ambiente familiar da mulher e no processo de interação consigo própria;

- Paralelamente às experiências na UCIN, a mulher e sua família continuam agindo para atender as demandas que aparecem ao longo dos seus tempos, sendo necessária a determinação de prioridades maternas, o que influi diretamente no comportamento da mulher como mãe e em suas atitudes maternas ao longo do processo de estar na UCIN;

- A busca de recursos humanos e sociais que promovam a maternidade, dentro da particularidade desta definição para cada família e mulher, é dependente dos significados aferidos pelas 
pessoas aos eventos presentes naquele momento histórico da mulher e da família;

- Os significados construídos pela mulher são revisados e alterados nos contínuos processos interativos tecidos no tornar-se mãe.

Voltando à pergunta norteadora deste trabalho, que busca compreender como se processa o tornar-se mãe de um prematuro com necessidade de estada na UCIN nos momentos inicias da experiência, e considerando, do acima exposto, que os significados construídos pela mulher alteram-se nos contínuos processos interativos tecidos no tornar-se mãe, optou-se, nesta pesquisa, por se fazer uso da pesquisa de narrativa como estratégia metodológica para reconstruir os elementos significativos que traduzem sua experiência na interação. É a esse procedimento que será dedicado o tópico a seguir.

\subsubsection{A Pesquisa de narrativas: referencial metodológico}

"aquilo que é importante e relevante nas experiências é narrado"

O fenômeno em foco na presente pesquisa é o tornar-se mãe, mais especificamente os momentos iniciais do tornar-se mãe sob o contexto da prematuridade com necessidade de internação do filho na UCIN. Trata-se da experiência de mulheres tornando-se mães em um contexto adverso, quando abordagens qualitativas de pesquisa exploratórias da perspectiva e significações da mulher ao fenômeno maternidade se fazem necessárias.

A pesquisa qualitativa abarca o objetivo de compreender uma dada experiência humana a partir da perspectiva daquele que a vive. Para 
Wiklund, Lindholm e Lindström ${ }^{(39)}$, na escolha da abordagem metodológica, o pesquisador deve considerar a consistência propiciada pelo método para o acesso ao fenômeno em foco.

A pesquisa de narrativa é uma estratégia metodológica possível de ser utilizada na pesquisa qualitativa com o intuito de extrair, analisar e compreender histórias pessoais vividas ${ }^{(40-41)}$. Lieblich, Tuval-Mashiach; Zilber $^{(42)}$, ao descreverem focos de investigação que podem fazer uso da narrativa, afirmam ser uma das aplicações as investigações que focam períodos específicos ou momentos de transição do ciclo vital, o que vem de encontro ao objetivo do presente estudo.

As investigações narrativas são estudos nos quais as epifanias, rituais, rotinas, metáforas e experiências cotidianas são captadas, desveladas e exploradas ${ }^{(41)}$. Barton ${ }^{(43)}$ observa que a exploração pode ser conduzida com a co-participação dos envolvidos a fim de existir a coconstrução da história, em um processo circular de escutar, refletir e interpretar as histórias. Assim, a pesquisa de narrativa pauta-se no princípio de que o narrador seleciona, para a reconstrução da história, os componentes significativos, estruturando-os com o objetivo de alcançar a melhor retratação e tradução de sua experiência. Para tanto, o pesquisador precisa, para conseguir aproximar-se o máximo da perspectiva do pesquisado, ter uma escuta, um processo reflexivo e interpretativo muito desenvolvido e sensível (44). Os mesmos autores adicionam que o pesquisador deve se centrar nos significados retratados, os quais são desvelados através da forma dada à narrativa, da forma como ela é organizada e articulada. Três são os elementos chaves na estrutura de uma narrativa: o aspecto temporal, com o desdobramento dos eventos e ações; o aspecto do contexto, que abarca o enredo sobre o qual se desvela a justaposição dos eventos e ações explicitando significados, causas e conseqüências dos fatos; e aspectos tradutores das preocupações, sofrimentos e aborrecimentos ${ }^{(45)}$. 
Segundo Bakhtin (1981) apud Lieblich; Tuval-Mashiahch e Tamar ${ }^{(42)}$ trabalhar com narrativas requer uma escuta dialógica de pelo menos três vozes: a voz do narrador, a voz do referencial teórico que contém os conceitos a partir do qual a análise será estruturada por meio do processo de interpretação e, dada a monitoração reflexiva da ação de ler e interpretar, a qual é dependente da qualidade do pesquisador de concluir a partir dos dados, a voz do pesquisador. Este trabalho exige um processo interativo contínuo no pesquisador por meio do refletir, ler, ouvir e retomar idéias a partir da história narrada, ação esta mediada pela mente. O método exige igualmente do pesquisador auto-disciplina e a consciência de cada passo decidido ao longo do desenvolvimento do processo analítico.

Dentre as diversas possibilidades de ler, interpretar e analisar as narrativas, duas dimensões independentes ganham destaque $e$ determinam as quatro formas usuais de análise: quanto à unidade de análise, temos um posicionamento mais holístico que leva em conta o todo da história ou o posicionamento a partir de categorias cuja ênfase será em unidades menores e previamente selecionadas da história; quanto ao que é valorizado na análise, há a classificação em conteúdo ou forma. Na análise que considera a forma, a estrutura é o foco de atenção do pesquisador, enquanto que na de conteúdo, as temáticas são o foco principal. A interseç̧ão das dimensões traduz as possibilidades de leitura e tratamento das narrativas, ou seja, holística com ênfase na forma, holística com ênfase no conteúdo, de categorias com ênfase na forma, de categorias com ênfase no conteúdo(42).

O presente estudo optou pela perspectiva holística com ênfase no conteúdo. Os procedimentos metodológicos seguiram as recomendações de Lieblich; Tuval-Mashiach e Zilber ${ }^{(42)}$ e consistem em: 
- Leitura reiterativa de forma empática, do material coletado na tentativa de se estabelecer um núcleo central, um foco da história como um todo;

- Apontamento das impressões globais iniciais;

- Especificação dos termos ou focos de conteúdos a serem seguidos na reconstrução da história, por fim,

- Retomada da leitura reflexiva da história destacando trechos da narrativa que retratam os temas especificados, momento em que novos temas podem ser estabelecidos à medida em que o processo analítico se desenvolve.

\subsection{FATORES CONSTITUTIVOS DA PESQUISA}

\subsubsection{Local da Pesquisa}

Em função do fenômeno em foco ser a maternidade, os momentos iniciais do tornar-se mãe de filho prematuro com necessidade de UCIN, o local inicial de escolha para a realização do estudo foi UCIN. Optou-se por instituições públicas, detentoras da titulação "Hospital Amigo da Criança" na cidade de São Paulo por entender que, frente a esta titulação, há espaço e garantia da permanência da mãe junto de seu filho na UCIN, fato este nem sempre oportunizado, apesar da lei federal 8069, em seu artigo 12, garantir este direito à criança.

Foram enviadas solicitações a todas as instituições portadoras da titulação na cidade de São Paulo, das quais apenas duas responderam 
positivamente ao pedido. Os locais que concederam autorização para a realização da pesquisa são instituições públicas de assistência à saúde, uma na qual se desenvolve atendimento voltado especificamente à mulher e ao recém-nascido (instituição 1) e a outra inserida em um hospital geral de médio porte (instituição 2). Uma está localizada na zona leste e a outra na zona oeste da cidade de São Paulo e atendem população de baixo poder aquisitivo.

Ambas as UCINs têm as mesmas características e são aqui descritas conjuntamente. São planejadas para acomodar 20 leitos intensivos neonatais e flexibilizam o espaço para acomodar mais leitos sempre que necessário for. O espaço oficial do leito intensivo neonatal possui sempre a incubadora, uma poltrona reclinável, um painel com saída de gases e prateleiras ou suportes para a acomodação de equipamentos que venham a ser utilizados com a criança.

Um familiar pode permanecer junto ao neonato de forma integral durante o período diurno (das 07 h00 às 19h00), recebendo as seguintes refeições: café da manhã, almoço, lanche da tarde e jantar no refeitório do próprio hospital, com horários pré-determinados e que devem ser rigorosamente respeitados. A troca de acompanhante é livre e as visitas ocorrem em horários estabelecidos.

Ambas as instituições tem Banco de Leite Humano, para o qual as mães dos bebês da UCIN dirigem-se para extração do leite com a finalidade de ofertá-lo ao próprio filho, estocá-lo ou doá-lo. A ida a esse espaço é sempre estimulada pelos profissionais, observando-se horários rígidos e pré-definidos para seu uso.

Os usuários residem em bolsões de pobreza na cidade de São Paulo ou em cidades circundantes como Caieiras, Francisco Morato, dentre outras. A procura pelos hospitais pauta-se no conhecimento de que são locais de referência para o atendimento de gestação de alto risco. 
A equipe de assistência é composta pelos seguintes profissionais: médicos neonatologistas, enfermeiros, auxiliar e técnicos de enfermagem, psicólogo, assistente social e fisioterapeutas. Além deles, atuam na assistência alunos da residência médica em Neonatologia e da especialização em Enfermagem Neonatal, bem como as voluntárias.

Na escala oficial de colaboradores, há uma média de duas a três enfermeiras por turno designadas ao setor, vivenciando-se no dia a dia a permanência de uma ou duas enfermeiras por plantão em função das folgas. Elas assumem atividades vinculadas à sistematização da assistência de enfermagem (em ambos os locais restrita às fases investigativa, de planejamento - esse reduzido ao estabelecimento de prescrições de enfermagem - e de avaliação), colocação de horários na prescrição médica, encaminhamento das solicitações de exames diagnósticos e realização de procedimentos mais complexos como passagem de cateter central de inserção periférica, auxílio e atendimento às paradas respiratórias e cardiorrespiratórias, auxilio na retirada de tubos endotraqueais.

\subsubsection{Os sujeitos da pesquisa: um olhar sobre a representação identitária}

Fizeram parte do estudo 12 (doze) mulheres, das quais 10 (dez) estavam com seus prematuros hospitalizados nas UCIN das instituições mencionadas acima e 02 (duas) eram mães de crianças que foram prematuras e que estiveram hospitalizados em UCIN. Essas últimas ficaram sabendo do estudo e quiseram espontaneamente fornecer suas narrativas. 
Mãe 1

20 anos de idade, possuía ensino de nível médio, em relação consensual com um senhor de 33 anos, cuja profissão é ajudante geral. Ele é o pai da filha que acompanha na UCIN. Ela já engravidou outras quatro vezes, das quais pariu três. Em todas as vezes foram bebês prematuros, um menino e duas meninas. A primeira e o segundo filho faleceram respectivamente aos três anos por leucemia e aos quinze dias de vida por hemorragia pulmonar. A filha que acompanha na UCIN é prematura de 34 semanas, nasceu com $1690 \mathrm{~g}$ e, no dia da entrevista, tinha 15 dias de vida. Mãe e filha estavam vivenciando a primeira fase do Método Mãe Canguru, e os dispositivos utilizados pela crianças eram: incubadora, dispositivo venoso por onde recebia terapêutica voltada ao sistema respiratório, e sonda orogástrica fechada através da qual recebia nutrição enteral em concomitância ao seio materno. Ela encontrava-se desempregada, mas anteriormente exercia a função de caixa de barzinho. O marido e ela moram na região do Campo Limpo, em uma casa de três cômodos.

\section{Mãe 2}

34 anos, cursou até a $2^{a}$. Série do segundo grau, em relação consensual com o senhor V., de 33 anos de idade, dono de um barzinho, pai da filha que acompanha na UCIN. Essa criança é seu quarto filho. Os outros três filhos são de uma relação anterior, não foram criados por ela, moram com o pai e a mesma quase não os vê. A filha que se encontra na UCIN está com três meses, nasceu prematura com 32 semanas de idade gestacional e teve, ao longo de sua hospitalização, muitas complicações respiratórias em função da entubação prolongada. No dia da entrevista, a criança estava instável, fazia uso da incubadora, de dispositivos venosos para com terapêutica vasoativa, antibioticoterapia, soroterapia e nutrição parenteral. O casal mora no fundo do bar, localizado na região da Mooca. 
Seu atual companheiro, V., também já fora casado e, dessa relação tem uma filha de 11 anos que vive com a mãe.

Mãe 3

28 anos, cursou até a $4^{a}$. série do $1^{\circ}$. grau, em relação consensual com R., 29 anos há 7 meses. A filha nasceu prematura de 28 semanas e, no dia da entrevista, tinha 1 mês e 3 dias de vida. A filha encontrava-se na incubadora, com fototerapia e antibioticoterapia endovenosa. Recebia sua alimentação por copinho e seio materno. Desde o nascimento da filha ela mora com R. na casa dos pais dele, juntamente com uma cunhada. R. já teve duas relações anteriores, sendo pai de outros quatro filhos, uma da primeira relação e os outros três da última relação, sendo que um dos filhos dessa última relação também nascera prematuro de 30 semanas. Moram na região do Campo Limpo.

Mãe 4

42 anos de idade, $2^{\circ}$. grau completo, auxiliar de cobrança, solteira, mãe de J., prematura de 32 semanas. No dia da entrevista, J. tinha 27 dias de vida, estava na incubadora, com sonda orogástrica para alimentação, já sendo introduzida, em conjunto com sua mãe, à primeira fase do Método Mãe Canguru. Em função da mãe permanecer muito junto da filha, a alimentação era predominantemente feita por seio materno e copinho no período da noite, com pouco uso da sonda. A mãe possui outros dois filhos, cada um de uma relação. O primeiro filho tem 16 anos, a outra filha tem 4 anos e J. é filha de A. de 26 anos de idade. Ela e os filhos moram na região de Caieras. 
Mãe 5

28 anos, possuí magistério, é professora substituta do ensino público, casada com D. há 5 anos,motorista de ônibus, pai de seus quatro filhos. As idades dos seus filhos são: 4anos, 2 anos e meio, onze meses e L., de 20 dias de vida. L. nasceu prematuro com 32 semanas de idade gestacional. O casal mora com os quatro filhos na região da Penha. No dia da entrevista, o filho encontrava-se na incubadora, vivenciando com a mãe a primeira fase do Método Mãe Canguru e aguardando apenas ganho de peso para ser enviado para casa ou para a enfermaria Mãe Canguru.

Mãe 6

33 anos, tem o $2^{\circ}$. grau incompleto, trabalha como recepcionista, sua filha prematura é fruto de uma relação consensual de aproximadamente 1 ano com R., cuja profissão é cobrador. A filha prematura nasceu com idade gestacional de 27 semanas e no dia da entrevista, a mesma tinha dez dias de vida. Encontrava-se entubada, com dispositivos venosos para antibioticoterapia, nutrição parenteral, soroterapia, terapêutica vasoativa e corticoterapia. Estava de jejum com sonda orogástrica aberta. As outras duas filhas são de seu primeiro casamento e tem 11 e 8 anos. Vivem na residência ela e as filhas na região de Francisco Morato. O sustento da família é exclusivamente garantido por ela.

Mãe 7

28 anos, tem o $2^{\circ}$. grau completo, casada há 4 anos com R. de 33 anos. Ele é segurança e, assim como ela estava desempregado. Mãe de 
gemelares que nasceram prematuros com 26 semanas de idade gestacional. Um dos gêmeos faleceu com 3 dias de vida e o outro, no dia da entrevista tinha 25 dias de vida. Ele encontrava-se na incubadora, sob CPAP, com dispositivos venosos para corticoterapia, antibioticoterapia e soroterapia. Estava sendo alimentado exclusivamente de forma enteral através de sonda orogástrica, apresentando muito resíduo. Reside com o marido na região de Francisco Morato.

Mãe 8

18 anos, estudante do 20. grau, solteira, recepcionista de uma academia. É a mãe de G., nascida prematura de 29 semanas, fruto de uma relação consensual com R., de 24 anos, proprietário de uma academia de ginástica. G. encontrava-se em incubadora, entubada, em jejum com sonda orogástrica fechada e dispositivos venosos para corticoterapia, antibioticoterapia, soroterapia e nutrição parenteral. Ela mora com a sua mãe e a avó na região do Belém. No dia da entrevista G. tinha 1 mês e sete dias de vida.

Mãe 9

42 anos, superior completo, enfermeira, casada com P.. Sua filha nasceu com 29 semanas de idade gestacional e a entrevista foi realizada 3 anos após o nascimento da mesma. Reside com seu marido e a filha na região do Campo Limpo.

Mãe 10

45 anos, superior completo, docente universitária, casada com J., publicitário. Seu filho nasceu prematuro de 28 semanas de idade 
gestacional e a entrevista foi realizada 4 anos após o nascimento do mesmo. Tem outra filha de 5 anos de idade, ambos filhos de seu casamento com J.. Residem na região do Morumbi.

Mãe 11

24 anos, 10. grau incompleto, faxineira, em relação consensual com C. há 3 anos. Ele encontrava-se desempregado. É mãe de M., prematuro com 38 dias de vida no dia da entrevista. Nasceu com 30 semanas de idade gestacional e encontrava-se na incubadora, já realizando com sua mãe a primeira etapa do Método Mãe Canguru, aguardando vaga na enfermaria Mãe Canguru. Moram em casa de dois cômodos na região do Parque do Lago.

Mãe 12

26 anos, tem o $2^{\circ}$. grau completo, do lar, casada há 3 anos com L.. Mãe de três filhas, as gêmeas que nasceram prematuras com 31 semanas de idade gestacional e outra menina de 2 anos. As gêmeas encontravamse no dia da entrevista com 10 dias de vida, ainda estavam entubadas, na incubadora, de jejum com sonda orogástrica aberta, sob fototerapia, com dispositivos venosos para antibioticoterapia, corticoterapia, soroterapia e nutrição parenteral. O casal reside na região do Belém.

\subsubsection{Aspectos éticos}

Com a obtenção da autorização do Comitê de Ética da Escola de Enfermagem da Universidade de São Paulo (anexo 1) para o 
desenvolvimento da pesquisa, foi solicitada autorização junto às instituições hospitalares da cidade de São Paulo detentoras do título Hospital Amigo da Criança que já haviam apontado abertura para o o trabalho ser efetivado. Após a autorização formal das instituições, foi iniciado o trabalho de campo. Dirigia-me à UCIN e, com o auxílio dos profissionais da saúde que ali estavam, procurava obter informações a fim de verificar a contemplação dos critérios de inclusão estabelecidos:

- Mães de prematuros internados na UCIN, devendo a internação estar pautada apenas na prematuridade e no impacto da prematuridade sobre a maturidade dos órgãos da criança, e não ter esta criança malformação associada;

- Opção livre e esclarecida da mãe para participar da pesquisa, oficializado por meio do Termo de Consentimento Livre e Esclarecido (apêndice A).

Cabe explicitar que, frente à identificação de que a mãe atendia ao critério de inclusão acima descrito, a pesquisadora dirigia-se a ela expondo a finalidade e estratégias da pesquisa, explicitando a necessidade de gravação da mesma em fita K-7. Frente à sinalização de aceite dela em participar, procurava estabelecer dia e horário para a entrevista. Antes de proceder a entrevista, a pesquisadora retomava a finalidade e as estratégias, lia o Termo de Consentimento Livre Esclarecido (TCLE) junto com a mãe, ficando disponível para responder a quaisquer dúvidas que viesse a expressar. Na confirmação verbal do aceite de participação, procedia-se o preenchimento do TCLE em duas vias, ficando uma com a pesquisadora e outra com a mãe.

Como já observado na apresentação dos sujeitos participantes, houve a coleta de dados com outras duas mães que, conhecedoras do estudo, quiseram espontaneamente fornecer suas narrativas. Frente ao aceite de participar da pesquisa, todos os procedimentos éticos foram seguidos. No dia agendado, o TCLE foi lido em conjunto com elas, para então ser 
assinado e proceder-se à entrevista. Essa foi igualmente gravada em fita K-7 para ser posteriormente transcrita e analisada.

As duas mães que espontaneamente quiseram fornecer suas narrativas para o presente estudo adotou-se os seguintes procedimento éticos: frente à manifestação própria de contarem suas histórias, retomou-se o objetivo do estudo explicando os procedimentos de coleta e tratamento dos dados certificando-se novamente o interesse em conceder de forma espontânea suas narrativas. Frente à confirmação, combinou-se data e local para a coleta dos dados. No dia marcado o TCLE fora lido em conjunto com elas para então ser assinado e proceder-se a entrevista. Essa foi igualmente gravada em fita K-7 para ser posteriormente transcrita e analisada.

\subsubsection{Coleta dos dados: a entrevista em seu meio estruturante}

Em ambas as instituições, a pesquisadora desenvolveu, em primeira instância, observação do contexto da UCIN a fim de aproximar-se da realidade ali vivida, sensibilizar-se para o tema da pesquisa e atentar-se para peculiaridades estruturais e relacionais do contexto.

Algumas conversas informais com mães e famílias que se mostravam disponíveis para interação e/ou que as buscavam espontaneamente, foram estabelecidas e propiciaram reflexões e ponderações acerca de focos de preocupação e estratégias maternas adotadas ao longo da estada na UCIN.

Por meio de ambas as estratégias, a pesquisadora estabeleceu contato inicial com a experiência das mães e registrou as mesmas como "notas de observação". 
Minayo ${ }^{(46)}$ aponta a observação como promotora da aproximação do pesquisador do fenômeno em estudo. Já as "notas de observação" constituem-se em elementos para geração de hipóteses, com favorecimento de decisões acerca da coleta e interpretação dos dados.

A entrevista foi estratégia adotada para acessar as narrativas das mulheres sobre a experiência de tornarem-se mães sob o contexto da prematuridade e hospitalização do filho na UCIN. Nessa modalidade de coleta de dados, o pesquisador convida o sujeito a contar o que aconteceu em uma dada situação e permite a fala ininterrupta até o completo desenrolar da história. Perguntas abertas e favorecedoras da narração são as indicadas para este fim. No caso do presente estudo, a pergunta utilizada foi "Conte para mim como está sendo tornar-se mãe na UCIN". Outras observações e questionamentos foram realizados apenas na identificação da necessidade de ampliar descrições ou elucidar articulações dos aspectos narrados, conforme recomenda Greenhlgh, Russel e Swinglehurst ${ }^{(45)}$. A entrevista não estruturada permite a expressão de sentimentos, crenças e significados vinculados ao fenômeno em exploração.

Assim, ao longo das narrativas maternas, a pesquisadora desenvolveu escuta atenta, com respeito e curiosidade sobre o que estava sendo dito, buscando compreender o foco dado ao fenômeno em pauta, a fim de explorar palavras e expressões que favorecessem a clarificação do que estava sendo narrado, bem como capturar a organização/forma dada às narrativas. Aspectos tradutores de sentimentos, processos de comunicação e interação receberam uma ênfase na clarificação.

A abordagem anterior à entrevista foi a realização do genograma e ecomapa familiar. O genograma é um diagrama representativo da estrutura familiar interna, sendo usual incluir três gerações nesta representação(26). A estrutura interna abrange seis subcategorias que podem ou não ser exploradas, de acordo com a percepção da real 
importância do dado. São elas: composição familiar, gênero, orientação sexual, ordem de nascimento, subsistemas e limites. O ecomapa é "uma representação das relações da família com suprasistemas (pessoas significativas, instituições do contexto da família)" (26). Nele, busca-se caracterizar as relações em termos de intensidade e presença de conflitos.

Os genogramas e ecomapas das famílias das mulheres participantes do estudo favoreceram a empatia e a condução da entrevista.

\subsubsection{Análise dos dados: a análise das narrativas com abordagem holística temática}

Todas as entrevistas foram transcritas em sua íntegra e sofreram os processos analíticos preconizados pelo método da pesquisa de narrativas com abordagem holística temática, conforme exposto no item 1.2.2.

Clandinin e Connelly ${ }^{(41)}$ destacam que, na pesquisa narrativa, há a contextualização das histórias na história de vida e cultura do narrador, bem como no momento histórico vigente.

Para estes mesmos autores, no recontar da narrativa com a integração das diversas narrativas obtidas, deve-se considerar a organização dos dados de maneira cronológica e pautada em elementos da narrativa, como tempo, espaço, enredo e contexto. Greenhlgh, Russel e Swinglehurst ${ }^{(45)}$ corroboram com os autores acima na estruturação da narrativa segundo a cronologia, com a atenção de articular, dentro da perspectiva tempo e dos marcos do processo vivido, a narrativa integradora das narrativas obtidas.

Todo o processo estrutura-se na atitude reflexiva do pesquisador diante da história narrada. Exige uma reflexão analítica com proposição de 
categorias/unidades temáticas e constante retomada da história para afirmar a explanação aferida, bem como trazer novas sensibilizações interpretativas.

Creswell ${ }^{(47)}$ descreve quatro abordagens para as práticas analíticas utilizadas na pesquisa de narrativa: a cronológica, a que enfoca o enredo, o modelo tridimensional e a temática. Já Lieblich et al apud Bleakley ${ }^{(40)}$ sugere uma estrutura analítica pautada em duas dimensões: a holística versus a de categorização; e, a de conteúdo versus a da forma, que combinadas entre si, resultam em quatro abordagens possíveis. A abordagem holística considera a história como um todo, contextualizandoa na cultura e história envolvida; já a categorização tende a dissecar episódios particulares. Por sua vez, conteúdo volta-se para o que ocorre na narrativa e forma traduz o como as coisas acontecem.

As pesquisas narrativas têm como exigência metodológica a análise da história em seus blocos de texto. Muller (1999) apud Greenhlgh, Russel e Swinglehurst ${ }^{(45)}$ apresentam os seguintes passos analíticos da narrativa: leitura do texto narrado com marcação preliminar de códigos; fase interpretativa, na qual, por meio de sucessivas leituras e reflexões, vão se estabelecendo as conexões dos aspectos narrados; verificação, momento no qual explora-se o texto para alternativas de explanações e certificação ou não dos dados; representação, o que significa escrever o texto a partir do que se descobriu por meio da análise; e, ilustração, ou seja, seleção de trechos ilustrativos.

Frank (s/d) aponta ser importante identificar em que momento a narrativa se inicia e termina, como é marcado o início e fim da história narrada e como a construção foi elaborada para responder a pergunta proposta. Destaca ainda a importância de atentar-se à forma como narra sua história a fim de sensibilizar o pesquisador para aspectos que a constituem. 
Assim, o primeiro passo do processo analítico desenvolvido na presente pesquisa foi transcrever as narrativas em sua íntegra, realizar leituras atentas, separar "blocos de textos" articulados ao fenômeno em estudo, com posterior nomeação do aspecto tratado nos "blocos de textos" selecionados para análise. A repetida revisão das histórias permitiu ao pesquisador aproximar-se da perspectiva do narrador. Buscou-se continuamente dar interpretação que abarcasse os temas integrantes do fenômeno em foco, bem como o contexto e as nuances específicas de cada mulher, tentando integrá-las no recontar da história tradutora do fenômeno aqui tratado: momentos iniciais do tornar-se mãe no contexto da prematuridade com necessidade de UCIN.

Para Clandinin e Connelly ${ }^{(41)}$ no processo analítico há a necessidade de considerar a narrativa como espaço no qual interações, continuidade e situação estão contidos e articulados. Frente a estas colocações, o pesquisador, por meio do processo analítico, deve conseguir recuperar a conexão das representações, o que traduz a própria história, valorizando a interação entre as experiências pessoais e sociais. Plumer (2001) apud Barton $^{(43)}$ diz:

"... Estas histórias ... conectam o mundo interno com o mundo externo, conversam com o subjetivo e o objetivo, e estabelecem as marcas da identidade... ${ }^{(43, \text { p.395)" }}$

Outros focos de atenção no processo interpretativo são a continuidade da narrativa, articulando passado, presente e futuro e, a contextualização da situação narrada.

Cada história contribuiu para o conhecimento do todo do fenômeno sem extrair a voz de cada narrador. 
Por fim, embora se saiba que, dentre as limitações deste método, há um consenso em se apontar a dependência do narrador e de sua perspectiva, visto ser ele que conta, segundo significação e organização estabelecidas em sua mente, será que o recontar, seja qual for - o da leitura de dados transcritos, o da notícia transmitida etc - não implica sempre em uma representação da história que não é o que, de fato, the atribui sentido? Sempre que há o recontar, quaisquer que sejam os meios que o sustentam, não há jamais a mesma história, e isso é constitutivo da apreensão do mundo pelo homem ${ }^{(45,49)}$.

Considerando ainda que o presente estudo optou pela perspectiva holística com ênfase no conteúdo e que os procedimentos metodológicos, tal como apontados em 1.2.2, seguiram as recomendações de Lieblich, Tuval-Mashiah, Zilber ${ }^{(42)}$, na aplicação de tais procedimentos na manipulação dos dados, várias questões foram evidenciadas em cada etapa, propiciando melhor delimitação e entendimento dos resultados obtidos.

Assim, consistindo a primeira etapa na leitura de forma empática com vistas ao estabelecimento de um núcleo central, um foco da história como um todo, neste estudo, chama a atenção, em primeira leitura, o desgaste da mulher e a necessidade de adaptação ao processo.

A segunda etapa preconizada pelos autores consiste em escrever as impressões globais iniciais, quando exceções às impressões gerais, contradições, descrições pouco densas, aspectos que representam incômodo ao narrador e ao pesquisador pode $\mathrm{m}$ ser explicitamente descritas no material de análise e interpretação.

A terceira etapa, contemplando a tomada de decisão em relação aos temas em focos de conteúdos a serem seguidos para construir a história, bem como o destaque de temas da narrativa que retratam estes temas, momento em que novos temas podem ser estabelecidos. No presente 
estudo, blocos de narrativa foram destacados e os temas ali presentes extraídos.

Após a identificação dos temas das diversas narrativas que compuseram o presente estudo, agruparam-se os relacionados a cada tema, para então prosseguir o processo de análise: reconstruir a narrativa.

Os temas do presente estudo foram agrupados em dois momentos temporais: antecedentes ao nascimento da criança e sua ida à UCIN e relativos aos momentos vividos com o filho na UCIN.

Com relação aos temas vinculados aos momentos que antecederam o nascimento do filho e sua ida à UCIN tivemos: parto prematuro; sobrevivência do filho; vínculo com o filho; preocupações.

E como temas relativos aos momentos vividos com o filho na UCIN, tivemos: estar junto; adversidades; limites; aprendizagens; desgaste; amamentação; espiritualidade; elementos facilitadores; demandas da família; alta.

O passo seguinte foi ler o material e verificar como cada tema foi desenvolvido, que conclusões dele decorriam.

Atentar-se para o desenvolvimento de cada tema, para o contexto relacionado a ele, as articulações ao todo do processo estudado, são cuidados exigidos pelo método. Concomitantemente, houve revisão das designações aferidas a cada tema e a rticulação entre eles o que permitiu descrever a narrativa tradutora do fenômeno em estudo. 
Parte II

Apresentação dos resultados 
Os resultados estão organizados em dois momentos experienciais, um que traduz aspectos narrados em relação ao período anterior ao nascimento/necessidade de internação do filho na UCIN e outro que se relaciona ao período na UCIN.

As unidades experienciais permitiram caracterizar as dimensões tradutoras do processo de tornar-se mãe sob o contexto da prematuridade com necessidade de UCIN, limitando-se a esse cenário. O curso da maternidade altera-se com a prematuridade, mas a proteção, elemento maternal, está presente e mantido, com investimentos progressivos da mulher para ampliar a manifestação de ações tradutoras do mesmo ao longo da dimensão temporal de sua estada na UCIN. O tempo necessário para encontrar o espaço, bem como as condições e os recursos necessários para expressar toda sua maternagem, são peculiares a cada mãe em sua cronologia. Trazem momentos de grande sofrimento, incertezas, impotências e luta para a mulher, o que determina este início como difícil.

A presente pesquisa enfocou suas explorações neste âmbito, ou seja, no início da trajetória do processo de tornar-se mãe na UCIN, entendido como aquele no qual a mulher ainda não se sente integrada ao contexto do filho e, também, não consegue ter a clareza do como conceitua e expressa a maternagem. Os resultados foram agrupados sob três temas tradutores e integradores dos significados presentes nesta fase.

Proteger o filho caracteriza a ação materna predominante e desvelase por meio do sentir-se responsável pelo filho e estar junto do filho. Lutar para manifestar a proteção é a estrutura central da narrativa desvelada após análise dos dados, sendo esta dependente do encontro e sensação de segurança para expressar seu jeito de ser mãe. O maternar tem íntima articulação com o sentir-se adaptada/ não adaptada. Esse sentimento é 
conseqüência da segurança que a mulher adquiriu frente ao desenvolvimento de seu papel, o que por sua vez, é dependente dos aprendizados adquiridos ao longo de sua estada na UCIN. Os aprendizados contribuem para que a mulher/mãe encontre a paciência para esperar, para lidar com os limites, para valorizar as possibilidades concebidas como maternais, a administrar a situação de forma mais organizada e consciente. Com isto, tramita paulatinamente para uma clareza na concepção do papel materno e, à medida que consegue significá-lo, desenvolver ações pautadas nele, com segurança. Portanto, a mulher/mãe progride de uma condição onde é, na maior parte do tempo, executora de ações esperadas por outrem (profissionais/ família) para uma condição onde tem clareza das ações de maternagem que deseja desempenhar, bem como quais e onde se encontram os entraves para o exercício das mesmas.

Com isto, adquire o conhecimento das possibilidades para exercer a maternagem, bem como, aprende como argumentar para a concretização da mesma. Negociar sua presença é um aprendizado desenvolvido ao longo do tempo, sendo o meio pelo qual a mulher concretiza sua identidade materna na UCIN. Na medida em que ela vai convivendo com o contexto da UCIN, ela passa a conhecê-lo e, com isto, identifica a maneira como ampliará seu espaço para fazer-se presente na concepção de mãe que prospecta. Como resultado, as ações de proteção, apesar de exercidas desde o início da trajetória da experiência de tornar-se mãe na UCIN, ampliam-se para uma manifestação progressivamente mais consonante com a identidade materna almejada pela mulher, em contrapartida à esperada pelos profissionais, membros da família e outras pessoas com as quais ela interage.

Ao longo da vivência dos processos descritos acima, a mulher/mãe ora sente-se adaptada, ora não se sente adaptada. Esta sensação de adaptação ou não está diretamente ligada à clareza que vai adquirindo em relação ao contexto da UCIN e à identidade materna almejada por ela, o 
que repercute em um manejo melhor do contexto interacional em que se encontra. De maneira geral, à medida que o tempo passa, a mulher/mãe tende a ter mais elementos para conceber o papel materno e a UCIN, contextos esses seu e do seu filho, e, com isto, aprende a interagir de forma a criar a menor quantidade de conflitos explícitos possíveis, a fim de conseguir ser e estar na UCIN com certa consonância para com suas expectativas e as da UCIN, principalmente na pessoa dos profissionais. Assim, o sentir-se adaptada agrega uma situação na qual esta mulher/mãe conseguiu manifestar-se de forma a ter equilíbrio entre o seu eu e o contexto com o qual interage, sabendo como administrá-los.

Em contrapartida, sente-se não adaptada toda vez que há conflito entre ela e a UCIN, ora agindo mais a atender as expectativas dos outros, ora por não atender em quase nada tais expectativas em função do desconhecimento do que é esperado dela, dos seus limites na unidade, de particularidades dos próprios profissionais, de saberes a respeito de seu bebê. Saber manifestar-se no ou próximo do ponto de equilíbrio entre as expectativas suas e de outrem é aprendido ao longo do tempo e traduz a sensação da mulher de adaptação. Sensação essa promotora da experiência de tornar-se mãe. Adequar-se é habilidade apreendida ao longo do tempo e está dependente da capacidade de negociação adquirida e dos aprendizados que vai acumulando ao longo da jornada de tornar-se mãe na UCIN.

Cabe destacar a existência de um crescimento da mulher como pessoa ao longo da experiência de tornar-se mãe na UCIN, principalmente em função das limitações e pressões externas com as quais convive. Essa sensação de estar sendo constantemente exigida gera desconforto na mulher e, é um dos aspectos mobilizadores do enfrentamento da situação.

A fim de descrever com maior propriedade o fenômeno de tornar-se mãe na UCIN, os resultados estão organizados a partir dos seguintes temas, decorrentes do acima exposto e dos momentos vividos na UCIN: 
1. PROTeger O FILHO, composto pelos subtemas estar junto do filho e agir em prol do filho;

2. APRENDER, composto pelos subtemas administrar as pressões; suportar a espera; conviver com as limitações, superar o cansaço; resgatar energias; buscar a espiritualidade;

\section{SENTIR-SE MÃE.}

Lutar para a ampliação e autenticidade da maternagem traduz o resultado da integração dos processos descritos nas unidades temáticas, e coloca a mulher em uma condição onde a administração das pressões internas e externas é mais eficiente. Ela passa a enfrentar com maior tranqüilidade o restante da experiência por ter alcançado a segurança no seu jeito de maternar.

A ida do filho à UCIN não foi, contudo, aspecto previamente ponderado por nenhuma das mulheres do presente estudo. Todas as entrevistadas, ao narrarem suas histórias de tornarem-se mães, trazem descrições de momentos da gestação quando viviam a experiência de tornar-se mãe sob o papel de mãe que haviam prospectado. Assim, com o nascimento prematuro, o projeto é alterado, porém, apesar dessa alteração, observam-se aspectos ali vividos que influenciam os momentos atuais, retroalimentando-os positivamente no sentido de identificarem que já exerciam a maternagem.

Daí incluir-se o tema SENTIR-SE RESPONSÁVEL PELO FILHO que traduz os aspectos narrados em relação ao período anterior à estada na UCIN. Este integra as ações maternas e as significações que lhe são atreladas neste período por meio dos subtemas: acolhendo o filho, vivendo a incerteza da maternidade e tornando-se mãe.

Perceber que já tinham ações de proteção pelo filho é elemento que nutre a mulher em seu processo de tornar-se mãe na UCIN, sendo pela análise deste tema que evidenciamos os resultados a seguir. 


\subsection{TEMA: SENTIR-SE RESPONSÁVEL PELO FILHO}

Esta unidade temática integra os subtemas acolhendo o filho; vivendo a incerteza da maternidade e tornando-se mãe. Ela aponta para a existência preemente do cerne da identidade materna de sentir-se responsável por alguém e de querer protegê-lo. Tem influência nos momentos que são vividos na UCIN, no sentido de oferecer à mulher a certeza de ter agido em prol do filho, de ter tido ações concebidas por ela como maternais.

Nas narrativas descritoras deste momento da trajetória, há uma forte orientação para o futuro. A mulher vislumbra e acredita na possibilidade do domínio sobre os fatos, no conseguir alterar o que está sendo vivido e o que pode ver a sê-lo. A consumação da prematuridade conduziu a mulher ao questionamento da previsibilidade, da possibilidade de ter domínio do futuro. Resgatar estas vivências traz para a identidade materna a imprevisibilidade da possibilidade de garantir as coisas para outrem, no caso o filho. Percebem a necessidade de não se estruturarem tanto no prever, de a identidade materna naturalmente conter essa nuance.

Podemos dizer ser este aspecto será um dos aprendizados vividos pela mulher ao longo da experiência na UCIN.

Subtema: Acolhendo o filho

Frente à identificação de que está gestante, a mulher concebe-se como mãe e projeta expectativas para o seu desempenho neste papel. As 
mães do presente estudo destacaram o mediar a integração do filho no sistema familiar como uma de suas primeiras responsabilidades. Entende ser seu papel introduzir e ampliar o espaço da criança na família. Assim, utiliza-se dos conhecimentos detidos e estimula atitudes e diálogos relacionados ao filho no contexto em que interage. Por exemplo: estimula o marido passar a mão na barriga, instiga conversas sobre a criança, conversa com os outros filhos sobre o filho que está por vir, dentre outras ações. Assim, ao ser introduzida ao mundo do tornar-se mãe, a mulher significa-se como aquela que garante à criança um contexto propício, acolhedor, o que a faz ponderar o que será encontrado pela criança e o que deve ser modificado em função daquilo que ela concebe como adequado, ideal de ser provido. Ela já adota, a partir deste momento, a responsabilidade pelo contexto da criança e tem ações orientadas para a sua melhoria. Entende-se contexto como tudo aquilo que irá entrar em interação com a criança.

Assim, ela lança-se em um progressivo processo de propiciar um contexto acolhedor ao bebê. Ela deseja que o bebê sinta-se bem vindo. Para tanto, conversa com seu companheiro e/ou com seus familiares e amigos sobre anseios e expectativas em relação à criança, sobre a própria criança, sobre o que concebe como ideal para o seu desenvolvimento.

Destaca-se o fato da orientação de suas ações ser sempre direcionada ao futuro, buscando antever possíveis dificuldades, com intenção de planejar e sensibilizar alterações dentro do funcionamento e valores familiares para alcançar o contexto por ela concebido como ideal. É parte da expressão de seu eu ter preocupações sobre o amanhã da criança.

As preocupações são de âmbitos distintos, sendo as mais mencionadas neste estudo relativas ao contexto físico da casa e ao contexto interacional da criança, quando seus objetivos se centram, como dito anteriormente, em prover um ambiente acolhedor, um ambiente no 
qual a criança sinta-se reconhecida em sua individualidade, quista e bem vinda, e tenha suas necessidades atendidas.

A ação mais mencionada em relação ao contexto físico foi adequar o ambiente onde a criança dormirá, o que determinou ações como pintar a casa, tentar ou até mudar de casa, dentre outras.

A ação mais mencionada em relação ao contexto interacional foi intermediar a progressiva aproximação do companheiro e do restante da família da criança.

Os aspectos apontados acima se iniciaram, nas mulheres do presente estudo, assim que foram notificadas da gestação e mantiveramse ao longo do tempo da gestação.

desde que soube que estava grávida, eu conversei com elas, falei que elas eram bem-vindas, que eu as amava muito. Meu marido também conversava com elas. Eu falava assim, filhinhas o papai chegou, ele passava a mão na minha barriga, ele beijava minha barriga, tudo. Sabe carinho que a gente ia mostrando que já tinha por elas. (mãe 12)

quando soube que estava grávida, já fui preparando tudo... afinal teria um filho. Fiz de tudo para correr tudo bem. Já pensava nele em casa, em como seria o cantinho dele e ele entre nós. O quarto dele estava ficando lindo, mandei pintar a casa, estava já preparando tudo, mas ele não deixou a gente terminar... foi apressadinho, quis vir antes. Já está tudo bem, agora ele já não me dá mais muito susto. A gente tanto que queira que tudo corresse como estávamos planejando, mas... não deu. O pai dele sempre conversava com ele que eles iam aprontar junto. Acho que ele ouviu o pai. Eu falei para o meu marido pode conversar que ele ouve, e ouviu, viu. Sapeca este menino. Agora está aí, vamos continuar fazendo de tudo para 
ele. É nosso agora, já está aqui com a gente. A gente sempre amou ele, desde a barriga e agora ainda mais... (mãe 11)

\section{Subtema: Vivendo a incerteza da maternidade}

A possibilidade da interrupção inesperada da gravidez, seja meses ou minutos em que os fatos promotores estejam ocorrendo, acarreta um parto/nascimento avaliado como tumultuado, uma vez que os eventos vão se desenrolando de forma repentina, sem perspectiva de elaborá-los e acomodá-los em suas experiências de vida. A mulher sabe que o parir a eternizará no papel de mãe, e, com a interrupção prematura da gestação, neste primeiro momento, em mães de prematuro(s). Essa introdução à maternidade traz incertezas e preocupações: ocorrerá de fato o parto/nascimento; suportará a criança a vida extra-uterina; tem a criança maturidade para tanto?

Cabe ressaltar o fato de todo o investimento descrito anteriormente em relação ao procurar prever e agir para evitar entraves sofre um insucesso e, em função disso, a mulher precisa encontrar novamente a estrutura sobre a qual edificará sua ação de garantir à criança o contexto mais ideal possível para seu desenvolvimento e crescimento. Porém, o mundo da prematuridade não é plenamente conhecido por ela. Apenas alguns saberes estão disponíveis, sendo em sua maior parte, superficiais, com um leque enorme de possibilidades. Esta falta de previsão sobre a probabilidade de como o processo se desenrola coloca as mulheres em uma posição de insegurança e medo. Elas sabem que não podem antever aspectos para a criança e necessitam esperar pela concretização do nascimento para conseguir visualizar melhor a realidade na qual serão introduzidas. 
Algumas informações que detém as fazem encontrar âncoras para estruturar a espera da realidade a ser vivida. Por exemplo, conhecimentos sobre idade gestacional e maturidade orgânica; sexo da criança; dentre outros.

Eu sabia que ia nascer pequena, então a gente se preocupa com as condições, com a maturidade pulmonar, como é que ela viria, e, conforme foi se cristalizando de que não estava melhorando, que ao contrário estava diminuindo cada vez mais o líquido amniótico e, você via a iminência do parto você vai se assustando, fica muito preocupada o que será que vai acontecer, como será que vai ser o desenrolar desse nascimento, dessa situação de ficar na UTI, quanto tempo será que vai precisar ficar, qual vão ser as condições? Eu sabia que era uma menina, então de certa forma isso me tranqüilizava um pouco, pois eu sabia que normalmente as meninas respondem melhor à situação de prematuridade. Então, mas com a proximidade do parto, veio uma preocupação grande de como é que ela iria nascer, quais seriam as condições que ela estaria para enfrentar nesse mundo, não estando preparada completamente. Isso era uma preocupação bastante presente, principalmente na iminência do parto e no parto. (mãe 9)

Eu estava muito, muito inchada, eu já estava percebendo que não ia até o fim, que elas viriam antes. Assim que comecei a inchar já percebi que elas iam nascer antes. Do quarto para o quinto mês eu comecei a ter alteração na pressão, eu estava muito inchada, meus pés, eu nem conseguia calçar sapato de tão inchada. Eu estava enorme, enorme. Até quando eu vim aqui, eu pensei que eu ia ficar internada, não imaginava que ia ter elas, achava que ia ficar internada. Foi um susto.(mãe 12) 
Todas elas desejavam e agiram para evitar o parto prematuro, porém, ante os seus sinais, percebem que a chegada antecipada da criança é fato, e a ela está posto o contexto da prematuridade. Neste momento, ela está se tornando mãe de prematuro(s) e irá enfrentar os desdobramentos disso. Portanto, a interrupção da gravidez antes do tempo é o evento que pode conceber a mulher como mãe de prematuro, e impor a prematuridade como realidade a ser vivida.

A tentativa de evitar este fato fez-se presente nas histórias de algumas mulheres, quando medidas profiláticas ao trabalho de parto prematuro vinham sendo adotadas. Outras têm o parto prematuro como um evento súbito em suas vidas. Todas vivem, contudo, uma grande tensão e angústia pelo o que elas e o filho estão enfrentando e terão de enfrentar. Preocupações atreladas a esse fato tomam conta de seus pensamentos e reflexões ao longo de todo o trabalho de parto e parto. Mais especificamente, lutam para que seu desfecho seja marcado pela sobrevivência do filho e sabem da importância de que tudo seja feito rapidamente e da forma mais eficaz possível. Ou seja, os sinais do trabalho de parto prematuro, colocando-na no limite da concretude da prematuridade e da maternidade,faz com que ajam para garantir que a sobrevida do filho ocorra. Pensam sobre a idade gestacional e as concepções que possuem em relação à situação em que se encontram seus bebês, refletem sobre a maturidade da criança para a vida extrauterina e ponderam todos os conceitos vinculados à UCIN e prematuros detidos ao longo de sua história de vida. Todas as reflexões e pensamentos estruturam-se em cima de possibilidade de sobrevida, necessidade de estada do filho na UCIN e sua vontade de ter o filho consigo, junto a sua família.

Eu bem que percebi que havia algo errado, sentia-me diferente, mas não sabia o que ao certo. Tentei descobrir, falei para o médico do posto que eu estava me sentindo estranha, mas ele 
disse que não tinha nada. Ele não percebeu que minha pressão estava subindo. Vai ver que na hora que ele media não estava alta mesmo. Eu até ficava bastante deitada, tinham me dito para eu tentar descansar mais. Eu descansei, mas não adiantou, ele veio antes mesmo. Foi tudo um susto, mas agora já está tudo bem e eu já estou bem também. Fiquei muito preocupada no momento que cheguei aqui, queria apenas que salvassem meu pequeno. Foi um susto, um desespero, parecia que eles demoravam em fazer as coisas, eu fiquei muito nervosa, descontrolei. Fiquei com muito medo de perdê-lo, de que as coisas não dessem certo. Agora está tudo bem, eu já estou bem, já sei como as coisas funcionam aqui. Agora é só esperar para levá-lo embora. Não vejo a hora. (mãe 11)

Com a identificação de sinais anormais, como dores, sangramentos, as mulheres acionam pessoas que possam a conduzir rapidamente ao hospital para que sejam tomadas medidas adequadas em relação ao evento. Algumas não vêem estes sinais como de trabalho de parto e acreditam estar indo para receberem prescrição de ações a serem efetuadas a fim de manterem a gestação. Outras já são conduzidas ao local em pleno trabalho de parto/parto ou possuem a nitidez de que os sinais retratam um parto prematuro iminente. Independentemente destas peculiaridades, são momentos tidos como decisivos, vividos com grande intensidade em termos de preocupação, medo e tensão, pois sabem que há algo atrelado ao bem-estar do filho ocorrendo. Sentem-se com pouco domínio sobre os eventos, identificam precisarem de outras pessoas que Ihes asseguram possibilidades de desdobramentos os mais positivos possíveis. Elas temem a não sobrevida do filho e as possíveis seqüelas que ele possa vir a ter e passam todo o processo de trabalho de parto e parto imersas nessa preocupação, imersas na ansiedade do desfecho desse momento. Identificam-no como decisivo em suas vidas. 
De repente eu senti dores muito fortes. Falei para o meu marido e ele ficou desesperado. O vizinho é que acabou nos trazendo para cá, meu marido nem conseguia pensar direito. No carro, aquela correria, parecia que todo o trânsito queria encontrar com a gente, minhas dores só pioravam, eu fiquei muito nervosa, pensei que não ia conseguir chegar a tempo, só chorava, pensei que não ia conseguir ganhar o neném. Foi horrivel, parecia que nunca íamos chegar, e olha que o_ é perto da minha casa. Um desespero total. Mas, foi graças a correria que chegamos a tempo, fui para a sala de cirurgia rapidinho, nem me examinaram, já fui direto, acho que minha cara de dor e meu desespero eram muito grandes. Quando o médico falou olha, fique calma seu bebê já está sendo atendido, daqui a pouco vamos saber mais dele é que eu fui me tranqüilizando, ele nasceu, está vivo, será que está bem? Fiquei a todo momento pensando nisto, parece que nunca entrava alguém para me falar dele. Que desespero. Até que falaram que ele já estava na UTI e que assim que passasse a anestesia eu podia ir vê-lo. Não via a hora de ir lá. Ficava só pensando o pior e o melhor, é estranho, você quer acreditar, mas ao mesmo tempo pensa coisas ruins. (mãe 11)

Assim, todo o trabalho de parto e parto/nascimento é um período de grande criticidade e sofrimento, quando ficam atentas a todos os sinais e manifestações relacionadas ao trabalho de parto/parto e à criança, respondendo prontamente às solicitações, e desejosas em identificar sinais da sobrevida do filho. A não previsibilidade do desfecho, toda a tensão e agitação desencadeada neste momento para encontrar a melhor solução são de grande sofrimento e parecem durar uma eternidade, a vida é vivida em instantes intermináveis e com grande tensão e dor. 


\section{Subtema: Tornando-se mãe}

O amar e o processo de ser responsável pelo bem de alguém iniciam-se na gestação e mobilizam a mulher a ter ações orientadas para o filho. Os sinais identificados para se dirigirem ao hospital são concebidos como algo de errado. Sabem que um parto/nascimento antes do tempo representa riscos, principalmente de morte, e a notícia de que o filho está na UCIN traduz sobrevivência, existência do filho, certificação de que é mãe, marco de que a maternidade foi concretizada e está aí para ser vivida.

Uma nova preocupação já se manifesta, sai das margens de suas reflexões e passa a organizar seus pensamentos e suas ações: como a criança reagirá frente ao nascimento prematuro e como ela (mãe) conseguirá estar com o seu filho. Ela deseja estar o mais precocemente possível junto do filho, ter ações junto dele. Algumas mães, apesar de desejarem vê-lo não conseguem. Estão paralisadas diante da situação e da ida de seu filho à UCIN. Concebem esta unidade como de risco de vida e temem o fato e o impacto que este todo terá para ela. Estas mulheres buscam estratégias para conseguir vencer esta insegurança, o que vai the permitir estar com o filho na UCIN. No presente estudo, algumas precisaram de um tempo para desenvolver estratégias e habilidades de aproximação com o filho, para ficar diante do filho na UCIN. Uma mãe solicitou para ficar na enfermaria Método Mãe Canguru para, pouco a pouco, entrar em contato com o filho e seu contexto. A imagem e conceito de prematuro e UCIN disseminados na sociedade estão diretamente atrelados à criticidade, ao risco de vida, à instabilidade, à morte. Mães diferem-se nas possibilidades de enfrentar esta realidade, bem como em experiências anteriores de contato com estes elementos. Esses dois aspectos interagem para determinar o tempo necessário para cada mulher colocar-se diante da realidade do filho. Há aquelas mulheres que, apesar 
de todo o contexto crítico, dirigem-se o quanto antes para a UCIN e já vão ficando perto do filho o maior tempo possível, embora suas condições físicas e emocionais sejam limitadas para tanto. Elas sentem-se debilitadas, mas a necessidade de estar com o filho é maior e faz com que fiquem junto dele, já querendo integrar-se ao contexto. Há outras que precisam ser paulatinamente introduzidas à realidade e precisam de algum tipo de apoio, como ter alguém junto no(s) primeiro(s) contato(s), ter certa privacidade neste primeiro momento, ou, como uma das mães do estudo, ter a liberdade de ir e estar quando quiser junto do filho, o que conseguiu pela vivência na estada na enfermaria do Método Mãe Canguru. Em outras palavras, entrar em contato com o prematuro e a UCIN é um dos primeiros desafios a serem transpostos a fim de suprir sua necessidade de estar junto do filho para exercer proteção.

Desde o momento que ela nasceu prematura, com $1,260 \mathrm{Kg}, 0$ que acontece, eu estou... ...De principio quando eu recebi alta para ir embora, eu não conhecia o pré-natal do Leonor, eu quis ficar, conversei com a assistente social e quis ficar mais um tempinho, foi quando eu peguei a primeira etapa do Canguru para eu ficar mais calma e não entrar em depressão, num estresse, num nervosismo, que a aí o nervosismo tira a gente do serio e ía afetar em casa. E nem ia conseguir me dispor do tempo pra ficar no hospital internada, né? Conclusão, me internei por quatro dias, fiquei aqui, conheci mais o pessoal da equipe, fiquei mais segura. Porque eu acho que o importante é também ter segurança, tanto naquele que você deixa em casa, tanto no que fica aqui.(mãe 4)

No caminho eu fui pensando que era cedo para ele vir e ao mesmo tempo pensava que talvez ele não estivesse vindo, era só mais um susto. Na verdade não era, ele estava vindo mesmo, eu percebia isso, o problema era acreditar, aceitar. Eu não queria que nascesse prematuro, já imaginava todas as 
complicações ou até que ele pudesse não ficar vivo. É horrível, muita tensão, muita tensão. Eu não queria que viesse prematuro, a gente vê as histórias, é sofrido, é duro demais para a mãe. Fica na UTI, fica cheio de aparelhos, eu não queria isso para ele, não sabia se eu ia conseguir também ficar com ele, ver ele lá sofrendo, quase morrendo. Tive muito medo, era dor e medo junto. Não via a hora de chegar no hospital e a tensão acabar. É muita tensão. Tensão até que você sabe que está vivo, que agora seu filho já está sendo cuidado. Eu queria logo ouvir isso, mas só fui saber que estava tudo bem já no alojamento conjunto. A enfermeira entrou e falou assim que você achar que dá, você já pode ir na UCIN, seu filho está na incubadora 10. Nem esperei ela falar direito, falei, eu quero ir já, podemos? Você vai comigo, né? Eu não queria estar sozinha, dá medo da gente ficar muito nervosa e pumba, desmaiar. Quando vi ele lá, chorei, era meu, estava lá, todo magrelinho, até era feinho, mas era meu. (mãe 8)

Este tempo transcorrido até o nascimento da criança e a sua ida à UCIN é dependente das significações atribuídas pela mulher à maternidade, prematuro, papéis dos familiares e UCIN. A incerteza faz-se presente e determina certa dúvida e postergação da maternidade. À medida que as coisas vão se concretizando, a incerteza é aliviada e há o investimento por parte da mulher em ações para continuar ou tentar continuar seu investimento na maternidade, na proteção do filho, na sua presença junto dele.

O ambiente que acolhe a mulher ao longo dos processos que antecedem o parto/nascimento pode interferir no sentido de favorecer ou não a ampliação de suas ações maternais. Tudo depende da sensibilidade dos profissionais envolvidos em oferecer informações e ter atitudes para manter a mulher integrada à situação e ao filho. Neste sentido, as mulheres deste estudo mencionaram ser as informações sobre a criança, o favorecer contato visual com a filho na sala de parto, ter pessoas de sua 
confiança próximas durante o parto e nascimento, ações que as auxiliam a ir se aproximando da prematuridade e da realidade dos cuidados críticos e ir criando estratégias e habilidades para suprir sua necessidade de estar junto do filho o quanto antes.

Eu queria ir lá, ver ele, mas tinha medo, tinha medo do que eu ia encontrar, se eu ia agüentar. A gente só ouve coisas ruins de UTI. Eu acabei pedindo para meu marido ir ver primeiro e falar para mim como era e como ele estava. Chorei muito quando ele contou, queria ir lá. Demorei dois dias para ter coragem de ir. Ficava pedindo para meu marido e as enfermeiras irem lá e me contarem as coisas, só depois de dois dias é que consegui ir. Tinha medo de não agüentar, de ficar assustada, de não agüentar. (mãe 10)

Identifica-se que o resgate dos momentos anteriores ao parto e nascimento sinalizam para as mulheres/mãe o quanto investiram para o bem estar do filho, o quanto lutaram para que o desdobramento fosse positivo. Explicita o esforço e dedicação da mulher em relação ao seu filho, o que sedimenta em seus conceitos estar fazendo papel de mãe. Por isso, este resgate influenciará os momentos vividos na UCIN e são importantes para a mulher revivê-los em suas memórias.

\subsection{TEMA: PROTEGER O FILHO}

O momento inicial da trajetória com o filho na UCIN é de grande preocupação e tensão para a mulher e está na dependência da situação clínica do prematuro, do seu conhecimento sobre a prematuridade, do grau de entendimento e informação detido em relação à situação 
particular do filho, das repercussões (físicas e emocionais) do parto prematuro sobre a mãe. São momentos vividos em um contexto pouco propício: foi separada precocemente do filho; tem um filho prematuro na UCIN; vai recebendo inúmeras solicitações, informações e recomendações; vive um forte cansaço e é abalada com os eventos; muitas vezes, nem imaginava passar pelo parto prematuro e vive o inesperado da situação.

Apesar de estar transtornada com os fatos, sentir-se sem controle, tem a necessidade de começar a responder à situação, agir em prol do filho, precisa garantir ao filho o melhor cuidado. Assim, lança-se em ações para aproximar-se do filho, fazer-se presente a fim de exercer ações de proteção.

$\mathrm{Na}$ condição na qual se encontra, vivendo a maternagem sob a pressão dos acontecimentos, proteger é necessidade materna manifesta por meio de ações como atitudes de carinho, de tentativas em conseguir cuidar do filho, ficar mais próxima dele, ali na UCIN, participando dos acontecimentos e lutando para ser integrada a este mundo. Os subtemas estar junto do filho e agir em prol do filho integram esta unidade temática.

A gente fica aqui, a gente olha, a gente conversa, a gente coloca a mão, a gente faz carinho e tudo, a gente sabe que é muito importante, que é o mais importante na realidade, é melhor que qualquer remédio - é o amor. Pros pais é frustrante, porque não é o que eu queria, eu queria fazer mais, eu queria dar o remédio, eu queria por o soro, eu queria tirar a sonda, eu queria ele. Eu queria ele, ter a capacidade de estar ajudando ele, dessa outra forma (mãe 5) 
Subtema: Estar junto do filho

Ir à UCIN para estabelecer contato com o contexto do filho e pensar em como estar com ele para garantir o melhor cuidado é uma das primeiras necessidades maternas. As mulheres/mãe querem adentrar no contexto do filho para certificarem-se, verem com os próprios olhos que ele está lá, vivo, que ele superou os momentos iniciais. Frente a essa certificação, querem e precisam estar com o filho para que se criem condições de se tentar desenvolver ações em prol dele, de identificar o que podem fazer por e com ele. Ir à UCIN é necessidade materna realizada o mais precocemente possível, dentro das possibilidades de cada mãe. Essa ida é a estratégia por meio da qual a mãe vai tentando resgatar a proximidade com o filho, garantindo-lhe o cuidado a ele. Ela é, neste momento, o próprio cuidado disponibilizado ao filho, ou seja, sua presença (física e em pensamento) é o cuidado que a mãe consegue prover ou tentar prover a seu filho neste momento.

Às 6 h00 da manhã de um sábado ela nasceu, foi feita a reanimação, ela foi entubada, eu a vi rapidamente na sala de parto e daí ela já foi encaminhada para a UTIN e eu fui para o quarto. Daí por volta das 11 hoo - 12 hoo eu já tinha levantado, já tinha comido e fui lá para vê-la na UTIN. ... ... Daí, por volta de 11 h00-11h30 eu já estava lá para vê-la na isolete e estar lá com ela na UTI. Então foi mais ou menos isso. Não foi uma surpresa, foi bom, foi gostoso ver que ela estava bem, apesar dela estar entubada, foi bom. Apesar dela estar entubada que seria uma coisa estranha para outras mães, mas ela estava entubada por causa do surfactante, então eu sabia que ela estava bem. Eu sabia dos parâmetros, eu sabia de tudo, então para mim, o fato de ver ela lá na isolete mais me tranqüilizou do que me assustou. Para mim foi gostoso saber que nasceu 
pequenininha, que nasceu prematuro, mas que ela estava lá, e era minha.(mãe 9)

Apesar de eu não estar estérica, louca, mas eu estava tensa, em um estado de choque. Eu só fui ver ele... nasceu 9 horas da manhã, eu só fui vir aqui em cima já eram quase 11 horas da noite. Eu não queria vir, eu não estava acreditando no que estava acontecendo, entendeu? Foi um processo de aceitação que teve de ser rápido. Uma coisa é você saber, se preparar, se envolver porque gravidez é um envolvimento, e outra coisa é você não saber, não estar preparada... É chegar ter, ter, e estar nesse estado, o que é pior né (mãe 5)

À medida que o tempo passa, as mães afirmam conseguir assimilar e visualizar a complexidade de suas experiências; elas conseguem integrar as diversas informações e vão compreendendo o que se passa com seus filhos. Uma grande parcela das mulheres apontou os primeiros sete dias como o tempo necessário para se tranqüilizarem, como o tempo necessário para ter consciência do que estão a enfrentar junto com o filho. Assim, foram momentos de grande tensão, em que estavam a explorar e tentar compreender o contexto do filho para pensarem em como se inserir nele.

Descrevem ser a falta de compreensão aspecto limitador para ela responder de maneira própria ao evento. Frente a esta identificação, algumas buscam estratégias para aproximarem-se do contexto no qual estão inseridas, a fim de entrarem em contato, conhecerem, e, de certa forma, iniciar um processo de familiarização com o mesmo.

... É chegar ter, ter, e estar nesse estado, o que é pior né? Aí você vê uma criança entubada, uma criança cheia de aparelhos, parece um bicho de sete cabeça. O primeiro momento é 
monstruoso. Passa assim, todos os pensamentos mais tenebrosos passam pela sua cabeça, as primeiras 24 horas são horríveis, as 48 horas são horrorosas. Você só vai mesmo se acalmando, mesmo, depois do quinto, sexto dia. Você vai se habituando com o aparelho porque você acaba olhando aquelas coisas e você vai aprendendo a ler prancheta, a se envolver com o enfermeiro, a olhar pro médico, perceber isso e aquilo e, é uma rotina, se torna uma rotina, no começo eu não pegava a prancheta depois do quarto, quinto dia a primeira coisa que eu fazia era olhar a prancheta, via como o meu filho estava, porque isso porque aquilo, se tomou sangue, porque não tomou. Você aprende a interagir com o meio que ele está vivendo, no momento o meio dele é este. Essa é a cama que é dele, ali estão os médicos, estão os enfermeiros, eu sou a mãe que fica aqui... (mãe 5)

Neste ínterim, recebem sua alta hospitalar, sendo este um novo momento crítico, uma vez que irão se distanciar mais do filho, e haverá um elemento novo na vivência para ser integrado, ponderado: agora terá de ir e vir à UCIN, agora não mais terá a oportunidade de ir a qualquer momento do dia e da noite ver o filho, estar com o filho.

A alta hospitalar traz a demanda de locomover-se da casa para a UCIN e dela para casa. As mulheres ficam dependentes de alguém ou do serviço de transporte público para a realização deste translado. Algumas mulheres apontaram estar neste aspecto mais elementos a serem enfrentados, tais como a organização do tempo, a questão financeira, e o aprender a lidar com a distância maior do filho, uma vez que já haviam, de certa forma, habituado-se a estar continuamente com ele. Em relação à questão financeira, administram-na recorrendo à assistente social, diminuindo e selecionando os dias de vinda, apesar de desejar estar junto do filho. 
o parto foi cesárea, então ninguém queria que eu me esforçasse muito e nem viesse aqui todo o dia, mas quando eu vi que eu estava conseguindo, eu fui vindo. Eu tive eles na quinta e fui da alta no sábado à tarde. (mãe 7)

Acho que tem uma semana que eu consegui acertar mais isso. $A$ gente até pensa em como fazer, mas quando vai fazendo as coisas aqui e lá, é que a gente vai percebendo quanto tempo elas levam, o que está dando de errado e que tem que mudar, é uma coisa que a gente vai aprendendo ao longo dos dias. Quando a gente não conhece direito as coisas aqui, fica em casa pensando só o pior, eu não conseguia dormir direito, demorava dormir, dormia tarde, acordava ruim, passando mal, então você não consegue pensar direito em nada, você vai tocando o dia, as coisas todas. Você não consegue organizar nada. Eu consegui me organizar mais depois que fui entendendo mais as coisas daqui (UCIN).(mãe 7)

No dia da minha alta, eu saí daqui chorando, chorando muito. Eu não queria me separar das minhas filhas, parecia que eu ia ficar mais distante ainda. Eu até pedi para o doutor para ele me deixar mais, mas ele falou que não dava. Pedi para ele me deixar mais. Deu um vazio muito grande, eu ir embora e deixar as minhas filhas aqui. Ficou aquele vazio dentro de mim. Eu fui pensando, fiquei em casa pensando, chorei, passei a noite inteira em claro, chorando, daí eu pensei, para que que eu vou me preocupar se eu tenho Deus que mora dentro de mim. Se eu não confiar em Deus eu vou confiar em quem? (mãe 12)

Ao longo dos dias na UCIN, todos os seus sentidos captam informações e as registram na sua memória, como na resolução de um quebra-cabeça, até que as peças se encaixem e ela veja o todo. É um processo de tentar compreender, é a ação materna de conseguir integrar 
as diversas informações que vai captando. Simultaneamente, é um quebra cabeça que é mutante, que se modifica e, com isso se desmonta novamente em partes ou no todo. Continuamente a mulher fica a tentar manter as peças integradas ou a tentar unir as peças novamente. Assim, a situação é muito instável, com ocorrência de novos fatos a todo instante, o que demanda energia e disposição constante da mulher.

Em função disto, a toda saída da mulher do espaço da UCIN, ela vive a angústia de poder voltar e as coisas estarem diferentes, tanto para melhor como para pior. A angústia da imprevisibilidade faz-se continuamente presente.

Á tarde a gente vai para casa pensando, aí meu Deus, minha filha já está melhorando. Você acorda no outro dia com vontade de vim para ver se têm mais novidades. É isso, cada dia que passa é uma coisa nova que você vai descobrindo... ...a gente sai para o Banco de Leite e torce lá para estar tudo bem aqui. É sempre assim, um pensar, pensar. (mãe 6)

Eu sempre fico angustiada quando saio, sei lá o que vou encontrar quando voltar. Outro dia eu saí e quando voltei lá estava ele de novo com a sonda. Fiquei triste. Com o tempo fui me acostumando com isto, sei que aqui tudo pode acontecer. (mãe 11)

Subtema: Agir em prol do filho

Todo o processo vivido na UCIN desenrola-se tendo a necessidade da mãe de estar próxima do filho com o intuito de garantir o melhor como 
eixo estruturador desde o início da trajetória de tornar-se mãe de um prematuro na UCIN.

A mulher, seja ela primípara ou multípara, quer ficar junto do prematuro, quer estar lá na UCIN, perto do filho, acompanhando tudo o que se passa com ele. O prematuro é parte da vida da mulher e ela deseja e articula-se para fazer-se presente. Tem como objetivo estar o quanto antes na UCIN, mas respeita até um certo ponto suas próprias limitações, físicas e emocionais. Reflete o quanto conseguirá estar próxima do filho com presença real. Na identificação de um grande risco de não conseguir fazer-se presente, busca estratégias para fortalecer-se, principalmente no que tange seu emocional. Ela pensa no quanto seu filho precisa dela, fato este nutrido pelas falas da comunidade, seja ela familiar ou profissional; ela conversa com outras mães ouvindo suas histórias e percebendo que algo muito similar ocorre com elas também, e, às vezes, até apega-se às histórias mais complicadas do que a sua para sentir-se acolhida em sua dor; ela procura ressaltar para si o quanto seu filho está a lutar e pensa nele como alguém mais frágil do que ela conseguindo ir adiante e ela ali, quase paralisando-se; ela relembra do quanto já agiu em prol do filho ao longo da gestação, e, assim, tem para si que ela precisa continuar, que ela precisa enfrentar a situação. Algumas mães relatam gostar de conversar com as psicólogas, outras afirmam que estas as forçam a viver as experiências fora do tempo delas, como no momento em que dizem "elas parecem querer forçar a gente a ser forte, a ver a situação como esperada". A maior parte das mães que trouxeram aspectos relacionados a esta questão disseram ser as outras mães e alguns profissionais aqueles que são mais "naturais" com elas sendo apreendidos como os que dão forças para elas continuarem.

Não sei se é porque sou nova que a psicóloga vive querendo conversar comigo. Parece que só eu vivo isso de ficar meio triste, de (silêncio) ela toda hora fica querendo forçar eu a ficar 
falando (silêncio) eu não quero falar nada, tem hora que a gente não tem nada para falar. Se eu preciso eu busco. Que nem a (cita o nome de uma auxiliar) eu adoro conversar com ela. Acho que ela sabe mais de mim e dos meus medos do que a minha mãe. Tem que ser assim, tem hora que a gente quer falar e outra que não. É difícil estar aqui, é difícil às vezes ter forças, parece que não vai dar. Quando ele fica ruim, eu fico muito triste. Qualquer um ficaria triste. É triste ver seu filho assim, é triste estar aqui, ninguém quer. (mãe 8)

A presença junto do filho foi caracterizada na forma física e em pensamento.

A presença em pensamento junto ao recém-nascido é continua no cotidiano da mulher, pois a todo o momento ela se vê refletindo sobre o que ela e o filho estão vivenciando. O eixo das reflexões sempre desvela a preocupação da mulher em relação ao que ela está desempenhando pelo filho. Reflete sobre o que o filho está a passar, sempre pensando se ela tem algo de diferente a fazer, algo a mais a melhorar ou a incluir no jeito de estar ali. Preocupa-se em ponderar se está sendo adequada em termos de garantir o melhor ao filho.

Eu vivia pensando nela, aliás, só fazia isso a todo momento. Pensava no que já passou, no que está passando, no que podia passar. Pensava nela a toda hora, a todo instante. Não conseguia fazer outra coisa. Ia almoçar e pensava será que ela continua bem, será que era a melhor hora para eu sair, agora vai acontecer isso, isso, isso. Ficava preocupada em garantir que tudo ficasse bem. Eu tinha uma mãe muito amiga mesmo, a gente se deu muito bem. Eu pedia para ela ficar de olho na Eu pedia para ela opinião, era uma amigona. Não sei mais a gente fica meio sem saber se está fazendo tudo certo. A gente fica pensando, pensando, tentando sempre ver se era assim mesmo que eu devia fazer. Eu ficava só pensando nela, tanto 
quando eu estava no hospital quanto quando fui para casa. O pensamento era sempre na (mãe 10)

Já quando presente fisicamente na UCIN, a mulher vai atrás dos profissionais, de evidências na própria criança, de informações no prontuário e junto às outras mães que ali estiveram na sua ausência para certificar-se de que tudo o que é possível está sendo feito, de que as condutas estão sendo tomadas conforme os planos estabelecidos, conforme os planos que the foram explanados. Não se trata de controlar e, sim, de acompanhar tudo de perto, vendo e entendendo o que está ocorrendo, dando a proteção no sentido de garantir que a atenção e o cuidado individual estejam sendo dispensados.

Você vai se habituando com tudo isso e começa a se soltar. Hoje eu chego e olho a prancheta, olho tudo na incubadora, olho como ele está, pergunto para as enfermeiras como que ele ficou, pergunto para o médico, pergunto para as mães. Eu vou atrás. Eu quero saber como foi tudo, se continua tudo como antes, se mudou alguma coisa, eu pergunto mesmo, olho tudo, não quero nem saber se acham ruim ou não. É importante para mim, então eu vou atrás até descobrir o que aconteceu, Outro dia mesmo, achei estranho dele ter perdido o PICC. Olhei na prancheta só estava que ele perdeu, perguntei para a enfermeira, ela falou a mesma coisa, mas, porque ele perdeu, estava tudo bem com o PICC. Depois descobri com o médico que eles estavam suspeitando que a infecção vinha dali. Porque não me contaram antes? Eu quero saber tudo mesmo, é meu filho, eu quero saber. Não gosto de meia resposta não. Muitas vezes nos dão meia resposta, é horrível, é horrível. Quando você é nova aqui você não vai atrás, depois... a gente sabe como fazer, pergunta aqui, olha ali, até descobrir tudo. (mãe 11) 
Em ambas as presenças - em pensamento ou física - identifica-se ação em prol do filho, constatam-se presenças que partilham com o filho a luta pela e na vida, tendo como eixo o bem-estar. Presenças com a intenção de compreender os fatos para estar com o filho em suas lutas.

Compreender o que está a ocorrer traz tranqüilidade, enquanto que a ausência da compreensão angustia a mulher, a deixa transtornada. A tranqüilidade não significa estar relaxada, não ter preocupações, mas é tradutora da correlação entre os conhecimentos da mulher sobre a situação e o que está de fato a ocorrer, pois somente assim consegue dispor-se para estar com o filho. Esta consonância lhe permite acompanhar o desenrolar de tudo e ter iniciativas para participar. Participar naquilo que de fato identifica como necessário e possível, ao ponderar sobre si e o contexto da UCIN. Repercussão disso é a melhor aceitação das possibilidades de participação permitidas, quando não executa como sujeito da ação cuidados, mas está conectada à ação ao compreender, observar a realização e tentar garantir a melhor execução. É uma compreensão que nem sempre é acompanhada de concordância de sua parte, sendo, porém entendida como a possibilidade momentânea que detém para estar junto do filho. Sua atitude é de tentar ampliar, em termos de sujeito de ação, a sua participação no que faz, sempre a refletir sobre a forma e o tempo para tal fato, sobre e no contexto da UCIN e sobre suas condições para tanto, aspectos que são constantemente ponderados.

Eu venho sempre, todo dia eu estou aqui. Eu não fico sem ver elas. Eu tenho que vir ver ela e olhar, eu não consigo ficar longe delas. Que nem ontem, estava uma chuva muito forte. Eu estava em casa já pensando o que eu ia fazer, se vinha ou não vinha, melhorou um pouco a chuva, já me troquei e vim correndo para ver elas. Eu por enquanto eu estou na minha 
mãe, vai terminar meu resguardo essa semana, quarenta dias, né. Então eu estou lá. E ela já não agüentava ver a minha agonia para vir aqui ver elas. Aí, assim que cheguei, liguei para o serviço do meu marido e falei advinha onde eu estou. Ele já logo falou, com certeza você está no hospital, você não tem jeito, você não consegue ficar sem ver as filhas. Eu falei assim é, você pensa que é fácil para a mãe ficar longe das filhas. Entre 09h30 até 11 hoo eu já cheguei aqui. Daí eu fico até às sete da noite, quando entra o plantão da noite. Aí eu vou embora e vou sossegada porque passei o dia com elas e sei que elas estão bem. Por exemplo, agora se eu quiser ir embora eu até vou, porque eu sei que elas estão bem. Sabendo que elas estão bem eu vou sossegada. Mas, eu gosto de ficar mais, ficar aqui com elas (mãe 12)

Eu preciso vir, vir aqui e ver a minha filha, ver como ela está. Não é ver que ela melhorou, é ver ela, compreende? Eu quero ficar junto, proteger. A gente sabe muito pouco das coisas dela, a gente vai descobrindo porque ouve um enfermeiro falar isso, um médico falar aquilo, tenta perguntar, tenta ficar a par das coisas... ... é difícil, você quer cuidar, fazer, mas não pode ser do seu jeito e nem no seu tempo, é quando eles deixam. Às vezes eu faço, vou, mudo ela de posição, eu já sei ajeitar esses aparelhos. Eu não estou nem aí, às vezes eu sei que ela quer mudar de posição e mudo mesmo. Agora as enfermeiras nem ligam mais. Eu queria fazer tudo por ela mas, não me deixam... é difícil, mãe quer que tudo fique bem que tudo dê certo. A gente fica em cima para ver se está tudo ok. Eu fico mesmo, pergunto, brigo, não quero nem saber o que pensam. (mãe 8) 


\subsection{TEMA: APRENDER}

Administrar as restrições e a instabilidade clínica do filho com o anseio de participar torna a experiência da mulher muito difícil. Apenas após aprender a conviver com estes aspectos na forma que lhe é peculiar é que a mulher vivenciará a sensação de adequação, conceito particular a cada mulher, mas que congrega reconhecer a UCIN como contexto do filho, seus limites e os limites dos profissionais, bem como encontrar ações para fortalecê-la nesse processo. Assim, conceitos vão sendo desvelados a cada experiência vivida na UCIN, e a mulher, após um tempo, percebe que se depara com uma experiência a cada dia, um aprendizado a cada dia, e que deve viver cada dia plenamente. A mulher, ao encontrar realização em algumas ações junto do filho, sente-se mãe. Estas ações nutrem o processo de enfrentamento e ajudam a mulher a sentir-se protegendo e cuidando do filho. A mulher conseguiu aprender e fortalecer-se para o exercício da maternidade por meio dos processos envolvidos com o tornar-se mãe. Para tanto, ela foi aprendendo a lidar com a situação e teve de administrar as pressões, suportar a espera, conviver com as limitações, superar o cansaço, resgatar energias; buscar a espiritualidade.

E, também porque eu nunca tinha passado por isso antes. É uma experiência nova e complicada. Só quem está passando é que sabe. Quem tem um bebezinho na UTI é que sabe. A mãe é que sabe. (mãe 6)

\section{Subtema: Administrar as pressões}

A UCIN, o recém-nascido e sua situação são impostos à mulher de forma súbita. Uma avalanche de informações, tanto via comunicação 
verbal como não verbal, Ihe são transmitidas à medida que ela entra no local de parto e na UCIN, ou seja, no momento exato dos fatos. Como reflexo, a mulher sente-se perdida, com pouca possibilidade de acomodar tudo o que está a ocorrer, mas pressionada (pelos profissionais e pela sua própria significação de responsabilidade pelo filho) a ter de dar respostas. Com isto, fica, inicialmente, bloqueada no exercício de seu papel e o executam de forma reativa o que Ihe é solicitado, como se reagisse aos fatos, querendo acompanhá-los na velocidade com que eles ocorrem.

A impossibilidade inicial de conseguir compreender tudo é tamanha que a mulher não consegue nem conversar a respeito. Algumas externam seu desespero frente à avalanche de fatos e a angústia de não conseguir ter clareza do que se passa por meio do choro, encontrando nele o alívio e o acalento para o turbilhão de eventos a que está sendo submetida. Ele passa a ser a válvula de escape mais utilizada pelas mulheres. Algumas choram só e outras choram para ou com alguém. Chorar é uma das ações que alivia, que tira a âncora que por vezes a impede de integrar as diversas informações que está a receber e/ou a impede de refletir sobre o modo pelo qual consegue estar frente à realidade que, única a ser vivida, deve expressar a maternagem em consonância com seus ideais. Isto se explica pelo fato de esta ação ser uma oportunidade de introspecção, momento em que reflete sobre o todo de sua experiência com o filho, construindo um novo jeito de conceituá-la e, conseqüentemente, de estruturas novas formas de agir.

No começo não foi nada fácil. Eu fiquei muito, muito abalada, muito abalada. Eu fiquei abalada porque eu não esperava ganhar eles tão antes do tempo, tão pequeninhos do jeito que vieram. Eu sabia que eu ia ganhar eles antes do tempo mas, não tão antes e não tão pequeninhos do jeito que nasceram. Pensei que eles iam nascer com $1,5 \mathrm{~kg}$, eu estava muito inchada e sabia que não ia agüentar até o final. O médico já tinha falado para mim. No dia que eu recebi alta já saí daqui muito triste, 
muito triste de ter nascido, de ter que deixar eles aqui, os dois correndo risco de vida... Não dá tempo da gente se recuperar de nada, as coisas vão acontecendo e a gente vai, vai indo, vai seguindo. Uma coisa atrás da outra e a gente só pode ficar muito abalada. Eu fiquei muito abalado, muito mal. Acho que tem umas duas semanas que eu estou melhorando. Eu ficava aqui só chorando, não conseguia conversar com ninguém. (mãe 7)

Neste momento, a família e os amigos mais próximos são recursos que são acessados pela mulher. Ao conversarem sobre a situação, ela busca, pelo dividir, diminuir suas angústias, conseguir ponderar o que fazer.

Estas pessoas, por sua vez, ao dialogarem com a mulher, querem saber sobre a criança e começam a the pedir informações sobre o prematuro, solicitar detalhes de como ele está, do que está sendo feito. Assim, a mulher passa a ser fonte de informações sobre prematuro para estas pessoas, fica a manter as partes em contato, por meio de suas notícias. Como conseqüência, agrega uma nova pressão frente àquelas que já detêm: transmitir aos familiares e amigos, com destaque para o marido/companheiro, detalhes sobre o dia a dia do prematuro e parâmetros tradutores de seu progresso/retrocesso. Apesar de tentar conversar com outros sobre a situação, ela a vive tão intensamente e está tão vinculada ao filho que não percebe e nem consegue partilhar suas necessidades. Assim, continua solitária no seu sofrimento, sob a angústia da pressão recebida por todas as partes com as quais interage, seja ela consigo mesma ou com os outros e o ambiente que a cerca.

o ___ fica e aí, o que você conta? Mal chego em casa ele já está perguntando. Quer saber tudo, todos os detalhes. Eu ligo todo dia para ele depois que o Dr. passa aqui, conto o que 
ele disse, conto quanto ele ganhou de peso, como ele está e, mesmo assim, quando chego em casa é só dele que ele quer saber. E aí se eu não souber responder... (mãe 11)

Chego cansada em casa, mas não consigo desligar-me daqui, fico pensando em como ela está se ela já mamou, penso será que mamou tudo, como será que ela está... é a todo momento eu só pensando nela. Lá em casa o assunto é só ela, o meu marido e a minha sogra me enchem de perguntas, querem saber todos os detalhes, ela sorriu, você carregou ela hoje, quanto ela ganhou de peso, o que o médico falou... é um montão de perguntas. Às vezes eu nem consigo conversar direito.. estou tão cansada precisando descansar um pouco, mas não consigo. Aliás, acho que eu nem lembro de mim direito, estou cansada e só penso em estar aqui junto dela. Acho que todos nós estamos pensando nela, nem percebemos direito o que está acontecendo, só pensamos nela, não vemos a hora dela estar em casa. É difícil, é cansativo, é muito difícil. (mãe 8)

\section{Subtema: Suportar a espera}

Toda vez em que algo está fora dos planos, há sensação de se ter perdido o rumo, de não ter mais um norte, o que desencadeia ansiedade e nervosismo. Como reflexo, a mulher tende a desesperar-se e tenta trazer novamente a situação para um status do qual ela consiga estar próxima, acompanhando o desenrolar dos fatos dentro do que fora apontado como esperado, compreendendo de alguma forma os eventos com o filho. Assim, situações onde a história desvia-se do curso esperado ou quando há a espera da estabilização de algum aspecto na clínica do filho a fim de determinar-se o continuar do curso da história, fazem com que a mulher não conceba sua posição como de proximidade, o que a faz 
se sentir impotente e perdida no meio da situação. Tem de encontrar paciência para esperar. Esperar é angustiante e a coloca em um status tido por ela como instável, sem controle, o que corrobora com a sensação de angústia, de estar perdida e com ansiedade.

quando tive a segurança daqui, de deixar a neném na UTI, então depende da segurança. Eu estava pensando primeiro em mim, eu estava deprimida sabendo que a estava numa UTI, não conhecendo uma UTI, não sabendo como que é ter um prematuro. O pouco que eu estou sabendo hoje, foi o que eu apreendi naqueles dias, no dia a dia com as enfermeiras, com a assistente social, mas eu não tinha... me dava aquela insegurança, com essa idéia de como que é deixar o bebê na UTI. (mãe 4)

a situação mais delicada para mim foi quando o eco confirmou a persistência do canal arterial e daí... isso ela já tinha uns dez, doze dias de vida, até então estava tudo tranqüilo, dentro do esperado, evoluindo dentro do esperado, ganhando peso e tudo mais. Daí, com a persistência do canal arterial, então veio, talvez, a necessidade de uma cirurgia, teve de fazer a restrição da alimentação, da nutrição. Então ela já não estava ganhando peso com a velocidade que ela vinha ganhando, até porque era necessário, entrou com alguns diuréticos, para ver se ela conseguia fechar esse canal arterial sem precisar fazer cirurgia e sem utilizar a indometacina que também tem seus efeitos colaterais, então só fazendo a restrição e o uso do diurético. Então na verdade esse foi o momento talvez para mim mais angustioso, porque por mais que você conheça todos os procedimentos você sabia o risco de uma RN prematura passar por uma cirurgia, e, ainda uma cirurgia cardíaca. Por mais que você queira, é um momento de tensão, de preocupação. (mãe 9) 
Alcançar a sensação de estar próxima do filho é um processo dependente dos profissionais da UCIN, as mulheres precisam encontrar bem-estar na sua presença, tendo a possibilidade de aproximar-se deles e encontrar um espaço na relação, com vistas a um diálogo aberto. Este é um contexto promotor de ações da mulher para ela sentir-se com o filho, sem mal-estar, e é dependente de sua tolerância e paciência para esperar por esta abertura. Toda vez que consegue esta abertura, sente-se mais à vontade para expor suas preocupações, medos, dúvidas, para pleitear sua aproximação e participação junto do filho; sente-se mais à vontade no contexto da UCIN, tendo maior sentimento de pertença do filho por sentirse de forma mais plena integrada ao contexto do filho.

... eu já estou mais familiarizada por causa das amizades né?, a gente brinca, a gente conversa, não tem aquele tratamento de "você é mãe eu sou médico", então você fica aí e eu aqui, não tem isso não, e isso é ótimo, o tratamento aqui é ótimo, faz você se sentir bem, porque tem lugar que você vai e é um constrangimento danado né, aqui não graças a Deus sempre foi tudo bem. Eu estou bem familiarizada, eu estou doida para sair daqui, mas ao mesmo tempo vou sentir saudade dessa gente (profissionais). (mãe 2)

porque a gente vai se acostumando com as coisas daqui, eles (os profissionais da saúde) vão explicando como é que funciona as coisa, e a gente vai começando a entender como é que funciona cada coisa, os exames, para que são, a gente vai aprendendo, se acostumando e entendendo como é que são as coisas e para que servem. (mãe 7) 


\section{Subtema: Conviver com as limitações}

À medida que vai lutando para sentir-se próxima do filho e perto do mundo do filho, a mulher vai encontrando limitações, cujo enfrentamento lapida conceitos detidos. Destaca-se o confronto de sua crença 'mãe é independente em relação ao filho' com todas as dificuldades para desenvolver ações junto do filho. Assim, ela aprende por meio dos limites que Ihe são postos que mãe tem limites. Alcançar a integração das duas crenças - mãe é independente em relação ao filho, mas com limites inerentes a cada momento - favorecerá à mulher administrar de forma mais pronta e menos sofrida as restrições que vive ao longo da trajetória de tornar-se mãe de prematuro na UCIN.

Eu não desejo isso para todas as mães mas, eu acho que todas as mães que passarem por isso, ela vai olhar a vida com mais simplicidade. De repente a gente percebe que não é tão mulher maravilha. E mãe, tem esta coisa de ser mulher maravilha. E, eu aprendi, sempre fui muito independente, dona de mim dos meus filhos, sempre cuidei dos meus filhos sozinha, gosto de arrumá-los e, aqui eu aprendi que eu não sou mulher maravilha.(mãe 5)

Em relação às restrições encontradas, as mães do presente estudo destacaram os limites de participação como aquilo que mais a abala, repercutindo inclusive em um sentimento de não ter a pertença do filho. Este sentimento corrobora com a sensação de inadequação e de estar sendo julgada em suas ações. Quando esta sensação está presente - o que significa que esta mulher ainda não aprendeu a administrar os limites encontrados -, ela preocupa-se em agradar os profissionais, e esforça-se para acompanhar a situação do filho a fim de ser reconhecida. 
Eu tento ajudar a cuidar delas, pego essa no colo, eu só não posso pegar aquela lá por causa do probleminha dela. Eu estou doida para pegar ela no colo, estou ansiosa para pegar ela no colo. Mas, é assim, fico aqui, olho elas, ajudo no que posso, vou tiro o leite para elas, eu estou tendo pouco leite então estou tirando só para essa daqui porque ela está precisando mais. (mãe 12)

eu tinha que me policiar para não estar invadindo demais um espaço que teoricamente enfim era do auxiliar, era do enfermeiro, tinha que me policiar de não estar fazendo coisas que.. enfim, era minha filha, eram coisas rotineiras para mim, não eram bicho de sete cabeças... Ah, dar um banho em uma incubadora em uma bacia, ah, vou pegar a fralda para trocar a minha filha, eram coisas comuns para mim mas, que eu tinha que fazer com certa ponderação, ver quem é que estava, se ela ficava tranqüila ou não em eu estar fazendo, às vezes pedir para fazer. Levar alguns não, mesmo sabendo fazer... Eu participava dos cuidados da minha filha, mas com restrições, com negociação e observação de como isso repercutia, se não prejudicava a nossa relação, minha e delas. Eu participava dos cuidados dessa forma. (mãe 9)

\section{Subtema: Superar o cansaço}

Dar conta de toda a complexidade da vivência, com a necessidade de administrar suas crenças e seus limites em si própria e no contexto relacional, soma-se ao próprio puerpério, e a mulher relata sentir-se extremamente cansada, tanto física quanto emocionalmente. Porém, ela não se permite sentir cansada, apesar de estar cansada, e esforça-se, além de seus limites, para estar na UCIN. Corrobora para a sensação de 
cansaço o fato de permanecer continuamente conectada em pensamento ao filho, não se desligando mentalmente em nenhum momento. Assim, mesmo quando se afasta fisicamente da UCIN, indo para casa, por perceber que necessita se afastar do ambiente da UCIN, ela permanece na UCIN, em pensamento com o filho, e isso devido ao fato de os eventos irem ocorrendo em cascata - quando é requisitada a responder a algo, imediatamente já está inserida em outro fato, de forma contínua e por vezes concomitante -; devido ao nascimento que ocorreu prematuro com várias turbulências - de repente, o filho vai para a UCIN, a UCIN dá informações, todos querem informações, ações -; em suma, devido à avalanche de eventos que lhe são direcionados para serem por ela vividos.

Verifica-se, por fim, um tornar-se mãe em um mundo mutante que está sempre a exigir, e isso em um momento no qual ela deveria se recuperar do trabalho de parto/parto, com todas as alterações hormonais inerentes ao período, como já observado.

...é cansativo, é cansativo. É cansativo tudo. É cansativo ficar aqui, é cansativo correr o dia inteiro, mas principalmente você ... está debilitada, porque querendo ou não a gente acabou de ganhar neném. Hoje faz 20 dias que eu ganhei o neném. Então a gente não tem um tempo de recuperação que normalmente a gente teria. Então é assim: é o corpo físico e mental, que tem hora que dá uma puxada no ritmo, né!? Que a gente está cansada.(mãe 5)

É, extremamente cansativa. O puerpério já é uma fase cansativa. É uma fase que por si só meia depressiva, o que é normal e tal. E, você ser mãe de prematuro, você não se permite ter o seu período de descanso, por exemplo, você fez uma cesárea, então você tem que ter um certo período de descanso, você não vai ficar subindo e descendo uma escada, 
você não vai ficar fazendo algumas extravagâncias. Então, quando você é mãe de prematuro, você não se permite isso, você tem que estar sempre bem, tem que estar sempre produzindo leite, tem que estar sempre tudo Ok, porque é a forma como você pode estar cuidando dele: é você estar ali na UTIN. Então você não tem tempo de ir para casa, de dizer não, agora eu vou descansar, você não tem esse tempo. Então por exemplo, você vai para o hospital de manhã e você fica até de noite. Você chega sete oito da manhã e fica até dez, onze horas da noite. Tinha muitas mães que chegavam às sete horas da manhã e iam embora só às só às onze horas, meia noite. Então é extremamente desgastante esse fato, porque você não tem um lugar onde ficar, não tem um lugar onde descansar, você tem que ao mesmo tempo se alimentar bem, descansar para você produzir leite, mas ao mesmo tempo, você não tem um lugar para descansar, um lugar para ter essa condição para se alimentar adequadamente porque você passa o dia inteiro fora de casa, então você vai comer fora, então isso é meio complicado, é cansativa mesmo. A experiência de ser mãe de prematuro é cansativa, são 24 horas ligado nele, estando com ele lá ou estando com ele no seu pensamento, pensando sobre o que está acontecendo lá no sentido do dia a dia dele e se continua tudo bem. A gente sabe que eles são assim, hora está tudo bem, hora não. É diferente de ser mãe de bebê de termo, que você sai do hospital com ele de baixo do braço, você vai sofrer mas, vai sofrer em casa. Mesmo que você passe a noite em claro, você está em casa, tem um que divide, você tem apoio de algum familiar, tem o marido, e tal. Você está comendo a sua comidinha que você está acostumada, você tem aquela possibilidade de ah, hoje eu não vou vestir nenhuma roupa especial, vou ficar com a minha camisola, tal. Mãe de prematura não tem isso. Você tem que estar arrumada porque você está saindo, você tem que estar o tempo inteiro fora de casa. Você continua pelo filho. O filho é tudo. Para o filho você não mede esforços, você não mede nada. Saber que ela estava ali, que apesar de saber que ela estava sendo cuidada por outras pessoas, ela não iria estar recebendo o carinho, a atenção da mãe. Então isso te faz continuar e você sabe que você 
precisa manter a lactação, você precisa estar ali para ela e que você ter um contato com ela, estar ali faz a diferença para ela. Então saber isso, é o que te move, é o que te faz estar. Não tem nada que impeça, que te faz... ah, não eu estou hoje eu estou mais cansada, mais com dor, então eu não vou. Praticamente você não percebe isso. É a mesma situação de você estar em uma situação de estresse, em uma situação de limite, você só percebe seu cansaço depois que você passa por essa situação, porque enquanto você está lá, a sua adrenalina te deixa a mil, você está sempre ligada. Então, é o que te faz continuar, você querer que a tua filha esteja o mais rápido possível fora dali te faz continuar, te dá forças. (mãe 9)

Eu me sinto muito cansada, mas vale a pena. É muita correria, vai para lá, passa o dia aqui, estou parada, sem poder fazer nada na minha casa, na minha vida, estou aqui, esperando. Eu fico mais aqui, vou para casa, tomo um banho, janto, converso um pouco, durmo e já volto para cá. Eu não consigo dormir muito bem, eu já levanto naquela preocupação, será que elas estão bem? Eu não desligo daqui. Será que isso, será que aquilo, eu fico direto pensando nas coisas daqui. Isso cansa muito também. Você fica na expectativa sempre.(mãe 12)

\section{Subtema: Resgatar energias}

Para administrar o cansaço, as pressões, suportar a espera e os limites, a mulher busca restabelecer-se, busca energias.

Sair da UCIN é recurso para tentar dar um tempo para si. É recurso para resgatar energias. Esta ação materna só ocorre após certa adaptação à situação vivida, quando suporta melhor o afastamento do cenário da UCIN e permite-se ser um pouco considerada. Porém, cabe destacar que suas saídas, sejam elas para casa, ou para o refeitório, ou para o Banco 
de Leite, dentre outros cenários, sempre trazem a sensação de poder perder a previsibilidade dos fatos relacionados à vida do filho, ou de não poder acompanhar passo a passo, de forma próxima, o desenrolar da vida do filho. Assim, saídas da UCIN derivam em momentos de distanciamento do filho, quando em pensamentos representam o que possa estar ocorrendo, sentindo sempre com alguma ansiedade e insegurança em relação ao que poderá encontrar quando voltar. Distanciar-se do filho é um aprendizado ao longo do tempo e passa a ser tolerado com maior controle ao longo dos dias de estada na UCIN.

Se eu saio eu sempre peço para a (mãe do bebê ao lado) ficar olhando ele, ela também já conhece como ele é. A gente se ajuda, quando ela vai almoçar eu fico aqui com eles, quando eu vou ela fica, poucas vezes a gente sai junto. É sempre bom uma de nós estar com eles, a gente fica de olho mesmo. Quando ela não vem eu até saio, fico mais preocupada, falo com as enfermeiras que eu mais gosto e peço para elas ficarem de olho. Sabe né, eles são sapecas, mexem, arrancam as coisas, vivem dando sustinhos, mas, agora, eu já me acostumei, se eu precisar sair até saio, já consigo sair. Agora, quando vou para casa é sempre ruim, fico pensando nele aqui, penso como será que ele está, como será que ele vai estar quando eu vou voltar. Saio porque eu preciso, preciso comer, preciso dormir um pouco, preciso ir em casa mas, eu prefiro estar aqui com ele, pertinho dele, cuidando para que tudo fique bem, para que tudo dê certo. Ele percebe quando eu estou aqui, ele sabe, eu percebo isso. (mãe 11)

Conseguir estar próxima do filho colabora para sua tranqüilidade e conseqüente adaptação à dinâmica de eventos que está enfrentando. Estar presente lhe permite ir conhecendo o contexto do filho, entendendo e compreendendo o que está ocorrendo e o objetivo das ações desenvolvidas junto de seu filho. Ou seja, à medida que permanece junto 
do filho, por uma necessidade sua, ela aproxima-se do ambiente (estrutura física, dinâmica, pessoas) do filho, absorve informações deste contexto e vai tomando conhecimento de sua própria vida, do filho e dela mesma. No desenrolar deste processo, a mulher vai sentindo-se mais mãe e, paralelamente, vai identificando possibilidades de ampliar sua participação junto da vida do filho, envolvendo-se no pleito crescente de fazer-se sujeito das ações junto do filho.

\section{Subtema: Buscar a Espiritualidade}

Toda vez que perde o controle, não compreende as condutas com o filho ou identifica que a resposta do filho não está adequada ou sai do plano traçado, a mulher fica angustiada, sente a perda de controle da situação e entra em um desespero para conseguir novamente a sintonia com o contexto em termos de ter proximidade e participação sobre as decisões e condutas relacionadas a seu filho. Em todas as situações em que o processo se desvia do plano traçado e visualizado pela mulher, ela vive uma situação concebida como inesperada, e passa a agir para conquistar novamente a posição de mãe, ou seja, ganhar e ter a proximidade suficiente de tudo o que se passa com seu filho, visualizando com clareza todos os aspectos presentes na situação.

Nestes momentos, a espiritualidade também é recurso e a auxilia a conseguir continuar, a conseguir encontrar a serenidade para esperar, para administrar o que não tem por ora explicação ou que nunca terá.

Ai eu estou indo para a igreja dela, né. É a igreja Quadrangular. Antes eu ia na católica, agora estou passando para esta e estou gostando. Estou indo nos cultos, toda sexta-feira tem oração lá na nossa casa. A gente faz. Antes eu ia na católica, todo 
domingo, e às vezes no meio da semana. Agora que eu fui morar com a minha sogra, eu estou indo mais na dela. Estou gostando, estou vendo que está sendo maravilhoso. Não vou deixar de ir não, é uma força. As irmãs da igreja, todos os dias quando eu vou, é na sexta e no domingo, oram para ela sair logo, logo. O pessoal pergunta muito dela lá na igreja, as irmãs, os irmãos. Eu digo, ela está bem, só pegar peso, logo, logo ela vai estar aqui com a gente. Eles falam estamos orando por ela. (mãe 3)

Se eu não acreditasse na existência de Deus eu nem sei como estaria. Eu rezo todas as noites e peço para Deus me dar forças. Mesmo assim, durante o dia, se acontece de eu perceber que estou ficando muito triste, esteja eu onde estiver, eu faço minhas orações e peço ajuda a ele, ergo minha cabeça, respiro fundo e consigo continuar indo em frente de novo. Às vezes a gente está forte, acontece alguma coisinha que já te abala, você fica meio assim. (mãe 7)

... não adianta ficar chorando, tem que rezar, entregar na mão de Deus, ele sabe. Se Deus quis que ela nascesse de seis meses é porque ele tem um plano para a vida dela. Ele que sabe. Deus sabe o que está fazendo. Já pensei, perguntei para Deus porque ela nasceu de seis meses, a resposta, eu sei, está vindo aí. Eu não sei porquê, ele deve ter algum plano na vida da para estar querendo que ela passe por esta situação, deve ter... (mãe 6)

\subsection{TEMA: SENTIR-SE MÃE}

Aquelas ações exclusivas de mãe trazem para a mulher força para continuar, o prazer de sentir-se junto do filho. Com isto, dedica-se 
ativamente a estas ações. Destaca-se neste contexto o leite humano/aleitamento materno. As mulheres têm na ida ao Banco de Leite para a ordenha uma das balizas da organização de seu dia a dia na UCIN. $\mathrm{E}$, aquelas que já estão conseguindo aleitar ao seio materno, realizam-se plenamente nisto.

Outra ação descrita é a oferta de amor, ação que tem peculiaridades quando realizadas pela mãe. As mães identificam que o filho assim sente. Amar realizado pelo contemplar, pela presença, pelo toque. Ações que são percebidas pelo filho diferentemente, por terem sido realizadas pelas mães.

Estas ações recebem singular simbolismo na manutenção do enfrentamento de todas as dificuldades para poderem estar junto do filho.

Fico feliz em ver ela já se alimentando agora, ainda é pela sondinha mas, já é o meu leite. Ela está até ganhando mais peso. Parece mesmo que meu leite ajudou ela a ficar mais gordinha, ela tem ganhado mais peso, hoje ela está com $1120 \mathrm{~g}$, nem parece aquela pequenininha de antes. Ainda bem que eu não desisti, tiro leite todo o dia lá no Banco de Leite, tenho conseguido tirar $30,50 \mathrm{ml}$. (mãe 8 )

O pior é que eu acordo a noite inteira de três em três horas para tirar o leite porque eu tenho muito leite. Eu tenho a mesma rotina como se ela estivesse aqui em casa. Então isto me deixa mais triste ainda porque eu jogo todo o leite fora às vezes. Elas (profissionais do Banco de Leite) me dão um vidrinho e eu encho logo estes vidrinhos e jogo quase todo o restante do leite fora. Então eu fico pensando: 'puxa vida', uma coisa que eu podia dar para a minha filha eu jogo fora. É muito difícil mesmo. Eu não vejo a hora dela sair daqui. ... (mãe 1) 
Tornar-se sujeito de ações junto do filho exige da mulher conseguir que a equipe a reconheça como alguém com capacidade de cuidar do filho. Vê, na presença observadora e no diálogo com os profissionais, contextos para obter mais informações sobre o filho, compreender o que está se passando e nutrir, assim, sua necessidade de sentir-se perto do filho, participando de sua vida. Aprendeu ao longo dos dias em como fazer para que os profissionais confiem nela, a vejam como alguém confiável.

Ao ficar com o filho na UCIN o maior tempo possível, ao aprender, com esta permanência, administrar e tolerar todos os entraves que poderiam vir a impedir tal fato, sente-se valorizada pelos profissionais por saber que estes conferem importância a esses aspectos. Assim, movida por esta intenção, ela aprende, ao longo do tempo, a administrar elementos que possam vir a inviabilizar tal fato. Ela vai reconhecer a necessidade de saber encontrar 0 ponto de equilíbrio entre 0 comportamento esperado pelos profissionais e familiares e seus desejos de manejo da situação do filho à medida que convive no contexto da UCIN. Determinada a vencer limites financeiros e/ou adequar-se às possibilidades financeiras para poder estar com o filho na UCIN, ela vai testando seus próprios limites físicos e emocionais para ficar o maior tempo possível junto do filho e encontra formas de manter a família conivente com esse seu esforço para fazer-se presente na UCIN.

Às $19 h 00$ eu vou embora com o meu coração partido de deixar ela aqui. A minha vida na casa da minha sogra é normal. Eu sempre venho, faço de tudo para estar aqui todos os dias. E quando eu venho... tem dia que eu venho, tem dia que... acho que foi uns três dias que eu não vim por falta de dinheiro para a condução. Mas, aí eu agora estou fazendo esforço para vir todos os dias. (mãe 3) 
Hoje eu não estou nem aí, eu vou perguntando, pedindo, vou xereteando as coisas, observo os outros bebês, fico ouvindo o que os médicos falam e assim eu vou aprendendo mais. Agora já estou adaptada, já sei como fazer, às vezes fazem cara feia para algumas coisas, não gostam que eu mexa nisso, naquilo mas, eu nem ligo. Se tenho vontade mexo mesmo. Eu sei no que posso mexer, eu sei o que estou fazendo, não vou fazer nada que eu não tenha certeza. Eu fico aqui só observando, atenta a tudo e assim a gente aprende, a gente passa a saber o porque de cada coisa. Antes eu não fazia isso, mas agora eu faço e sinto que consigo ajudar mais meu filho, às vezes sou eu que socorro ele, elas nem percebem. Outro dia o pescoço dele é que estava encolhido e o aparelho apitou. Elas estavam demorando eu fui lá e arrumei. Deu certo, o aparelho parou de apitar. Por isso que eu faço mesmo, aquilo que eu sei eu faço, se não eu vou lá e chamo se demorarem muito. Nem ligo para cara feia. (mãe 11)

Aprende, ao longo da luta para participar com a maior proximidade possível da situação do filho, que mãe vive limites impostos pelo contexto em relação ao que almeja e ao que consegue realmente fazer. Percebe que suas intenções de ações junto do filho vão sendo transformadas à medida que tenta realizá-las. Aquelas ações que podem ser realizadas por outras pessoas vão ter de ser mais negociadas para tê-la como sujeito interventor, enquanto que ações que a têm como sujeito exclusivo, com destaque para a amamentação e produção de leite humano, são mais facilmente negociadas segundo seus propósitos. Assim, apesar de querer estar próxima e cuidar do filho, encontra realização nas ações de sua exclusividade, o êxito nelas obtido Ihe dando forças para continuar a lutar com o filho.

Compreender o que se passa com o filho, conseguir acompanhar as decisões da equipe de saúde relacionadas às condutas com ele, identificar que o filho está respondendo de acordo com o que fora planejado e ter 
ações de sua exclusividade é percebido pela mulher como elementos que a mantém próxima do filho, o que a deixa mais tranqüila. $E$ a tranqüilidade permite reflexões e ponderações sobre os eventos que o filho está vivendo, o que repercute no entendimento sobre a necessidade de cada intervenção/ação junto do filho e na busca de mais paciência para esperar os desdobramentos da situação.

Portanto, tornar-se mãe na UCIN envolve aprendizados sobre o contexto no que diz respeito aos elementos constituintes, no que diz respeito aos valores profissionais e institucionais para conseguir identificar o como e o que da identidade materna irá manifestar. Precisa resignificar seu papel de mãe para ir sentir-se mãe. 
Parte III

Discussão dos resultados 
Precisamos descobrir quais intervenções são as mais efetivas para as famílias que estão a sofrer com a doença e como essas intervenções funcionam (Wright \& Bell, p.2)

Maternar abarca práticas de criação e cuidado construídas histórica e culturalmente. As práticas de maternar são determinadas por crenças vinculadas à questão de gênero e, ao longo do século XX estavam estruturadas, quase que exclusivamente, sob a responsabilidade da mulher como uma missão de sua vida. Esta concepção determinava sacrifícios pessoais da mulher para atender às expectativas de criação e cuidado nela depositadas ${ }^{(50)}$.

As mulheres do presente estudo concebem ser exclusividade sua cuidar do filho. Ela ultrapassa seus limites físicos e emocionais, permanece ali junto dele, com a necessidade de apreender e compreender esse contexto a fim de ampliar o seu espaço nele. É um processo difícil, no sentido dos profissionais e das próprias regras institucionais não reconhecerem a mulher vivendo a experiência de tornar-se mãe. Há a expectativas dos profissionais em relação ao comportamento materno, conforme crenças socialmente estabelecidas de ser boa mãe.

A análise das narrativas tradutoras dos momentos iniciais da experiência de tornar-se mãe na UCIN permitiu identificar que a mulher luta para conquistar espaço no contexto do filho a fim de exercer ações projetadas por ela como de mãe. Conquistar seu espaço e conseguir desempenhar ações nele, está dependente dos aprendizados adquiridos no processo. São os aprendizados que determinam uma maior tranqüilidade à experiência, uma vez com a acomodação deles a mulher administra melhor a tensão e a sensação de estar sem o controle da situação. Com isto, ela manifesta-se em suas necessidades e, simultaneamente, negocia a ampliação de seu próprio espaço, sentindo-se cada vez mais mãe. 
É em função do exposto acima, que alguns estudos ${ }^{\text {(51-52-53) }}$ caracterizam a experiência da mulher na UCIN com os termos vinculados a participação e a exclusão; sentir-se visita do filho; de expectadora para colaboradora.

Outros estudos ${ }^{(6,13-14)}$ descrevem as estratégias e os processos vividos pela mulher para aproximar-se do filho e do contexto dele.

Aprender é, portanto, o aspecto que impulsiona a mulher para uma experiência menos tensa de tornar-se mãe na UCIN.

Cabem, após as tematizações observadas, algumas discussões, estruturadas em: importância do período gestacional; os aprendizados e as implicações para a prática de enfermagem.

Importância do período gestacional

Em relação aos momentos relativos ao período gestacional, identificou-se ser o resgate das ações direcionadas ao filho o que propiciou à mulher seu enfrentamento no processo de estabelecer-se no papel de mãe na UCIN. Certificar-se de que sempre teve ações direcionadas ao bem-estar do filho fez com que as mulheres do presente estudo não se paralisassem na busca da identidade materna.

Assim, a interação mãe-filho nos momentos gestacionais e as ações maternas desenvolvidas na gestação para o filho interferem na experiência do tornar-se mãe na UCIN, como apontam outros estudos (13, 53-54). Portanto, investimentos profissionais promotores dos processos familiares para a chegada de um bebê devem ser adotados na prática clínica nesta instância. 
Em revisão da literatura sobre intervenções de enfermagem vinculadas ao processo de tornar-se mãe ${ }^{(54)}$, esta categoria de intervenção foi destacada. As autoras apontaram serem estas aplicáveis ao longo dos três trimestres gestacionais e nos dois trimestres pósnascimento.

Continuando a explorar as narrativas do período gestacional, percebe-se que a mulher diminui a intensidade sobre o que acontecerá no futuro. As narrativas relacionadas ao período gestacional mostram posturas direcionadas ao que está por vir, e, a partir de toda experiência de tornar-se mãe na UCIN, elas não deixam de prospectar o futuro, mas com maior ponderação em termos da amplitude do que esperar. Adquirem consciência da imprevisibilidade do futuro, dos acasos que a vida pode prover, suscitar, da não possibilidade de controle. A mãe aprende que só o tempo é que consumará a realidade e que, sendo esperar intrínseco ao viver, precisa estabelecer espaço para continuar-se a existir. Esse é, portanto, um dos aprendizados que integra a experiência de tornar-se mãe na UCIN, aprendizado que, para a vida, será transposto nas distintas situações por ela vividas.

O parto prematuro é a primeira vivência determinante da construção do significado acima descrito. O nascimento prematuro traz incertezas e preocupações e desvia o curso do processo dos investimentos maternos. Apesar do nascimento prematuro, a mulher/mãe tem a necessidade de estar junto do filho, de sentir-se parte do contexto dele. Esses elementos promovem a luta da mulher em encontrar-se como mãe, a fim de garantir ao seu filho bem-estar e proteção, reflexos da responsabilidade sentida por ela em relação ao seu papel de mãe, o que já se fazia presente nos tempos gestacionais e resgatá-los sedimenta na mulher sua orientação para o maternar. 
Aprendizados

O contexto da UCIN, na figura dos profissionais e na organização de seu funcionamento, pouco reconhece estar a mulher e sua família passando por uma transição no ciclo vital à medida que vivencia com seu(s) filho(s) a necessidade de cuidados intensivos.

A experiência de estar com o filho na UCIN é diferente da experiência de tornar-se mãe, apesar do último processo conter 0 primeiro. Uma das diferenças evidenciadas é a influência do ambiente da UCIN, do aspecto do prematuro, do medo da morte do filho para o processo de tornar-se mãe na UCIN em relação às experiências na UCIN. No processo de tornar-se mãe, eles fazem-se presente sem influenciar com o mesmo impacto o movimento da mãe de maternar. A mulher vive toda a angústia e medo do que pode vir a ocorrer com o filho, mas apesar deles, continua buscando ser mãe. Ela não se imobiliza frente a este sofrimento, medo. Com isto, ações típicas maternas como querer ver o filho, querer estar junto dele, querer participar do que está a ocorrer com o filho, são presentes e manifestas pela mulher, apesar de estarem vivendo o impacto do contexto da UCIN e do aspecto de seu bebê. As ações maternais alteram-se no grau e na autenticidade de sua manifestação ao longo do processo, mas estão presentes e com tentativas de manifestá-las em sua plenitude desde o início de sua experiência de tornar-se mãe na UCIN.

O presente estudo destacou ser o contato visual da mãe com a criança o elemento que desperta e sedimenta na mulher o sentimento de responsabilidade pelo filho, e que a impulsiona a lutar para expressar as funções concebidas por ela como de mãe. 
Cada mulher encontra, em seu tempo, formas para ter o espaço que Ihe assegure a manifestação de seu jeito de ser mãe. São os aprendizados adquiridos ao longo da interação com o contexto da UCIN que favorecerão à mulher expressar o seu jeito de maternar, a expressar de forma cada vez mais próxima do almejado por ela, o seu jeito de ser mãe, jeito este reflexo direto do significado de mãe que a mulher detém e constrói ao longo da interação com seu filho, com o ambiente da UCIN e sua história de vida.

Aprender é um processo pelo qual o sujeito se transforma, extraindo informações do meio em que vive. No modelo socioconstrutivista de aprendizagem ${ }^{(55)}$, defende-se uma perspectiva tridimensional, composta pelo sujeito que aprende, pelos parceiros (outros alunos, professor, dentre outras pessoas) e pela interação do meio em si, construindo a aprendizagem. Os espaços da interseç̧ão desses aspectos são chamados de espaços de diálogos, sendo apontados como condição sine qua non para e da aprendizagem. Aprender é um processo contínuo, dinâmico, aberto e infinito.

Assim, no cenário da UCIN, a mulher, a equipe de assistência à saúde e o contexto da UCIN estão em interação e no encontro de espaços dialógicos podem surgir meios propícios para a aprendizagem ser processada.

Para que exista continuamente aprendizagem, o sujeito precisa inserir-se em um processo cada vez mais pessoal de construção de seus conhecimentos, de desenvolvimento, de ajustes, de renúncia aos conhecimentos em função das representações que faz nas situações que tem que enfrentar ${ }^{(55)}$.

No presente estudo, a mulher luta para a construção cada vez mais pessoal do papel materno e, vai com isto, tornando-se facilitadora e promotora de seu próprio processo de tornar-se mãe. Vai, paulatinamente, reivindicando e conquistando a autonomia para exercer 
seu papel de mãe. É um processo vivido de certa forma solitariamente, em que ela vai assumindo a busca daquilo que precisa para obter consonância com a identidade materna que vislumbra ter.

A partir do modelo socioconstrutivista de aprendizagem ${ }^{(55)}$, três dimensões colocam-se em interação a fim de suscitar aprendizados. Cada dimensão está sob diferente controle, porém intimamente interligadas pelo processo interacional estabelecido entre elas. Uma dimensão está ligada à organização das interações sociais e das atividades vinculadas ao aprendizado, estando sob o controle de quem intermedia o processo; outra, está ligada à organização da aprendizagem e está sob o controle de quem aprende; e, a terceira dimensão conecta-se à organização do objeto de aprendizagem, à interação do aprendiz com o meio onde estão os objetos e as situações para a aprendizagem.

Podemos dizer, pelos resultados obtidos, que as duas últimas dimensões mencionadas acima são buscadas pela mulher e que a primeira dimensão ocorre de forma mecanizada e rotineira, sem a devida percepção dos facilitadores do processo (profissionais da saúde) da individualidade de cada sujeito com o qual interagem no exercício profissional.

Assim, o tornar-se mãe sob o contexto da UCIN é vivido como reflexo do instinto e luta materna. A busca por informação, pelo conhecimento, pelas aprendizagens, são impulsionadas pelo sofrimento da mulher em querer ser mãe de seu filho, em querer ter o espaço para manifestar sua identidade materna. Trata-se de um processo solitário, pois somente ela tem consciência de suas necessidades. Os profissionais e os familiares, pessoas com as quais usualmente está em interação, têm a criança como foco e depositam expectativas na figura da mulher. Os familiares do presente estudo utilizaram-na como quem intermedia o contexto do prematuro com o contexto da família/casa. A mulher tinha de saber detalhes, informações com suas respectivas justificativas em 
relação a condutas e evolução da criança. Os profissionais têm a mulher, parafraseando Angelo ${ }^{(31)}$, como fonte e receptáculo de informações, e esperam dela ações sempre vinculadas à criança. Querem instruí-las a cuidar da criança de forma pré-estabelecida e formatada por eles.

Assim, o meio que acomoda a mulher na experiência de tornar-se mãe é adverso, em termos de existir toda uma nuance de sofrimento em relação ao estado da criança, à falta de espaço para a mãe e falta de reconhecimento da pessoa da mãe com expectativas e ações direcionadas a ela sem congruência com o que ela está a passar. Como reflexo, o sofrimento é característica do meio no qual a mulher encontra-se imersa para viver a aquisição do papel de mãe.

Vergely ${ }^{(56)}$ afirma ser o sofrimento um fenômeno humano que traz a sensação de sentir-se mal, o que traduz uma aspiração do ser humano pela existência, pela manifestação das possibilidades nele contido. Outro sentido do sofrimento está no suportar, em assumir a prova do tempo e da vida.

A sensibilidade remete à vida, que reage contra o que a agride por um grito, alertando-nos sobre o fato de que há o intolerável na vida. A paciência remete à virtude que se esforça para ser mais forte do que aquilo que agride, precavendo-se da tentação de agredir por sua vez e de fazer assim o jogo da agressão.

Sem paciência, a sensibilidade que reage ao mal acaba por fazer mal a si mesma ao desesperar-se, ou por fazer mal para vingar-se. Sem sensibilidade, a paciência que se esforça pra superar a adversidade acaba por resignar-se a esta, abandonando-se (o que é uma maneira de fazer mal a si mesmo), ou deixando fazer mal (o que é uma maneira de pactuar com ele) ${ }^{(31, \text { p. 161-162). }}$ 
Assim, esse autor destaca que a sensibilidade precisa de paciência e a paciência de sensibilidade, que, juntas, transformam o homem, fazendo dele um ser verdadeiro, com o sentido de sua vida.

A mulher busca, na luta contínua pelo seu espaço de mãe, ter a paciência para lidar com os limites encontrados para o exercício da maternagem e utiliza progressivamente da sensibilidade para encontrar o caminho de ampliação de seu espaço para construir sua identidade materna. À medida que vai conhecendo o contexto da UCIN e seu filho, ela dialoga em suas reflexões o como ir negociando sua presença e a manifestação autêntica dessa. Alcançar a autenticidade no seu maternar fomenta cada vez mais a construção de sua identidade de mãe na UCIN e a ajuda a estar com o filho ao longo de todo o tempo que ali precisarão ficar.

A mulher encontra, a partir da interação com a UCIN, por meio das observações, de suas reflexões, o jeito de negociar espaço para fazer-se mãe de seu filho. É encontrar o espaço no não-espaço.

Em estudo de Enfermagem ${ }^{(51)}$ cujo objetivo foi similar ao nosso, ou seja, descrever a experiência da mulher em tornar-se mãe enquanto seu filho estava na UCIN, as autoras observaram que, ao longo do processo, as mães tornam-se parceiras da equipe de assistência, com modificação de conceito em quatro domínios: foco, pertença, cuidado e voz. Em relação ao foco, alteram sua ênfase do ambiente da UCIN para a criança; no que diz respeito à pertença, trazem a mudança do conceito "bebê dos profissionais da UCIN" para "meu bebê"; já quanto à participação nos cuidados, a mulher torna-se progressivamente mais participativa, o que repercute na substituição de uma atitude mais silenciosa para uma que advoga, conceito destacado no domínio voz. Estes domínios refletem a ampliação do espaço para a mulher exercer seu papel de mãe, o que também fora encontrado no presente estudo. Consonância existe em 
todos os domínios, porém definidos no nosso estudo com outras palavras. No que diz respeito ao domínio relacionado à atitude da mãe de advogar pelo seu filho, o nosso estudo nomeou como alcançar a autonomia e autenticidade para exercer seu papel de mãe. As alterações nos focos do sentimento de pertença e das atitudes de cuidado estão expressos nos meios utilizados pela mulher para apreender o contexto da UCIN e o filho a fim de identificar o como criar seu espaço junto dele. As mulheres de ambos os estudos foram lutando para terem espaço na vida dos filhos, no sentido de participar, cada uma delas a sua definição de mãe da vida do filho.

Cabe destacar que os parceiros encontrados pela mulher no processo de tornar-se mãe estão representados principalmente por outras mulheres que partilham de situação similar e na própria mulher como objeto para si. Ou seja, nos diálogos interiores (entre o mim e o eu) é que as mulheres foram encontrando novas significações e atitudes para lidar com as limitações encontradas. A mulher, na sua própria pessoa, foi o recurso mais importante para si. O processo é solitário neste sentido, uma vez que apenas ela é que passa a reconhecer e valorizar suas necessidades e, com isto, lança-se em busca de soluções, o que traduz o processo de enfrentamento para experienciar o tornar-se mãe na UCIN.

Implicações para a prática de enfermagem

Os profissionais poderiam facilitar o processo desde que tivessem a sensibilidade para o que está a acontecer: uma mulher tornando-se mãe, uma família alterando em seu estágio no ciclo vital, buscando uma nova identidade.

Nystrom; Ohrling (57) apontam a necessidade de intervenções de enfermagem focalizadas na transição para a parentalidade, com destaque 
para o apoio do enfermeiro no que tange a questão da sensação de segurança na experiência de tornar-se pais.

Mercer \& Walker (54) destacam, nas discussões da revisão sistemática que realizaram sobre intervenções de enfermagem para promover a experiência de tornar-se mãe, a importância dos enfermeiros selecionarem as intervenções a partir do conhecimento das individualidades de cada pai que estão a auxiliar. Exemplificam que mulheres com menores conhecimentos beneficiam-se dos programas educativos, enquanto que mães já detentoras de maiores informações e competências querem cuidados menos intensivos e diretivos. Assim, a realidade de cada mulher é que determinará o que e como agir, e não uma pronta formatação de ações para promover, apoiar a experiência de tornar-se mãe.

Mercer ${ }^{(33-34)}$ afirma ser uma intervenção de enfermagem o apoio à mãe na obtenção e manutenção da autoconfiança em suas habilidades, no senso de controle e sentimentos de conexão com seu recém-nascido. Aponta ainda a necessidade do enfermeiro avaliar os recursos maternos e prover suporte informacional reforçando suas habilidades de assumir cuidados e de interação com seu filho. A importância da informação também é destacada por Hurst ${ }^{(14,17)}$ e Lawhon ${ }^{(58)}$ que a concebe como elemento fundamental para o desempenho do papel materno.

A aquisição de informações é a principal estratégia utilizada pelos pais para ganhar controle e administrar as incertezas ao longo da situação de hospitalização do filho. Destaca que quando a incerteza diante da situação é alta, os pais lutam para conseguir mais e mais informações ${ }^{(59)}$.

Recomenda-se a transmissão das informações por diferentes meios a fim de ampliar e favorecer sua compreensão ${ }^{(13)}$. Dixon ${ }^{(59)}$ encontrou ser o foco do diálogo estabelecido pelos enfermeiros com os pais, o aspecto que compromete a compreensão da situação, em função de estar 
pautado no perguntar e no dar comandos, recomendações de como agir, fazer.

As informações são partilhadas nas interações, sejam elas formais ou informais, o que envolve a compreensão dos significados, sentimentos, preocupações, dificuldades únicas de cada mãe (13-14, 17, 33-34). A comunicação é elemento chave na relação profissionais-famílias porque os pais são dependentes do conhecimento e experiência profissional para estabelecer seus significados ${ }^{(60)}$.

Os profissionais não foram mencionados nas narrativas maternas como recurso promotor da aquisição de informações. As mulheres buscam solitariamente as informações, não encontram nos enfermeiros parceiros para sua experiência ${ }^{(57)}$.

Ocorre de poder estar as mães vivendo o que Dixon ${ }^{(59)}$ aponta em seu estudo de revisão: antes da ocorrência de uma relação colaborativa entre pais e enfermeiros, os pais precisam tornar-se mais confiantes em si próprios, alterarem a percepção que eles têm de si em relação à sua capacidade de advogar pelo seu filho. Apenas nessa condição há a possibilidade de abertura para um relacionamento mais próximo, onde a confiança pode ser estabelecida.

Em estudo ${ }^{(61)}$ cujos objetivos foram compreender a experiência de interação da família que vivencia a doença e hospitalização da criança, identificou-se existir a necessidade dos pais de sentirem-se acolhidos e seguros no ambiente hospitalar, com valorização de ações do profissional de estar com a família, compartilhando a experiência e o cuidado da criança.

As mulheres do presente estudo, ao longo da experiência de tornarem-se mães, lutaram justamente para encontrar espaço que Ihes permitisse sentir-se junto do filho, com uma proximidade que trouxesse a certeza de compartilhar da situação, da vida do filho. Não destacaram em 
suas narrativas terem encontrado profissionais facilitando este processo, visto que relatam suas vivências de forma a dar o entendimento de lutarem por isso praticamente sozinhas.

O estudo citado anteriormente ${ }^{(61)}$ destaca a promoção de um contexto relacional acolhedor, onde a família encontre a sensação da segurança e, assim, consiga desenvolver novas capacidades e recursos de enfrentamento como elemento fundamental do cuidado.

As mulheres do presente estudo buscaram segurança no ambiente e na aquisição do papel de mãe com estratégias e iniciativas próprias, com destaque para a solicitação de uma delas para ficar na Enfermaria Mãe Canguru. Ou seja, os movimentos para a aquisição da segurança para ir tornando-se mãe, nas narrativas das mulheres desse estudo, partiram delas próprias, reflexo do sofrimento vivido no ambiente não-familiar da UCIN e da sensação de não estarem sendo mães. Esse sofrimento, ao exigir que se identificasse o modo pelo qual assumiriam sua identidade de mãe no contexto adverso da UCIN, as impulsionou a aprender, por mobilização própria, como fazer.

As mulheres deste estudo reafirmam o que Silveira ${ }^{(61)}$ destacou:

O sentimento de segurança e o senso de competência da família são profundamente afetados pelas atitudes dos profissionais de saúde. No entanto, pode ser alcançado por meio dos próprios esforços da família (61, p. 140).

O sofrimento tem qualidades que redimem e transformam, principalmente por acionarem virtudes como o da paciência, da esperança, da humildade, que tendem a engrandecer o ser humano, modificando-o, geralmente, para melhor. 
Os aspectos do sofrimento que podem ser pronunciados precisam encontrar ao menos a escuta para talvez serem reconhecidos e partilhados. $O$ enfermeiro necessita assumir o enfrentar o sofrimento com aqueles que estão sob seus cuidados, e oferecer o espaço para que sejam exprimidos já seria uma importante intervenção ${ }^{(62)}$.

Abordar o sofrimento implica em falar sobre espiritualidade e crenças, três elementos entrelaçados e intimamente interrelacionados em cuja intersecção se explicita o sentido da vida ${ }^{(62)}$.

O sentido da maternidade é encontrado pela mulher à medida em que ela define o filho e suas necessidades, funções de mãe e espaço na UCIN para a mãe. Definir determina conceitos para agir, ações que vão sendo cuidadosamente construídas e negociadas a fim de se ter a certeza de encontrar a possibilidade de colocá-las em prática. São as informações que ofertam à mãe o estabelecimento de significados para ir tornando-se mães, para sentirem-se seguras no desenvolvimento de suas ações maternais.

Sentindo-se segura em sua habilidade de mãe, a mulher vai sendo cada vez mais autêntica consigo própria na expressão de sua identidade materna. As crenças são reconstruídas na medida em que vivem o sofrimento para ser mãe. O amor pelo filho, o esforço para tentar suportar e ultrapassar as adversidades encontradas para maternar, mantêm a mulher na luta pela sua identidade. As mulheres têm a necessidade de encontrar sentido para o sofrimento vivido, o que as conduz ao domínio espiritual. A espiritualidade é a resposta mais profunda ao sofrimento. As mulheres do presente estudo explicitaram ancorar-se na espiritualidade para ir adiante quando os meios racionais não conseguiam dar respostas e explicações, acalentá-las em sua dor, mantê-las com energia para continuar a lutar.

Fruto de toda a pressão vivida na experiência do tornar-se mãe, a mulher vive a sobrecarga. Esta é o reflexo das exigências e expectativas 
depositadas na sua figura, tanto pelos profissionais como pela família, bem como dela própria para consigo, o que repercute em seu desgaste emocional e físico. Apesar da sobrecarga, a mulher mantém-se atenta a estas solicitações e expectativas, embora saiba estar no seu limite. Acreditamos que a crença de que mãe tem que estar junto, tem que fazer pelo filho, a mantém nesta atitude, negando a si própria em prol do filho.

Shin e White-Traut ${ }^{(53)}$, partir de uma análise de conceito da transição para a maternidade na UCIN, também identificam um redemoinho psico-emocional como um de seus achados, com a manutenção de uma expectativa positiva materna em relação ao desdobramento da situação. Outros estudos sobre maternidade também descrevem como tumultuada esta fase em função da sobrecarga vivida pela mulher ${ }^{(57)}$.

Shin e White-Traut (53) destacaram ser o processo tempo dependente, o que vai ao encontro do observado em nosso estudo, bem como destacam que a maternagem é exercida no limite de sua definição, como mostra o termo por eles empregado "hovering around the edge of mothering". As mulheres desse estudo lutam para ultrapassar esse patamar, mas também encontram limites e restrições para o pleno exercício de sua maternagem. Tal observação vai de encontro a observação de Belli ${ }^{(6)}$ de que superar as barreiras representa um movimento em direção ao desenvolvimento da maternidade. Esse movimento é possível a partir da (re)significação das representações maternas sobre os elementos constituintes da UTIN.

Concordamos com Belli ${ }^{(6)}$ que cabe aos profissionais promover espaço e oportunidade para que as (re)significações ocorram, no caso do foco de nosso estudo, (re)significações no que tange o papel materno. As informações foram a principal mediadora dessas (re)significações, elas oportunizaram os aprendizados. Ocorre que as mulheres não encontraram parceiros para adquirirem tais informações assim, buscaram-na 
solitariamente, de forma bastante sofrida, o que repercute no cansaço físico e psicoemocional. Sensação essa muito forte nos momentos iniciais da experiência de tornar-se mãe na UCIN, já que é a própria mulher que irá, após os aprendizados, encontrar a forma como administrar os conflitos de interesse e de espaço. Tais achados sugerem que muito da tensão e dificuldade vivenciada pela mulher nos momentos iniciais de sua permanência junto do filho na UCIN poderia ser amenizado caso as mães encontrassem enfermeiros sensíveis para com suas experiências e preparados a intervir junto da mesma. Um relacionamento colaborativo, onde as informações são apontadas como primordiais e fortalecedoras da mulher em identidade, foi desvelado como importante intervenção junto às mulheres/mães.

Cabe repensarmos no preparo do enfermeiro para estar com mães de forma a colaborar no enfrentamento da situação que estão a viver. Robinson (63) encontrou os seguintes aspectos para um estar do enfermeiro com possibilidade de ser terapêutico junto às famílias/mães:

- Escuta curiosa e atenta, quando o enfermeiro, ao dialogar, demonstra orientar-se pelo que está sendo dito pelas famílias/mães;

- Atitude de compaixão recebida por parte de alguém que lhe é estranha, isto é, a família/mãe sente que o enfermeiro foi tocado por sua situação, com demonstração de interesse e envolvimento com essa, mas não se envolve com o problema. Envolve-se no processo de resolução do mesmo de maneira objetiva e imparcial;

- Atitude não hierárquica, onde os enfermeiros colaboram com as famílias/mães, reconhecem as expertises e auxiliam para o uso das mesmas; 
- O enfermeiro disponibilizando-se como espelho para as forças familiares/maternas.

Concluímos que quanto mais informados os enfermeiros estiveram sobre a situação de cuidado que estão a partilhar, maior a probabilidade de oferecerem intervenções efetivas na particularidade de cada experiência.

A experiência de tornar-se mãe na UCIN é vivida de forma solitária, com muito sofrimento e desgaste para a mulher para estabelecer-se como mãe. Corrobora-se com as conclusões de Reid ${ }^{(64)}$ no sentido de que a maternidade na UCIN é postergada. Poderia ser diferente em função da presença disponibilizada pelos enfermeiros às mães.

A sensibilidade dos enfermeiros para a questão, bem como o preparo dos mesmos para estarem com as mães e poderem intervir junto a elas precisam ser mais abordadas no ensino, pesquisa e processos de educação continuada na prática clínica a fim de podermos oportunizar a estas mulheres um cuidado humano, um cuidado que alivia o sofrimento e que gera a cura.

Esperamos ter despertado reflexões e colaborado com o corpo de conhecimento disponível neste âmbito, podendo assim oportunizar um (re)significar dos conceitos de cuidar, enfermeiros e mães detidos por aqueles que estiveram a apreciar nosso estudo. 
Referências 
1. Lupton D, Fenwick J. They've forgotten that $I^{\prime} m$ the mum: constructing and practising motherhood in special are nurseries. Social Science \& Medicine 2001; 53:1011-1021.

2. Fenwick J, Barclay L, Schmied V. Activities and interactions in level II nurseries: a report of an ethnographic study. Journal of Perinatal and Neonatal Nursing 1999; 15(2): 49-64.

3. Gomes MMF. As repercussões familiars da hospitalização do recémnascido na UTI neonatal: construindo possibilidades de cuidado. [Tese]. São Paulo(SP): Universidade Federal de São Paulo; 1999.

4. Lamy ZC. Unidade Neonatal: um espaço de conflitos e negociações. 2000. [Tese] Rio de Janeiro (RJ): Fundação Oswaldo Cruz; 2000.

5. Scocchi CGS. A humanização da assistência no bebê prematuro: bases teóricas para o cuidado de enfermagem. [Livre docência]. Ribeirão Preto(SP): Escola de Enfermagem de Ribeirão Preto da Universidade de São Paulo; 2000.

6. Belli MAJ. Mães com filho internado na UTI Neonatal: um estudo sobre representações sociais. [Tese]. São Paulo(SP): Escola de Enfermagem da Universidade de São Paulo; 2003.

7. Lamy ZC. Estudo das situações vivenciadas por pais de recémnascidos internados em unidade de terapia intensiva neonatal. [Dissertação]. Rio de Janeiro(RJ): Fundação Oswaldo Cruz; 1997.

8. Affonso DD et al. Stressors reported by mother of hospitalized pemature infants. Neonatal Network 1992; 11(60): 63-70.

9. Griffin T, Wishba C, Kavanaugh K. Nursing intervention to reduce stress in parents of hospitalized preterm infants. Journal of Pediatric Nursing 1998; 13(5): 290-295. 
10. Barros L, Brandão A. Preocupações, dificuldades e perturbação emocional em pais de bebês hospitalizados numa unidade de neonatologia. Psicologia: teoria, investigação e prática 2002; 2: 265276.

11. Carvalho RMS de, Patrício ZM. A importância do cuidado presença ao recém-nascido e de alto risco: contribuição para a equipe de enfermagem e a família. Texto-contexto Enf. 2000; 9(2): 577-589. pt.2.

12. Caetano LC. Vivendo o método canguru - a tríade mãe-filho-família. [Tese] Ribeirão Preto (SP): Escola de Enfermagem de Ribeirão Preto da USP; 2004.

13. Bialoruski MA, Cox $C L$, Hayes $J A$. The nature of attachment in a neonatal intensive care unit. J Perinat Neonat Nurs 1999; 13(1): 66-77.

14. Hurst I. Mothers' strategies to meet their needs in the newborn intensive care nursing. J Perinat Neonat Nurs 2001; 15(2): 65-82.

15. Centa $M$ de L, Moreira EC, Godoy MN de, Pinto HR. A experiência vivida pelas famílias de crianças hospitalizadas em uma unidade de terapia intensiva neonatal. Texto-contexto Enf 2004; 13(3): 444-451.

16. Bialoruski MA, Cox CL, Wiggins RD. The relationship between maternal needs and priorities in a neonatal intensive care enviroment. Journal of Advanced Nursing 2002; 37(1): 62-69.

17. Hurst I Vigilant watching over: mothers' ations to safeguard their premature babies in the Newborn Intensive Care Nursing. J Perinat Neonat Nurs 2001; 15(3): 39-57.

18. Holditch-Davis D, Miles M. Mothers' stories about their experience in the NICU. Neonatal Network 2000; 19: 13-21.

19. Shields-Poe D, Pinelli J. Variables associated with parental stress in neonatal intensive care units. Neonatal Network 1997; 16(1): 29-37. 
20. Redshaw M, Harris A, Ingram J. A home form home? Regard parents in policy and practice in neonatal care. Child Health 1994; 2: 7986.

21. Almeida CF, Tachibana M, Ulle TO, Fernandes MA. O vínculo mãebebê prematuro sob o olhar de enfermeiras de UTI Neonatal. Temas sobre desenvolvimento 2003; 12(70): 18-24.

22. Lawhon G. Facilitation of parenting the premature infant within the newborn intensive care unit. J Perinat Neonat Nurs 2002; 16(1): 71-82.

23. Fenwick J, Barclay L, Schmied V. Struggling to mother: a consequence of inihibitive nursing interactions in the Neonatal Nursery. J Perinat Neonat Nurs 2001; 15(2): 49-64.

24. Kamada I. Assistência de enfermagem em unidade de terapia intensiva neonatal. [Tese] Ribeirão Preto(SP): Escola de Enfermagem de Ribeirão Preto da USP; 2002.

25. Walsh F. Fortalecendo a resiliência familiar. São Paulo: ROCA, 2005.

26. Wright LM, Leahey M. Enfermeiras e famílias - um guia para avaliação e intervenção na família. 3.ed. São Paulo: ROCA, 2002.

27. Carter B, McGoldrick M. As mudanças no ciclo de vida familiar - uma estrutura para a terapia familair. In: As mudanças no ciclo de vida familiar: uma estrutura para a terapia familiar. 2.ed. Porto Alegre: Artes Médicas; 1995. cap. 11, p. $206-222$.

28. Elsen I. Cuidado familial: uma proposta inicial de sistematização conceitual. In: Elsen I, Marcon SS, Silva MRS da. O viver em família e sua interface com a saúde e doença. 2.ed. Maringá: Eduem, 2004. cap. 1, p. 19-28. 
29. Althoff CR Delineando uma abordagem teórica sobre o processo de conviver em família. In: Elsen I, Marcon SS, Silva MRS da. O viver em família e sua interface com a saúde e doença. 2.ed. Maringá: Eduem, 2004. cap. 2, p. 29-42.

30. Tubbs CY, Roy KM, Burton LM. Family Ties: constructing family in time in low-income families. Family Process 2005; 44(1): 77-91.

31. Angelo M. Com a família em tempos difícieis: uma perspectiva de enfermagem. [Livre docência] São Paulo (SP): Escola de Enfermagem da Universidade de São Paulo, 1999.

32. Marcon SS. Criando os filhos e construindo maneiras de cuidar. In: In: Elsen I, Marcon SS, Silva MRS da. O viver em família e sua interface com a saúde e doença. 2.ed. Maringá: Eduem, 2004. cap. 3, p. 45-63.

33. Mercer RT. Becoming a mother versus maternal role attainment. J of Nursing Scholarship 2004; 36(3): 226-32.

34. Mercer RT. Nursing support of the processo $f$ becoming a mother. JOGNN 2006; 35(5): 649-51.

35. Warren PL. First time mothers: social support and confidence in infant care. Journal of Advanced Nursing 2005; 50: 479-88.

36. Flacking R, Eewald U, Nyqvist $\mathrm{KH}$, Starrin B. Trustful bonds: a key to "becoming a mother" and to reciprocal breastfeeding. Stories of mothers of very preterm infants at a neonatal unit. Social Science \& Medicine 2005; 62: 70-80.

37. Blumer H. Symbolic interactionism: perspective and method. Englewood Cliffs: Prentice Hall; 1969.

38. Charon JM. Symbolic interactionism: an introduction, an interpretation, an integration. 2.ed. Englewood Cliffs: Prentice Hall; 1985. 
39. Wiklund $L$, Lindholm $L$, Lindström UA. Hermeneutics and narration: a way to deal with qualitative data. Nursing Inquiry 2002; 9(2): 114125.

40. Bleakley A. Stories as data, data as stories: making sense of narrative inquiry in clinical education. Medical education 2005; 39: 534540.

41. Clandinim DJ, Connelly FM. Narrative inquiry: experience and story in qualitative research. San Francisco: Jossey-Bass; 2000.

42. Lieblich A, Tuval-Mashiach R, Zilber T. Narrative research: reading, analysis and interpretation. Thousand Oaks: Sage; 1998; v. 47 Series: Applied social research methods.

43. Barton SS. Narrative inquiry: locating Aboriginal epistemiology in a relational methodology. Journal of Advanced Nursing 2004; 45(5): 51926.

44. Bailey $\mathrm{PH}$, Tilley S. Storytelling and interpretation of meaning in qualitative research. Journal of Advanced Nursing 2002; 38(6): 574-83.

45. Greenhalgh T, Russel J, Swinglehurst D. Narrative methods in quality improvement research. Qual Saf Health Care 2005; 14: 443-49.

46. Minayo MCS. O desafio do conehcimento: pesquisa qualitativa em saúde. 5.ed. São Paulo: Hucitec; 1998.

47. Creswell JW. Qualitative inquiry and research design: choosing among five approaches. 2.ed. Thousand Oaks: Sage; 2007.

48. Frank AW. An overview narrative analysis. Material impresso sem data.

49. Frid I, Öhlen J, Bergbom I. On the use of narrative nursing research. Journal of Advanced Nursing 2000; 32(3): 695-703. 
50. Bell SE. Intensive performances of mothering: a sociological perspective. Qualitative research 2004; 4(1): 45-75.

51. Heermann JA, Wilson ME, Wilhelm PA. Mothers in the NICU: outsider to partner. Pediatric Nursing $2005 ; 31(3): 176-181$.

52. Wigert $H$, Johansson R, Berg M, Hellström AL. Mothers' experience of having their newborn child in a neonatal intensive care unit. Scand $J$ Caring Sci 2006; 20: 35-41.

53. Shin $H$, White-Traut $R$. The conceptual structure of transition to motherhood in the neonatal intensive care unit. Journal of Advanced Nursing 2007; 58(1): 90-98.

54. Mercer RT, Walker LO. A review of nursing interventions to foster becoming a mother. JOGNN 2006; 35(5): 568-582.

55. Jonnaert $\mathrm{P}$, Borght CV. Criar condições para aprender: 0 scoioconstrutivismo na formação do professor. Porto Alegre: Artmed editora; 2002.

56. Vergely B. O sofrimento. Bauru: editora da Universidade do Sagrado Coração; 2000.

57. Nystrom K, Ohrling K. Parenthood experience during the child first year: literature review. J Advanced Nursing 2004; 46(3): 319-330.

58. Lawhon G. Facilitation of parenting the premature infant within the newborn intensive care unit. J Perinat Nurs 2002; 16(1): 71-82.

59. Dixon DM Unifying concepts in parents' experiences with health care providers. J of Family Nursing 1996; 2(2): 111-132.

60. Kirschbaum MS, Knafl KA. Major themes in paret-provider relationships: a comparison of life-threating and chronic illness experience. J of Family Nursing 1996; 2(2): 195-206. 
61. Silveira AO. Buscando segurança para desenvolver suas competências: a experiência de interação da família. [Dissertação] São Paulo (SP): Escola de Enfermagem, 2005.

62. Wright LM. Espiritualidade, sofrimento e doença. Coimbra: Ariadne editora; 2005.

63. Robinson CA. Health care relationships revisited. J of Family Nursing 1996; 2(2): 152-173.

64. Reid T. Maternal identity in preterm birth. J of Child Health Care 2000; 4(1): 23-9. 
Apêndice 


\section{APÊNDICE A \\ TERMO DE CONSENTIMENTO LIVRE E ESCLARECIDO \\ PARTICIPAÇÃO EM PESQUISA CIENTÍFICA}

Meu nome é Monika Wernet, sou aluna do Doutorado em Enfermagem da Escola de Enfermagem da Universidade de São Paulo, sob orientação da Profa. Dra. Margareth Ângelo. Em minha pesquisa de doutoramento busco compreender a experiência da mulher de tornar-se mãe na unidade de terapia intensiva neonatal. Para tanto, estou entrevistando mulheres que aceitem de forma livre a contar-me sobre esta situação.

A entrevista é realizada em um lugar com o mínimo de interferências, o mais privativo possível, de comum acordo entre a pesquisadora e a mulher. Ela será gravada em fita cassete para posteriormente a pesquisadora poder transcrever tudo o que foi dito e analisar estes dados. As fitas das entrevistas permanecerão guardadas com a pesquisadora e, somente ela e sua orientadora terão acesso a seu conteúdo. É garantido sigilo das informações, o anonimato das pessoas entrevistadas, bem como a possibilidade da entrevistada deixar de permitir o uso de seus dados a qualquer momento da pesquisa, mesmo após ter assinado este termo. Para tanto, basta entrar em contato com a pesquisadora através de um dos contatos listados abaixo.

Os resultados obtidos com a pesquisa serão divulgados em eventos, publicações e outras formas de divulgação científica.

PARTICIPAÇÃO NA PESQUISA

$\mathrm{Eu}$, declaro que tomei conhecimento e ciência da pesquisa e dos procedimentos acima descritos relacionados a ela. Concordo em participar da entrevista.

Sei, que em caso de dúvida sobre a pesquisa ou não desejo de continuar cedendo os dados e seu respectivo uso na pesquisa, entrarei em contato com a pesquisadora Monika Wernet por email: mwernet@ig.com.br ou pelo telefone (11) 4701-5356.

Este termo de consentimento possui duas vias, sendo que uma ficará em poder da pesquisada e outra arquivada com a pesquisadora.

São Paulo, de de 200 
Anexo

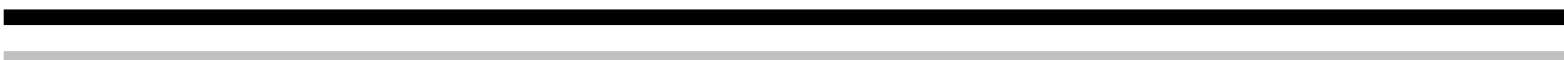


